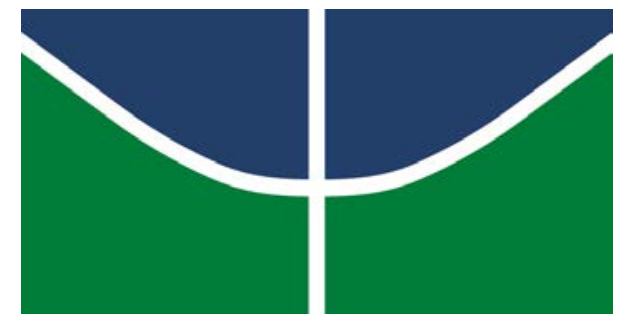

Universidade de Brasília Instituto de Biologia

Departamento de Biologia Celular Pós-graduação em Biologia Microbiana

\title{
MICROBIOLOGIA DO CICLO DO NITROGÊNIO EM SOLOS DO CERRADO
}

ELISA CATÃO CALDEIRA PIRES

Abril de 2016 
Universidade de Brasília

Instituto de Biologia

Departamento de Biologia Celular

Programa de pós-graduação em Biologia Microbiana

\title{
Microbiologia do ciclo do nitrogênio em solos do Cerrado
}

\author{
ELISA CATÃO CALDEIRA PIRES
}

ORIENTADOR: RICARDO H. KRÜGER

Tese de doutorado apresentada ao Programa de Pós-Graduação de Biologia Microbiana do Departamento de Biologia Celular, Instituto de Biologia, Universidade de Brasília

Brasília - DF

Abril de 2016 
Dedico este trabalho àqueles que me motivam todo dia a fazer o melhor de mim: mãe, pai, "rimão". 


\section{Agradecimentos}

Agradeço ao meu orientador, Ricardo Krüger, pelo apoio às nossas idéias de pesquisa, esdrúxulas ou não. Obrigada pela liberdade que você nos dá no laboratório. A meu ver, um local de trabalho com liberdade, cobranças medidas e bom humor ajuda muito na fluidez da pesquisa. Seu humor, que não é fácil de entender, sempre me fez sentir em casa, e algumas das suas ironias ficarão marcadas. Tal como os momentos de geekness, como a explicação do nome de 454 para a plataforma de pirosequenciamento.

Os trabalhos aqui realizados não existiriam sem o financiamento à pesquisa, especificamente pela FAP-DF, CNPq e CAPES. Agradeço especialmente à última, que financiou a minha bolsa de doutorado no país e no exterior.

Agradeço às bancas de qualificação (Professoras Cristine, Mercedes e Sérgio) e de defesa (Professores Cynthia, Mercedes, Alexandre e Helson) desta tese que auxiliaram na discussão e no refinamento deste documento.

Agradeço também aos professores colaboradores que fizeram parte mais diretamente das pesquisas apresentadas nesta tese: Gabriela Nardoto, Mercedes Bustamante e Jim Prosser.

Entretanto, teria sido mais difícil de realizar esta tese se eu não tivesse ao meu lado parceiros de bancada e de computador: Fabyano, Ju, Re(nata) e Re(gina). E não tão diretamente relacionados ao meu dia-a-dia, mas também parte do grupo, agradeço à Débora, Paula e Samuel. E um especial obrigado à minha amiga que me chama de “orientadora -mirim", Helena Magaldi, que me ajudou muito na leitura e correção dos meus textos.

Tenho um agradecimento especial a fazer ao Fabyano, parceiro científico, amigo, colega, nosso Thor do Cerrado. Aquele que me livrou de ataque de cupim e potencial ataque de suçuarana-pesquisador (?). Agradeço imensamente a oportunidade de termos trabalhado juntos. E espero que prospere o nosso plano de continuarmos colaborando em projetos futuros.

A pesquisa do sisbiota só foi possível porque conseguimos (Eu e Fabyano) reunir mão-deobra amiga e voluntária para as várias coletas: Renata, Amanda, Lucas, Matias, Hugo e Huguinho.

De mesma forma, consegui carregar muita gente para campo para coletar solo na Fazenda Tabapuã dos Pirineus. Agradeço especialmente ao Marciano, que esteve em todas as coletas e me auxiliou com rigor nos meus primeiros experimentos de PCR em tempo real. Agradeço também à Cecília Kosmann, à Carol Benévolo, ao Lucas Pimenta, e novamente à Ju e ao Fabyano.

Um agradecimento especial deve ser feito ao Fabiano Nardoto, dono da Fazenda Tabapuã dos Pirineus. Não só permitiu o acesso livre à fazenda para os diferentes tempos de coleta, mas também nos proveu informações sobre a fazenda e a plantação de soja e de milho. 
Quanto ao meu período de sanduíche na Escócia. Agradeço novamente ao Krüger, que me apoiou na minha escolha de ir lá bem para longe onde parcerias ainda não tinham sido formadas com o grupo.

Foi um sonho realizado trabalhar com o pesquisador que é Jim Prosser. Agradeço a ele pela oportunidade de trabalhar no seu laboratório, pelo acesso à infra-estrutura e às discussões científicas de alto nível. Agradeço ainda por me ensinar algumas palavras com o sotaque de Liverpool, e manter sempre um nível de descontração e ao mesmo tempo crítico nas reuniões.

Agradeço especialmente àquela que se tornou minha supervisora/colaboradora de pesquisa e amiga em todos os momentos, Cécile Thion e também à grande amiga Jessica Poirel. A bem dizer a experiência foi ótima com todos. $O$ trabalho foi muito mais divertido por ser ao lado da lassie Heather Richmond, que falava comigo em bom escocês. As discussões geeks foram mais divertidas por causa da Eva Weber, e o cultivo de AOA e AOB só foi bemsucedido por causa da ajuda da Jenna Ross, que me ajudou a entender várias palavras do sotaque escocês. Mas tenho que agradecer a todos do grupo: Graeme Nicol, Cécile GR, Laura Lehtorvita-Morley, Linda Hink, Heiko Nacke, Angus Mei e Marcus Bello. Agradeço também ao Michael e ao David pelas análises de FIA e à Annette e ao Professor Paul Hadley por me ensinarem e permitirem o uso da máquina de mensuração de potencial de água no solo.

Agradeço também àqueles que, fora do laboratório alegraram os meus dias, mesmo aqueles mais cinzas em "Aberdream": Chiara, Lucas, Guilhem, Giulia, Ana, Babi e Mateus e Sarah. E Patricia Morcillo e Deboshree Gosh, melhores roommates ever. Também à Elitsa e à Gabi.

Por que uma tese é um trabalho constante, considerando que a nossa (a minha pelo menos) cabeça não pára um segundo de pensar ciência, agradeço ao suporte fora da Universidade. Mãe, pai, vocês me inspiram pelas carreiras que desenvolveram. Observo vocês para poder reproduzir na minha carreira um pouco dessa excelência que vocês têm. Obrigada ainda pelo apoio diferencial que vocês promovem na minha vida pessoal e profissional. Fran, você sabe que é a pessoa mais importante da minha vida e é aquele que sabe me alegrar e me escutar nas crises e nas alegrias.

Ainda fora do meio acadêmico, agradeço o suporte que recebo das minhas melhores amigas Renata, Rapha, Ju, Carol, Cecília e Sorriso.

At last but not least, na ciência e fora, agradeço ao meu chéri Nicolas Gallois que me ajuda a revisar quase tudo o que eu escrevo (em inglês), que discute comigo os meus dados, que está sempre ao meu lado e que me apoiou nas minhas escolhas, nas minhas loucuras e alegrias e na minha ausência durante a escrita final. 


\section{Resumo Geral}

A interação entre as variáveis do solo e a microbiota influencia os processos que ocorrem no solo, tanto que, em ambientes terrestres o $\mathrm{N}$ é reciclado primariamente pela microbiota. No ciclo do N, a nitrificação é a etapa em que nitrato se torna disponível no solo para as plantas, mas também $\mathrm{N}$ é perdido por lixiviação de nitrato ou pela emissão de gases nitrogenados. Entretanto, as mudanças climáticas, a modificação do uso da terra e a aplicação de fertilizantes nitrogenados veem alterando a dinâmica de N. Um especial interesse é direcionado à maior savana na América do Sul, o bioma tropical sazonal seco que é o Cerrado, cuja paisagem vem sendo alterada pela agricultura. Fazendo uso da técnica de metagenômica, os atributos funcionais da microbiota do solo do Cerrado quanto ao ciclo do $\mathrm{N}$ foram comparados entre dois parques de conservação do bioma, distantes $500 \mathrm{~km}$ entre si, com variação na textura e no conteúdo de água do solo. Os tipos de vegetação amostradas dentro de cada parque mascararam os efeitos de altitude e distância entre os parques, e todas as amostras apresentaram uma maior abundância de genes para assimilação de amônia e amonificação. Isso corrobora a literatura encontrada sobre o metabolismo de amônia como forma principal de $\mathrm{N}$ no Cerrado. Em particular, o Campo limpo alagado, presente somente em um dos parques, apresentou a maior abundância de genes fixadores de nitrogênio. Ainda, foram detectados genes para denitrificação, mas somente dois hits foram observados para nitrificação. Sucessivamente, foi acessado o impacto do manejo do solo sobre a abundância de Archaea e Bacteria oxidantes de amônia por quantificação do gene marcador amoA ao longo do cultivo da soja no bioma Cerrado. A análise molecular, tal como as técnicas clássicas e de isótopos mostraram um maior conteúdo de $\mathrm{C}$ orgânico e de $\mathrm{NH}_{4}{ }^{+}-\mathrm{N}$ no pousio em comparação à área nativa de reserva legal adjacente ao plantio da soja. De mesma forma, observou-se um aumento na abundância de oxidantes de amônia e da taxa de nitrificação no solo agrícola em comparação à área nativa, com a menor razão amônia/nitrato observada no solo após revolvimento. A abundância de $\mathrm{AOB}$ apresentou correlação com o aumento de $\mathrm{pH}$ ao longo do cultivo da soja. Experimentos seguintes testaram o efeito de água e de $\mathrm{pH}$ em microcosmos contendo solo do Cerrado, tal como a possível inibição de nitrificação em slurries contendo uma mistura de solo do Cerrado com um solo agrícola (Craibstone) com reconhecida atividade de oxidação de amônia. No entanto, o acúmulo de $\mathrm{NO}_{3}^{-}$estava abaixo do nível de detecção na maior parte das amostras, tanto naquelas com aumento no teor gravimétrico de água ou com aumento de $\mathrm{pH}$, independente da alta concentração de amônia. A nitrificação não foi inibida nas misturas de slurries incubadas, e, ainda, após 21 
dias de incubação foi possível detectar transcritos de amoA de AOA no slurry de solo de Cerrado. Os perfis de DGGE mostraram um maior número de bandas de AOA amoA nos slurries de Craibstone e das misturas dos dois solos, do que o perfil observado nos slurries incubados somente com solo do Cerrado. Considerando o exposto acima, este foi o primeiro trabalho apresentado sobre o metabolismo de $\mathrm{N}$ e mais especificamente sobre a oxidação de amônia, utilizando dados de metagenomas e de PCR em tempo real. A baixa detecção de nitrato nas amostras de campo e de incubações em laboratório sugerem que algum outro mecanismo ocorre nos solos do bioma Cerrado no sentido de preservação de $\mathrm{N}$ inorgânico preferencialmente na forma de amônia. Sugerimos que a nitrificação depende da presença de oxidantes de amônia, mas também da composição da comunidade microbiana, sendo que a sua diversidade afeta a dinâmica de $\mathrm{N}$ no solo. Provavelmente condições abióticas e bióticas influenciam na limitação de crescimento da comunidade de oxidantes de amônia autotróficos no Cerrado. Por exemplo a competição por amônia entre esses oxidantes autotróficos e plantas ou com microorganismos heterotróficos. Ainda a redução dissimilatória de nitrato a amônia ou a imobilização abiótica de nitrato podem influenciar o desenvolvimento daquela comunidade 


\section{General abstract}

Interactions between soil characteristics and microbiota influence the processes in soil ecosystem, as the terrestrial $\mathrm{N}$ is primarily cycled by the microbiota. In the $\mathrm{N}$ cycle, nitrification enables plants' access to nitrate, although $\mathrm{N}$ can be lost through nitrate leaching, or $\mathrm{N}$ trace gas emission. These $\mathrm{N}$ dynamics are being disturbed by climate change, land use modification and the employment of nitrogenous fertilizers. A special interest goes to the largest savanna in South America, the seasonally dry Cerrado biome, where agriculture is changing the biome landscape. Shotgun metagenomics was used to compare the functional attributes of $\mathrm{N}$ cycling from the soil microbiota present in two conservation parks of the Cerrado biome, $500 \mathrm{~km}$ distant from each other, with varying soil texture and water content. Types of vegetation sampled within each park masked the altitude and distance effects, but all samples showed higher abundance of genes for assimilation of ammonia and ammonification. This corroborates Cerrado literature of ammonia as the main soil $\mathrm{N}$ form. In addition, a flooded grassland presented the highest abundance of $\mathrm{N}$ fixation genes. Despite the detection of denitrification genes, only two hits for the nitrification process were described. Subsequently, we assessed the impact of soil management on the abundance of Archaea ( $A O A$ ) and Bacteria ( $A O B$ ) ammonia oxidizers by quantification of the marker gene $(a m o A)$ during different stages of soybean cultivation within the Cerrado. Molecular analysis and classic and isotope techniques exhibited higher content of organic $C$ and $\mathrm{NH}_{4}{ }^{+}-\mathrm{N}$ during fallow than in the adjacent undisturbed field, and an increase in ammonia oxidizers abundance and nitrification rates in the agricultural soil than in the undisturbed site, with the lowest ammonium/nitrate ratio in tilled soil. AOB abundance was correlated with the increase in $\mathrm{pH}$ during soybean cultivation. Further experiments tested the effect of moisture and $\mathrm{pH}$ in microcosms containing Cerrado soil, and the possible nitrification inhibition in slurries assembled with a mixture of Cerrado and agricultural soil known for actively oxidizing ammonia (Craibstone soil). Nevertheless, very little $\mathrm{NO}_{3}{ }^{-}$accumulation was observed in Cerrado microcosms with either increasing moisture or $\mathrm{pH}$, despite high ammonia concentration. Nitrification was not inhibited in the mixed soil slurries, and after 21 days it was possible to detect the activity of $A O A$ with the quantification of amoA transcripts. Moreover, DGGE profiles showed a higher number of AOA amoA gene in the Craibstone-only slurries and similar to the mixed slurries, but lower in the Cerrado-only slurries. This was the first assessment of the $\mathrm{N}$ metabolism with metagenomic data and qPCR for ammonia oxidation in the Cerrado. However, the little accumulation of $\mathrm{NO}_{3}{ }^{-}$in the field soils or in the treated microcosms or slurries advocates that some other mechanism 
occurs in this ecosystem to preserve inorganic $\mathrm{N}$ preferentially in the $\mathrm{NH}_{3}$ form. Taken these findings together, it is likely that not only the presence of ammonia oxidizers is fundamental for nitrification to occur, but that the microbial community composition and diversity affects the direction in which $\mathrm{N}$ process occur in soil. Most possibly there is a correlation between abiotic and biotic conditions that limits the abundance of autotrophic ammonia oxidizers, as for example the competition for $\mathrm{NH}_{4}{ }^{+}$by plants or heterotrophic microbes or through dissimilatory reduction of $\mathrm{NO}_{3}{ }^{-}$to $\mathrm{NH}_{4}{ }^{+}$. 


\section{General Index}

LEGENDS OF FIGURES AND TABLES

MOTIVAÇÃO

OBJETIVOS E HIPÓTESES

ORGANIZAÇÃO DE CAPÍTULOS

CHAPTER 1 - N CYCLE, NITRIFICATION AND THE CERRADO BIOME: LITERATURE REVIEW 16

$\begin{array}{ll}\text { NITRIFICATION } & 17\end{array}$

$\begin{array}{lr}\text { HETEROTROPHIC NITRIFICATION } & 19\end{array}$

$\begin{array}{ll}\text { DENITRIFICATION } & 20\end{array}$

DENITRIFIERS GUILDS AND N TRACE GASES EMISSION

N FIXATION AND OTHER SOURCES OF $N$

LAND USE IMPACT ON MICROBIAL COMMUNITIES

CHAPTER 2 - DISTRIBUTION OF MICROBIAL COMMUNITIES IN TWO CERRADO CONSERVATION PARKS WITH A METAGENOMICS APPROACH, WITH SPECIAL FOCUS ON THE N METABOLISM 25

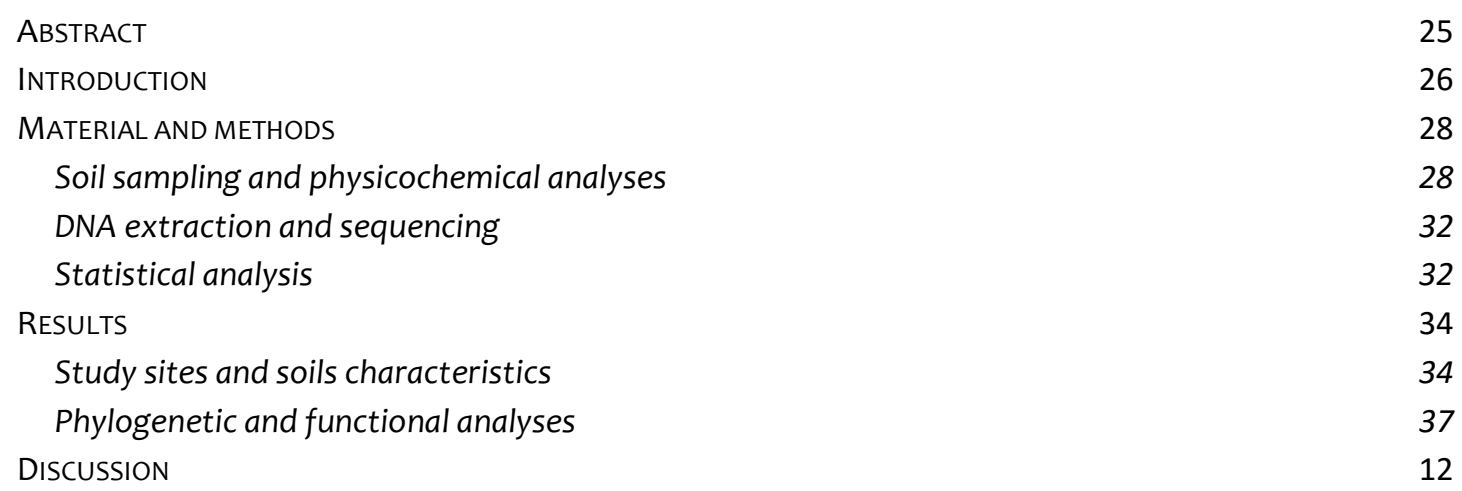

CHAPTER 3 - SHORT-TERM IMPACT OF SOYBEAN MANAGEMENT ON AMMONIA OXIDIZERS IN A BRAZILIAN SAVANNA UNDER RESTORATION AS REVEALED BY COUPLING DIFFERENT TECHNIQUES

$\begin{array}{ll}\text { ABSTRACT } & 11\end{array}$

INTRODUCTION 12

MATERIALS AND METHODS 14

$\begin{array}{ll}\text { Study sites and soil characteristics } & 14\end{array}$

Isotope analysis 18

DNA extraction 18

Real-time PCR 18

$\begin{array}{lr}\text { Statistical Analysis } & 19\end{array}$

RESULTS 20

Description of study sites and soil physicochemical characteristics 20

Ammonium and nitrate concentrations and soil $\delta^{15} \mathrm{~N} \quad 21$

Abundance of archaeal and bacterial amoA genes $\quad 25$

DISCUSSION 28

CHAPTER 4 - AMMONIA OXIDIZERS IN A NON-NITRIFYING BRAZILIAN SAVANNA SOIL 32

$\begin{array}{ll}\text { ABSTRACT } & 32\end{array}$

$\begin{array}{ll}\text { INTRODUCTION } & 33\end{array}$ 
$\begin{array}{lr}\text { MATERIALS AND METHODS } & 35\end{array}$

Soil sampling $\quad 35$

Cultures with or w/o soil aqueous extracts

Soil incubation in slurries $\quad 36$

Soil incubation in microcosms

Soil physicochemical analyses

$\begin{array}{ll}\text { Molecular analysis } & 37\end{array}$

Statistical analysis $\quad 38$

$\begin{array}{ll}\text { RESULTS } & 40\end{array}$

Effects of soil extracts on ammonia oxidizer cultures 40

Effects of Campo sujo soil on nitrification in Craibstone soil 41

Effects of soil pH and moisture content

$\begin{array}{ll}\text { DISCUSSION } & 47\end{array}$

CHAPTER 5 - ABIOTIC AND BIOTIC FACTORS THAT AFFECT AMMONIA OXIDIZERS AND THEREFORE $\begin{array}{lr}\text { NITRIFICATION: FINAL DISCUSSION } & 50\end{array}$

$\begin{array}{ll}\mathrm{PH} & 51\end{array}$

$\begin{array}{ll}\mathrm{NH}_{4}{ }^{+} & 53\end{array}$

$\begin{array}{ll}\text { HETEROTROPHIC NITRIFICATION } & 54\end{array}$

$\begin{array}{lr}\text { INHIBITION OF NITRIFICATION } & 55\end{array}$

FE

SOIL TEXTURE AND WATER CONTENTS

CERRADO VEGETATION COVER AND LAND USE CHANGE $\quad 60$

$\begin{array}{ll}\text { FINAL CONSIDERATIONS AND NEW HYPOTHESES } & 61\end{array}$

CAPÍTULO 6 - CONCLUSÕES E PERSPECTIVAS 66

$\begin{array}{lr}\text { REFERENCES } & 67\end{array}$ 


\section{Legends of figures and tables}

Figure 1. $\mathrm{N}$ cycle processes in oxic and anoxic environments. 18

Figure 2. Photographs of the sites sample in the two parks.

Figure 3. Boxplots on soils (A) $\mathrm{NH}_{4}{ }^{+}-\mathrm{N}$ and (B) $\mathrm{NO}_{3}{ }^{-}-\mathrm{N}$ concentration, (C) $\mathrm{pH}$ and (D) water soil content.

Figure 4. Soil physicochemical variables in the two parks and their sites.

Figure 5. Principal component analysis (PCA) constructed with the relative abundance of annotated genes for (A) phylogenetic assignment of phyla and (B) subsystems functional 38

Figure 6. Bar plots for the relative abundance of SEED subsystems according to each site $\times$ park. (A) Most abundant SEED subsystems, (B) less abundant SEED subsystems.

Figure 7. Schematic representation of the $\mathrm{N}$ cycle according to the SEED subsystems annotated genes performed with e!Sankey 2

Figure 8. Boxplots of soils (A) ammonia assimilation, (B) nitrate and nitrite ammonification, (C) nitrogen fixation, (D) dissimilatory nitrite reductase, (E) denitrification, (F) nitrosative stress.

Figure 9. (A) Representation of the map (B) sampled parks PESA and PNCV marked in the Google Earth photography (C) Module experimental design scheme

Figure 10. Gravimetric soil water content.

Figure 11. Satellite view and photographs of the sample site on the Tabapuã dos Pireneus Farm.

Figure 12. Principal component analysis (PCA) of soil physicochemical properties

Figure 13. One-way ANOVA tests on soil N values, with Tukey-Kramer post hoc tests to compare group means ( $R$ with the ggplot2 package).

Figure 14. Relationship between soil $\delta^{13} \mathrm{C}$ and $\delta^{15} \mathrm{~N}$ in \%. Each point represents samples from each soil condition, marked with different symbols.

Figure 15. Changes in (A) $A O A$ amoA gene abundance, (B) $A O B$ amoA gene abundance, (C) $A O A: A O B$ amoA gene abundance ratio, and (D) archaeal 16S rRNA:amoA gene abundance ratio.

Figure 16. Graphical representation of the three experimental designs.

Figure 17. Specific growth rate calculated during exponential nitrite production batch cultures of the soil $\mathrm{C} 13$ and four soil $\mathrm{AOB}$ 
Figure 18. Changes in inorganic $\mathrm{N}$ concentration during incubation of slurries of Craibstone and Campo sujo soils and mixtures of these soils.

Figure 19. Changes in (A) $A O A$ amo $A$ gene abundance, (B) $A O B$ amoA gene abundance, (C) $A O A: A O B$ amoA gene abundance ratio and (D) AOA amoA transcript abundance during incubation of slurries of Craibstone and Campo sujo soils and mixtures of these soils........ 44

Figure 20. DGGE analysis of partial amoA gene products from triplicate soil slurries of $(G)$ Campo sujo-only, (CG) 1:1 Campo sujo: Craibstone mixed and (C) Craibstone-only 45

Figure 21. Changes in (A) $\left(\mathrm{NH}_{4}{ }^{+}-\mathrm{N}+\mathrm{NO}_{3}{ }^{-} \mathrm{N}\right)$ and (B) $\mathrm{NO}_{3}{ }^{-} \mathrm{N}$ during incubation of microcosms containing Campo sujo or Craibstone soil after manipulation of $\mathrm{pH}$ and moisture content. 46

Figure 22. Interaction between abiotic and biotic factors and their effect on the $\mathrm{N}$ cycle processes

Table 1. Physicochemical variables (mean \pm SE) of the sampled sites in PNCV 29

Table 2. Physicochemical variables (mean \pm SE) of the sampled sites in the PESA 30

Table 3. Coordinates and altitude of each sampled site 18

Table 4. Number of sequences for each metagenome, their identification and the number of reads that passed QC, that were annotated and to the $\mathrm{N}$ metabolism.

Table 5. Soil physicochemical properties for each one of the replicates in all treatments ... 17 


\section{Motivação}

Micro-organismos aprovisionam diversos serviços ecossistêmicos, tais como a reciclagem de nutrientes e a decomposição de matéria orgânica, a reciclagem de dejetos e o controle biológico de pestes. Na economia mundial atual, esses serviços representam um terço da contribuição anual dos serviços ecossistêmicos terrestres, significando uma média global estimada de 1,6 trilhões de dólares por ano. Além disso, a interação entre microorganismos e plantas, especialmente na rizosfera, é responsável pela nutrição e saúde das plantas, que dependem de reações catalisadas pelos micro-organismos no solo. Consequentemente, o crescimento populacional mundial depende do fornecimento de comida pela agricultura e pecuária, por sua vez condicionado à reciclagem de nutrientes por micro-organismos no solo.

Todavia, o objetivo dos micro-organismos é o de obter energia para seu próprio metabolismo ou produção de biomassa. Por sua vez, se o substrato é provido em excesso no ambiente, uma maior concentração de produtos será liberada e não incorporada à biomassa microbiana (e de plantas). Por exemplo, o uso de fertilizantes nitrogenados em excesso na agricultura pode potencialmente levar ao aumento de emissão de gases nitrogenados causadores do efeito estufa $\left(\mathrm{N}_{2} \mathrm{O}\right)$, e também às perdas de nitrato que levam à contaminação de cursos de água.

A aquisição de energia em solos não é tarefa simples: formas de vida diferentes competem para a viabilidade de substratos, ou também colaboram para a troca de substrato/produto. Essa competição acontece a todo momento, em micro hotspots do solo; uma batalha entre plantas e micro-organismos e entre diferentes micro-organismos.

No último dezembro, na COP 21, a maior parte dos países concordou que devem ser tomadas ações para a redução do aquecimento global, que está notadamente associado à emissão de gases de efeito estufa. No entanto, os micro-organismos não foram protagonistas nas discussões da reunião acima citada, apesar de estarem diretamente relacionados à capacidade de um ambiente de ser fonte ou captador dos gases de efeito estufa. Nesse contexto, a ecologia microbiana de solo tem como foco a identificação de genes que controlam especificamente as funções relativas à emissão desses gases ou outras vias metabólicas da ciclagem de nutrientes. Desta forma é possível monitorar as mudanças no ecossistema e aquelas relativas aos serviços ecossistêmicos providos pelos micro-organismos. 
Mudanças climáticas, pluviometria e o regime de fogo devem ser considerados nos estudos da savana tropical sazonalmente seca no Brasil Central. Esta, o Cerrado, é a savana de maior biodiversidade, e em grande parte endêmica. Ainda mais, sua área está em constante modificação devido à fronteira agrícola, envolvida na produção de commodities brasileiras.

Tal como referido anteriormente, as comunidades microbianas são os atores das transformações bioquímicas que ocorrem nos solos, e as técnicas moleculares são usadas para descrever e compreender as modificações que ocorrem nas comunidades microbianas de acordo com as mudanças no ambiente amostrado. Nesse contexto, e para nosso conhecimento, esta tese é o primeiro trabalho que considera a variação dos grupos funcionais relacionados à ciclagem do $\mathrm{N}$ no Cerrado, medida pela abundância de genes microbianos no solo. 


\begin{tabular}{|c|c|}
\hline & Objetivos \\
\hline \multirow[t]{10}{*}{ Gerais } & Descrever a microbiota do solo \\
\hline & do Cerrado nativo e \\
\hline & $\begin{array}{l}\text { convertido à plantação da soja, } \\
\text { fazendo uso de técnicas } \\
\text { moleculares e com foco no } \\
\text { metabolismo do } \mathrm{N}\end{array}$ \\
\hline & $\begin{array}{l}\text { Estudar as baixas taxas de } \\
\text { nitrificação líquida observadas }\end{array}$ \\
\hline & $\begin{array}{l}\text { nesses solos ao analisar a } \\
\text { comunidade microbiana }\end{array}$ \\
\hline & $\begin{array}{l}\text { Analisar a relação entre } \\
\text { biodiversidade microbiana e a }\end{array}$ \\
\hline & provisão de serviços \\
\hline & ecossistêmicos como a \\
\hline & ciclagem de nutrientes \\
\hline & $\begin{array}{l}\text { Determinar o impacto da } \\
\text { agricultura na abundância de } \\
\text { oxidantes de amônia e seu } \\
\text { funcionamento }\end{array}$ \\
\hline
\end{tabular}

Específicos Capítulo 2 Analisar a diversidade taxonômica e funcional dos micro-organismos do solo do Cerrado, usando dados de metagenômica

Identificar genes dos grupos microbianos responsáveis pelo metabolismo do $\mathrm{N}$

Estabelecer a correlação entre a abundância relativa dos genes do metabolismo do $\mathrm{N}$ e as características do solo e da vegetação entre e dentro dos parques de conservação

Capítulo 3 Investigar a variação temporal e espacial da abundância de archaeas e bactérias oxidantes de amônia por PCR quantitativa ao longo do cultivo da soja no bioma Cerrado

Elucidar as variáveis físicoquímicas que explicam a mudança na abundância dos oxidantes de amônia
Hipóteses

A comunidade de oxidantes de amônia será menos abundante nos solos do Cerrado, considerando as baixas taxas de nitrificação

A abundância relativa dos genes relativos ao ciclo do $\mathrm{N}$ irá variar conforme as qualidades físico-químicas dos solos amostrados

O solo agrícola apresentará uma estrutura diferente da comunidade de oxidantes de amônia em relação ao solo nativo

A comunidade microbiana irá diferir de acordo com a distância biogeográfica e as características físico-químicas dentro e entre os parques de conservação

A abundância dos genes anotados para o metabolismo do $\mathrm{N}$ irá refletir a razão $\mathrm{C}: \mathrm{N}$, o $\mathrm{pH}$, o teor gravimétrico de água e os conteúdos de $\mathrm{N}$ e $\mathrm{C}$ dos solos amostrados dentro e entre os parques

A razão entre archaeas e bactérias oxidantes de amônia irá modificar ao longo do cultivo da soja devido ao aumento do $\mathrm{pH}$ e à adição de fertilizantes nitrogenados

A comunidade de archaeas oxidantes de amônia será maior em número que aquela de bactérias no solo nativo de Campo sujo e na área de manejo da soja durante o pousio devido ao $\mathrm{pH}$ mais ácido e à provisão de $\mathrm{NH}_{4}{ }^{+}$ principalmente por mineralização 
Capítulo 4 Incubar solos em microcosmos para testar o efeito da água e do $\mathrm{pH}$ na habilidade do solo de acumular nitrato

Testar o potencial biológico de inibição para nitrificação em solos do Cerrado contra um solo exótico agrícola com alta capacidade de nitrificar
Exsudatos naturais de algumas plantas estarão relacionado à potencial inibição biológica e, portanto, à redução do crescimento e atividade de oxidantes de amônia

O baixo teor gravimétrico de água e o baixo $\mathrm{pH}$ dos solos do Cerrado limitará o crescimento e atividade de oxidantes de amônia 


\section{Organização de capítulos}

Capítulo 1 - Introdução apresenta a revisão da literatura quanto ao conhecimento dos processos enzimáticos microbianos envolvidos na ciclagem de nitrogênio em solos, com uma perspectiva direcionada ao bioma Cerrado, que é o foco desta tese

Capítulo 2 - Análise metagenômica da microbiota do solo de Cerrado nativo, com especialmente interesse na abundância relativa de genes anotados para o metabolismo do nitrogênio

Capítulo 3 - Cultivo de soja na Fazenda Tabapuã dos Pirineus pela primeira vez foi escolhido para investigar o efeito a curto prazo do manejo agrícola sobre a abundância de archaeas e bactérias oxidantes de amônia

Capítulo 4 - Limitação da oxidação de amônia em solos do Cerrado foi avaliada em microcosmos e culturas puras para testar o efeito da água, $\mathrm{pH}$ e potenciais inibidores biológicos produzidos por plantas sobre a nitrificação

Capítulo 5 - Discussão com o objetivo de retornar aos principais pontos apresentados nos capítulos anteriores e também estabelecer novas considerações sobre regulações bióticas e abióticasdo ciclo do nitrogênio e, mais especificamente, da nitrificação, que ocorrem nos solos

Capítulo 6 - Conclusão 


\section{Chapter 1 - $\mathbf{N}$ cycle, nitrification and the Cerrado biome: literature review $^{1}$}

"We became scientists because we are curious - we are driven to solve the puzzles that nature presents." Joshua Schimel

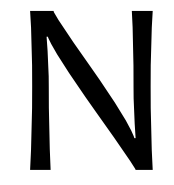
itrogen cycling is mainly controlled by microorganisms in a multitude of processes and regulations. Advances in research presents novelties that were sometimes anticipated based in $\mathrm{N}$ thermodynamics. For example, just recently it has been discovered the "comammonas" process, which is the ability of ammonia oxidation to nitrite and subsequently to nitrate in a same organism; metabolism predicted by the higher gain of energy when are substrate- and spatial-limited (Daims et al., 2015; van Kessel et al., 2015).

Plants and microorganisms can assimilate $\mathrm{N}$ in the form of ammonia, nitrate, and sometimes organic $\mathrm{N}$, or $\mathrm{N}_{2}$ for a few Bacteria and Archaea. $\mathrm{N}_{2}$ enters the lithosphere and is biologically transformed to $\mathrm{NH}_{4}{ }^{+}$. In turn, $\mathrm{NO}_{3}{ }^{-}$is made available by the dissimilatory process of ammonia oxidation by autotrophic Archaea, Bacteria or heterotrophic Bacteria and Fungi. Microorganisms compete within themselves and with plants to use the $\mathrm{NO}_{3}^{-}$available in soil, which can be either assimilated or used as electron donor. The balance of processes

\footnotetext{
${ }^{1}$ A modified version of this thesis introduction and discussion will be submitted as a review on the $\mathrm{N}$ cycle of the Cerrado soils.
} 
and the soil conditions determines the availability of $\mathrm{N}$ returning to $\mathrm{NH}_{4}{ }^{+}$or being completely reduced to $\mathrm{N}_{2}$.

$\mathrm{N}$ is essential to primary productivity and, in nature, is mainly dependent on biological nitrogen fixation, which produces reactive $\mathrm{N}$. On the other hand, the non-natural chemical conversion of atmospheric $\mathrm{N}_{2}$ to $\mathrm{NH}_{3}$ in the Haber-Bosch process, increased the reactive $\mathrm{N}$ concentration in the environment, presenting consequences due to $\mathrm{N}$ loss to the atmosphere as $\mathrm{N}$ trace gases, or to water courses as nitrate produced during nitrification (Galloway and Cowling, 2002).

\section{Nitrification}

Nitrification can be measured as gross or net rates; the first is quantified by the assimilatory or dissimilatory processes calculated for example by the ${ }^{15} \mathrm{~N}$ pool dilution methods (Davidson et al., 1991). Net nitrification is obtained by the variation of $\mathrm{NO}_{3}^{-}-\mathrm{N}$ concentration in incubated soil (either in laboratory or field conditions) during an established period of time. However, only the first method can assess if ${ }^{15} \mathrm{NO}_{3}^{-}$pool is diluted with ${ }^{14} \mathrm{NO}_{3}^{-}$produced by autotrophic nitrifiers from ${ }^{14} \mathrm{NH}_{4}{ }^{+}$or by heterotrophic organisms from organic ${ }^{14} \mathrm{~N}$ (Davidson et al., 1991). Net nitrification in native undisturbed Cerrado soils is low and sometimes undetectable. These soils present high $\mathrm{NH}_{4}{ }^{+}-\mathrm{N}^{-} \mathrm{NO}_{3}{ }^{-} \mathrm{N}$ ratio (Nardoto and Bustamante, 2003) and insignificant $\mathrm{N}_{2} \mathrm{O}$ emissions (Cruvinel et al., 2011; Pinto et al., 2006; Pinto et al., 2002). Thus, the investigation of nitrification in the Cerrado biome is of particular interest for its $\mathrm{N}$-limitation (Araujo et al., 2012), with higher rate of $\mathrm{N}$ immobilization than mineralization (Nardoto and Bustamante, 2003), which leads to a need of fertilizers and liming when land use is changed for agriculture.

Cerrado is the savanna of Central Brazil and, as such has a plant cover distribution dependent on the interaction between water and nutrient availability (Medina, 1987) in (Bustamante et al., 2006), with weathered soils with low nutrient availability (Reatto et al., 1998). The Cerrado presents a range of herbaceous and tree/shrub strata from grassland to savanna and forest formations, that are related to the type of soil (Reatto et al., 1998), which may present varying contents of nitrogen according to the tree-shrub layer density, the fire regime and the land use change (Bustamante et al., 2006).

Bustamante et al. (2006) reviewed $\mathrm{N}$ concentration and $\mathrm{N}$ dynamic in ecosystem compartments for the tropical savannas, but it remains to be discussed the microorganisms 
associated with $\mathrm{N}$ metabolism. Microbial ecology has been used in the last couple of decades to improve knowledge on biogeochemical processes in the environment. The presence of genes can be directly measured by PCR quantification or the taxonomic categories can be assigned through sequencing (Figure 1). Metagenomics' studies are primer-independent thus allowing a more holistic description of genes abundance in the ecosystem. Nevertheless, the current culture-independent methods depend on database search and a great number of genes is still unclassified. Therefore, classical microbiology approach with isolated microorganisms is complementary.

Nitrification involves two groups of specialized organisms phylogenetically unrelated: the ammonia-oxidizers and the nitrite-oxidizers. The oxidation of ammonia is often the focus of research, because it is the limiting-step for nitrification to occur. However, and as mentioned above, in the end of 2015 two groups were able to identify an organism, "Candidatus Nitrospira inopinata able to perform the complete oxidation of ammonia to nitrate, isolated from a biofilm in a pipe under hot water flow (Daims et al., 2015) and from an ammonium-oxidizing biofilm from an aquaculture system filter (van Kessel et al., 2015).

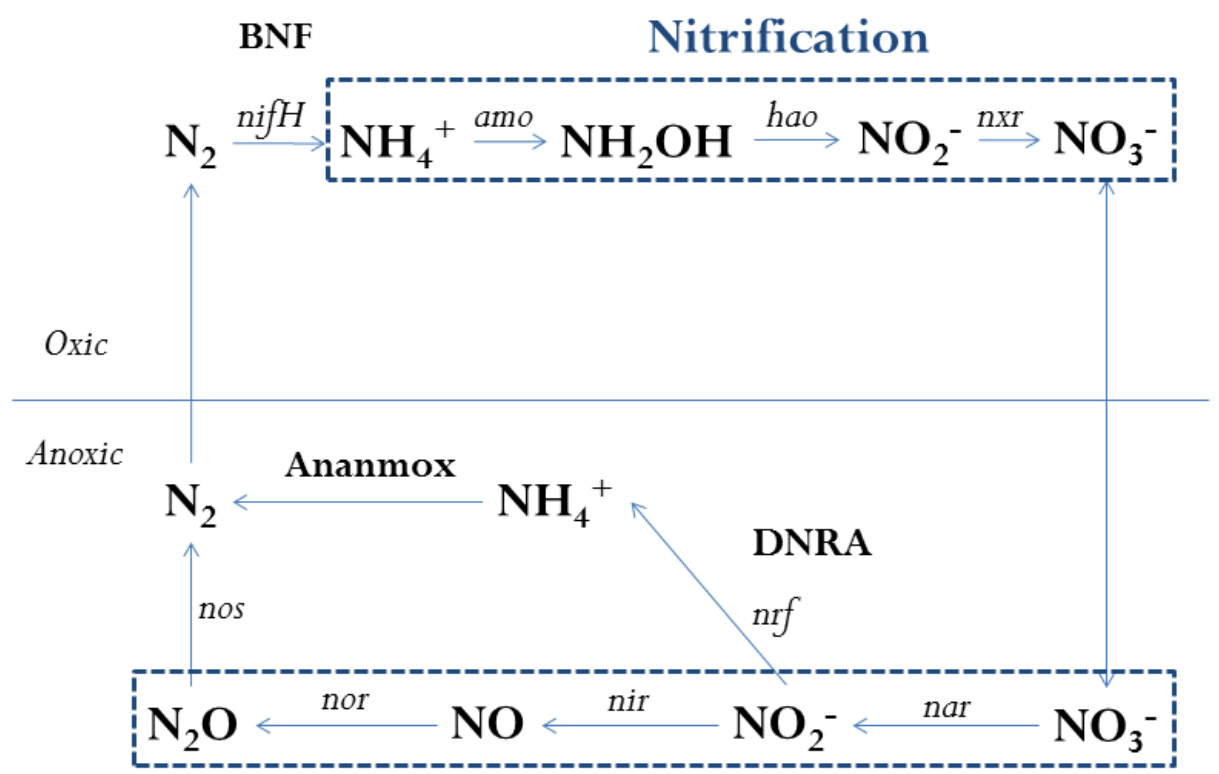

Denitrification

Figure 1. $\mathrm{N}$ cycle processes in oxic and anoxic environments. Special highlight to nitrification and denitrification. In italic genes often used to quantify these processes BNF: Biological nitrogen fixation. DNRA: dissimilatory nitrate reduction to ammonium. Ananmox: anaerobic oxidation of ammonia. 
The presence of ammonia oxidizers is quantified by the amoA gene coding for the subunit $A$ of the enzyme ammonia monooxygenase, and it is catalyzed by autotrophic Bacteria (AOB) - Nitrosomonas ( $\beta$-proteobacteria), Nitrosospira ( $\beta$-proteobacteria) (Kowalchuk and Stephen, 2001) and Nitrosococcus ( $\gamma$-proteobacteria) - or autotrophic Archaea (AOA), phylum Thaumarchaeota. The ammonia monooxygenase is a protein of membrane that converts $\mathrm{NH}_{3}$ to $\mathrm{NH}_{2} \mathrm{OH}$ (hydroxylamine, $\mathrm{HAO}$ ), then released into the periplasm to be oxidized by $\mathrm{HAO}$ to $\mathrm{NO}_{2}^{-}$in $\mathrm{AOB}$ (De Boer and Kowalchuk, 2001). No hao gene has been detected in AOA genomes, but $\mathrm{N}$. maritimus seems to produce $\mathrm{NH}_{2} \mathrm{OH}$, possibly through a different enzyme complex (Vajrala et al., 2013). AOA and AOB appear to be mechanistically similar even though differ, within other things, in the dependence of copper (AOB) rather than iron as the redox active for AOA (Stahl and de la Torre, 2012) and in the organization of the operon AMO. In $A O B$ the $A M O$ operon has a conserved organization as amoCAB (Bothe et al., 2000; Nicol G.W., 2006; Norton et al., 2002), while in Thaumarchaeota the organization as $\operatorname{amoAxCB}$ varies between lineages (Bartossek et al., 2012; Blainey et al., 2011).

The majority of studies with soils show AOA as more abundant than AOB and more frequently associated with nitrification rates (Leininger et al., 2006; Mao et al., 2011; Prosser and Nicol, 2012). In addition, AOA seem to prefer ammonia generated from the mineralization of organic $\mathrm{N}$ and are the predominant ammonia oxidizers in acidic soils (Levičnik-Höfferle et al., 2012; Prosser and Nicol, 2012; Zhang et al., 2012) or in environments with little availability of $\mathrm{NH}_{4}{ }^{+}$(Gubry-Rangin et al., 2011; Gubry-Rangin et al., 2010; Nicol et al., 2008). This apparent niche differentiation (Prosser and Nicol, 2012) might be important to consider in view of the economic and ecological costs of fertilization and nitrogen losses.

\section{Heterotrophic nitrification}

The structure and functioning of ammonia oxidation in heterotrophic nitrifiers is not as well described. Most of the heterotrophic nitrifying bacteria have similar enzymes as the autotrophic counterparts as reviewed in (De Boer and Kowalchuk, 2001); and the amoA gene is at least partially homologue to that of N. europaea (Bothe et al., 2000). Nevertheless, the broad range of phylogenetic heterotroph bacteria able to nitrify complicates the use of a molecular assay to determine their presence in the environment. Furthermore, their potential metabolic activities do not ensure the contribution to the $\mathrm{N}$ metabolism (Kowalchuk and Stephen, 2001), since heterotrophic nitrifiers can use organic 
or inorganic N, but ammonia oxidation is not linked to cellular growth as in autotrophs. The presence of heterotrophic nitrifiers in soil can be presumed by the accumulation of nitrate in soils incubated with acetylene, a specific inhibitor of autotrophic nitrification, as suggested for Cerrado soils (Poth et al., 1995). On the other hand, nitrification in Fungi seems to involve the reaction of $\mathrm{N}$ compounds with hydroxyl radicals formed potentially during cell lysis or lignin degradation (De Boer and Kowalchuk, 2001).

Moreover, some of the bacteria able to perform nitrification heterotrophically can combine nitrification-denitrification processes; where denitrification is used by the organism to dissipate reducing equivalents (NADH) under low oxygen conditions, allowing a greater growth rate on an environment with substrate in excess (De Boer and Kowalchuk, 2001), which is less likely in Cerrado soils.

\section{Denitrification}

Denitrification alone is represented as the reduction of $\mathrm{NO}_{3}^{-}$to $\mathrm{NO}_{2}^{-}$, and subsequently to $\mathrm{NO}, \mathrm{N}_{2} \mathrm{O}$ and $\mathrm{N}_{2}$ by the same organism or more commonly by different organisms, thus considered a modular process (Graf et al., 2014). The reduction of $\mathrm{NO}_{2}{ }^{-}$to NO is catalyzed either by a copper-containing enzyme, that can be identified by the measurement of the gene nirK abundance; or the nitrite reductase encoded by nirS which is a cytochrome cd1 (Mohan et al., 2004). These are dissimilatory enzymes associated with electron transport phosphorylation. However, nitrite reductases can also be assimilatory when the reduction of $\mathrm{NO}_{2}^{-}$leads to $\mathrm{NH}_{4}{ }^{+}$. These use reduced pyrimidine nucleotides or ferredoxin as electron donor: the cytoplasmatic NirB is more common in fermentative bacteria and the periplasmic nitrite reductase, deduced by the presence of the gene nrfA in the environment, is found in a wider range of bacteria than the above (Mohan et al., 2004).

Denitrification is dominant on nitrate-rich environment with low electron donors' concentration; however, $\mathrm{NO}_{3}{ }^{-}$and $\mathrm{NO}_{2}^{-}$reduction to $\mathrm{NH}_{4}{ }^{+}$predominates on an electron-rich environment where $\mathrm{NO}_{3}^{-}$is in low concentration. Dissimilatory nitrite reduction to ammonium (DNRA), known also as fermentative reduction of nitrate or ammonification, is the concurrent process to denitrification, representative in reduced and C-rich environments. Available soil literature is smaller for DNRA than denitrification, even though DNRA is also a process widespread among bacteria (Mohan et al., 2004). DNRA was suggested as a short-circuit of $\mathrm{N}$ cycle, returning $\mathrm{NO}_{3}^{-}$to $\mathrm{NH}_{4}{ }^{+}$(Cole and Brown, 1980), and despite not frequently considered in terrestrial experiments, since it is an anaerobic 
process, it can be relevant in soils (Rütting et al., 2011). On the other hand, anammox, the anaerobic ammonia oxidation to $\mathrm{N}_{2}$ seems to be strictly present in anoxic environments.

\section{Denitrifiers guilds and $\mathrm{N}$ trace gases emission}

A microbial guild is described as a group of organisms occurring in the same space and time, and that use same resources (Fauth et al., 1996). The relative abundance of different microbial guilds is dependent on soil characteristics. An increase in soil water content after the first rains that follow the dry season in the Cerrado promoted higher mineralization (Nardoto and Bustamante, 2003), reflecting a higher microbial activity and nitrification (da Silva, 2004). More specifically, AOA and AOB differ in their niches in soil according with different $\mathrm{pH}$ and ammonia availability. Similarly, denitrifier's guilds, meaning organisms containing either nirk or nirS genes, also respond differently to the environment (Enwall et al., 2010; Jones and Hallin, 2010) as well as the nosZ organisms from clade I or II (Jones et al., 2013). The ratios of nirS/nirK type and nosZ clade I/clade II are related and have an effect on the soil $\mathrm{N}_{2} \mathrm{O}$ sink capacity, more significant in environments dominated by nos $Z$ clade II (Jones et al., 2014).

In turn, the balance between the processes described above controls $\mathrm{N}$ trace gases emissions (Conrad, 1996). Emission of $\mathrm{NO}$ and $\mathrm{N}_{2} \mathrm{O}$ can occur either during nitrification or denitrification. A special attention is given to agricultural fields as fertilization increases the microbial transformation of reactive $\mathrm{N}$ (Galloway and Cowling, 2002). $\mathrm{N}_{2} \mathrm{O}$ is a significant greenhouse gas after $\mathrm{CO}_{2}$ and $\mathrm{CH}_{4}$, and is also a relevant ozone depleting gas (Ravishankara et al., 2009) when oxidized to NO, as reviewed recently (Kanter et al., 2013). In addition, N oxides ( $\mathrm{NO}$ and $\mathrm{NO}_{2}$ ) are removed from the troposphere as nitric acid, contributing to ecosystems acidification.

Emissions of nitric oxide (NO) represents $0.4 \mathrm{~kg} \mathrm{~N}^{-1} \mathrm{year}^{-1}$ loss of $\mathrm{N}$ in the Cerrado (Bustamante et al., 2006) and is emitted in higher concentration than $\mathrm{N}_{2} \mathrm{O}$ in those soils, as expected by the dry and well-aerated characteristic of these soils (Pinto et al., 2002). The "hole-in-the-pipe" concept states that soil water content is the principal control on the balance of production, consumption and diffusive transport between $\mathrm{NO}, \mathrm{N}_{2} \mathrm{O}$ and $\mathrm{N}_{2}$ in soils (Davidson et al., 2000). The ratio of emission between $\mathrm{N}_{2} \mathrm{O}$ and $\mathrm{NO}$ should be 1 in soils with water filled pore space (WFPS) at 60\% (Davidson et al., 2000). Pinto et al. (2002) also emphasized that soil moisture and vegetation were more strongly associated with NO emission than fire regime. In addition, $\mathrm{N}$ availability influences both gases emission, 
however, in a wet soil $\mathrm{N}_{2} \mathrm{O}$ is more prevalent and the analysis of only $\mathrm{NO}$ would lead to false conclusions that nitrogen availability does not matter (Davidson et al., 2000).

Cerrado soils can experience short moments of flooding during the first rainfall after the dry season, but they are often described as well-drained, leached and oligotrophic soils (Ribeiro and Walter, 2008). The first rains after the dry season promote an increase of 100 fold on the emission of NO in the Cerrado, which does not continue during the wet season (Pinto et al., 2002). Although denitrification can occur in aerated soils (Braker et al., 2015), it is not expected in the Cerrado soils, especially because of the low accumulation of $\mathrm{NO}_{3}{ }^{-}$in these soils, and the dominance of $\mathrm{N}$ form as $\mathrm{NH}_{4}{ }^{+}$is associated with low $\mathrm{N}$ trace gases emission (Davidson et al., 2000).

\section{$N$ fixation and other sources of $N$}

Reactive $\mathrm{N}$ enters the system through biological or chemical $\mathrm{N}$ fixation, which is the conversion of the inert gas $\mathrm{N}_{2}$ to $\mathrm{NH}_{4}{ }^{+}$. In the Cerrado soils, the biological nitrogen fixation (16 a $44 \mathrm{~kg} \mathrm{~N} \mathrm{ha}^{-1}$ year $^{-1}$ ) exceeds the abiotic fixation through electrical discharges ( $4 \mathrm{~kg} \mathrm{~N} \mathrm{ha-}$ ${ }^{1}$ year-1) (Bustamante et al., 2006; Cleveland et al., 1999). This important source of $N$ is possibly related with the high abundance of plant species from the Fabaceae family in the Cerrado (Filgueiras, 2002), even though very few studies have focused on the nodular activity of these plants (Bustamante et al., 2012C). It is recognized though that $\mathrm{O}_{2}, \mathrm{P}, \mathrm{Ca}$ and Al concentrations, soil moisture, bacterial density and plant needs of $\mathrm{N}$ determine the ability of nodulation by symbiotic dyazotrophs (Bustamante et al., 2006). As well as for denitrifiers, the genes encoding the enzyme nitrogenase (nifH being the gene used to quantify $\mathrm{N}$ fixation) are widespread in the Bacteria and Archaea domains. Although nitrogenase is an enzymatic complex sensible to oxygen, dyazotrophs are not necessarily anaerobic (Falkowski et al., 2008).

Organic matter mineralization recycles $\mathrm{N}$ in soils, which can then be assimilated by plants and microorganisms, or lost via $\mathrm{NH}_{3}$ volatilization, enzymatic denitrification and $\mathrm{NO}_{3}{ }^{-}$ leaching as discussed above. These losses depend on climatic and edaphic conditions, but, in general, increase with land use change. Volatilization of ammonia increases with soil alcalinization, leaching with increased nitrification and consequently higher substrate for denitrification and emissions of $\mathrm{N}$ trace gases. Despite the fact that the Haber-Bosch method allowed the increase for food production, there were consequences to the ecosystem functioning, as $\mathrm{N}_{2} \mathrm{O}$ is a greenhouse gas, $\mathrm{NO}$ catalyzes the ozone layer 
destruction, and nitrate causes eutrophication in water courses due to increased leaching. Furthermore, only half of $\mathrm{N}$ added in crops is used by the plants (Galloway and Cowling, 2002).

$\mathrm{NO}_{3}{ }^{-}$is considered the main form of nutrition used by plants in well aerated soils, where nitrification is more prone to happen. However, in Cerrado soils, the greatest part of inorganic $\mathrm{N}$ is found in the form of ammonia (Nardoto and Bustamante, 2003), suggested to be related with the low $\mathrm{pH}$ found in these soils, or competition between plants and microorganisms. Furthermore, the availability of inorganic $\mathrm{N}$ in soil depends on organic matter mineralization, which is lower than $\mathrm{N}$ immobilization in Cerrado soils (Nardoto and Bustamante, 2003). For example, some forests in their climax are more efficient in $\mathrm{N}$ use, potentially by inhibiting nitrification, and so maintaining predominantly ammonia than nitrate in the soil solution, which leads to lower losses of $\mathrm{N}$ as reviewed recently (Subbarao et al., 2015). Therefore, the observation of dynamics between plants and microbial community in the belowground can help understand the balance in $\mathrm{N}$ transformations and $\mathrm{N}$ retention and therefore provide a model for a more sustainable crop productivity.

\section{Land use impact on microbial communities}

Brazil is the fourth worldwide country in agriculture production, which depends on inorganic fertilizers. The progressing frontier of agriculture and managed pasture for cattle breeding promoted the change of approximately 53\% change of the Cerrado's original area (Beuchle et al., 2015). Soybean, maize, cotton and sugarcane stand out as the major crops cultivated in the Cerrado region, in which only the first is partially independent on the addition of fertilizers (Mendes et al., 2003). A study published in 2010 showed that $81 \%$ of exported soybean was produced in Brazil, EUA and Argentina together. This reflects a

global trade of biogeochemical $\mathrm{N}$ cycling represented in $25 \%$ by the soybean commodity (Lassaletta et al., 2014).

Land use impacts soil microbiota and consequently the terrestrial ecological services it provides (e.g. decomposition and nutrient cycling), it modifies $\mathrm{C}$ and $\mathrm{N}$ dynamics (Bustamante et al., 2012C), and it changes $\mathrm{C}$ and $\mathrm{N}$ stocks and sink and greenhouse gases emission (Carvalho et al., 2009). In turn, the alteration in $\mathrm{N}$ dynamics leads to a reduction of biodiversity (Bustamante et al., 2012C; Jacobson et al., 2011), facilitates the invasion by exotic species (Lannes et al., 2012) and modifies decomposition and nutrient cycling (Kozovits et al., 2007). 
Then again, governmental initiatives are also concerned with preserving the Brazilian biomes biodiversity in conservation unities. However, only $2.2 \%$ of this biome is under unities of integral protection and other 1.9\% in unities of sustainable use (Klink and Machado, 2005; Marris, 2005) ensuring its status of a hotspot for biodiversity conservation (Myers et al., 2000). In this context, it is important to have in mind that soil is the main actor in the ecosystem conservation, especially in seasonally dry environments as the Cerrado, where climatic change will probably modify rain distribution and regime, changing also the fire frequency and potentially nutrients and biomass loss (Bustamante et al., 2012c).

More specifically, soil microbial diversity contributes to the resistance/resilience of the system, which means that the lower diversity after land use change can alter the stability of the ecosystem. Mao et al. (2011) observed that $\mathrm{N}$ fertilization for bioenergy crops (Zea mays and Miscanthus giganteus) altered the microbial communities, and induced the modification on $15 \%$ to $30 \%$ of the relative abundance of nitrification and denitrification genes. This is an example of how agriculture impacts microbial potential ecological functions. Same results were observed in the Cerrado soils, where soybean cultivation reduced microbial $\mathrm{N}$ independent on the soil management or the plant growing stage in comparison to a soil under native Cerrado (Perez et al., 2005). Moreover, land use management in the Amazonian forest changed the composition and abundance of soil microbial communities, related with the modification in soil pH and OM (Paula et al., 2014).

Despite the known functionality of soil microbiota regulating fertility and health by decomposing organic matter and through biogeochemistry we still have a lot to understand from microbial patterns of distribution in terrestrial ecosystems. Free-living microorganisms also present patterns of biogeography (Martiny et al., 2006), and should be included in models for biome sustainability specially in biomes threatened as the Cerrado. As discussed, these correlations of change in soil characteristics and microbial communities can be monitored targeting specific genes with molecular techniques that complement ecological and edaphic research in the quest to value ecosystems services provided by soil biota. This work main objective is to link soil characteristics with $\mathrm{N}$ cycling dynamics and the microbial functional potential in the Cerrado biome, as a step to identify key drivers of sink/source of $\mathrm{N}$ in those soils, and allow further incorporation of biological drivers into predictive models. 


\title{
Chapter 2 - Distribution of microbial communities in two Cerrado conservation parks with a metagenomics approach, with special focus on the $\mathrm{N}$ metabolism ${ }^{2}$
}

"everything is everywhere" and why do we care

Baas Becking

\begin{abstract}
Nitrogen is the base for primary productivity, and primarily cycled by the soil microbiota. Climate change, land use side effects and nitrogenous fertilizers employment are changing the global $\mathrm{N}$ budget. The Cerrado is the largest savanna in South America, and as others savannas in the world, is suffering from the land use change to agriculture and pasture. Yet, little is known of how these changes affect soil microbial communities. Undisturbed areas are essential to understand the natural processes rates that occur in soil. We used shotgun metagenomics to compare the functional attributes of $\mathrm{N}$ cycling from the soil microbiota present in two parks for conservation of the Cerrado biome, $500-\mathrm{km}$ distant from each other, with varying altitude, soil texture and water content. Types of vegetation sampled within each park masked the altitude and distance effects. The soils with greater and lower soil water content presented the highest levels of a-diversity, which may relate with greater evenness of species to overcome a less enabling environment. $\mathrm{N}$ fixation, nitrosative stress and ammonification from nitrate and nitrite differed significantly between the sites sampled. Across all soils, the assimilation of ammonia and ammonification were the most abundant subsystem of nitrogen cycle, corroborating the Cerrado literature that states ammonia as the main nitrogen form. We detected genes for denitrification enzymes, but only two hits for the nitrification process were described. This study suggests that the $\mathrm{N}$ cycle processes occurs differently between the sites. Furthermore, we suggest that each type of vegetation is relevant for $\mathrm{N}$ conservation in this biome.
\end{abstract}

Keywords: Brazilian savanna, Cerrado, $\mathrm{N}$ cycle, ammonia, nitrification, denitrification

\footnotetext{
${ }^{2} \mathrm{~A}$ modified version of this manuscript will be submitted to publication, possibly including a discussion on the cycle of $\mathrm{C}$ and $\mathrm{S}$.
} 


\section{Introduction}

Savanna ecosystems hold almost one fifth of the world's population. Cerrado is the main tropical savanna in the south hemisphere. It is a representative biome in central Brazil, the second largest in South America, and a wildlife corridor for species from the Amazon and Atlantic rainforests. As others savannas, Cerrado is controlled by the interaction between water and nutrient availability (Bustamante et al., 2006). Cerrado has an alternating wet and dry seasons and fire frequency that might change attributable to the global climatic changes, as higher temperatures, decreased rainfall and longer dry season may have an impact on net ecosystem exchanges and reduced nutrient stocks (Bustamante et al., 2012c).

The Cerrado is characterized by a continuous herbaceous layer over which stands a discontinuous tree/shrub stratum, resulting on a range of ecosystems from grassland to savanna and forest formations. This variation on the types of vegetation found in the Cerrado biome is related to the type of soil, mostly weathered with low nutrient availability (Reatto et al., 1998), which may present varying contents of nitrogen according to the tree-shrub layer density, the fire regime and the land use change (Bustamante et al., 2006). Plant type and soil texture influence microbial community structure in the rhizosphere soil (Tkacz et al., 2015).

Due to its progressively land use change - approximately $53 \%$ of the Cerrado landscape has been transformed (Beuchle et al., 2015) - the Cerrado is considered a hotspot for biodiversity conservation (Myers et al., 2000), and approximately 2\% of this biome is under protection (Marris, 2005). However, conservation unities designated for environment protection are not necessarily continuous (Beuchle et al., 2015). In addition, a special attention for conservation is paid to forest formations bordering water courses in the Brazilian legislation. Nevertheless, ecological insurance theory assumes that a better occupation of space by higher diversity leads to a better system productivity (Yachi and Loreau, 1999), i.e. the distribution of Cerrado in different vegetation patches. Similarly, we suggest that microbial community performs differently in these patches, due to the different resources and soil characteristics.

The relative abundance of microbial phylogenetic groups varies according to Cerrado types of vegetation, i.e. savannas grassland and shrubland or riverbank (Araujo et al., 2012; Catão et al., 2013; de Castro et al., 2008; Quirino et al., 2009). Soil pH is directly 
linked to nutrient availability in soil and is often associated with the distribution of bacterial communities in soil (Bru et al., 2011; Griffiths et al., 2011; Kuramae et al., 2012; Rousk et al., 2010) (Lauber et al., 2009). However, in the Cerrado soil moisture is more strongly related with microbial community structure (Catão et al., 2014; Pereira de Castro et al., 2016; Viana et al., 2011), which can be associated with soil texture and its water retention capacity. Recently, Pereira de Castro et al. (2016) discussed the general metabolic potential distribution in the Cerrado biome besides the taxonomy approach. Nonetheless, until now no work has focused on the microbial genes associated with nitrogen cycling in the Cerrado, despite the need to understand microbial governed $\mathrm{N}$ pathways in undisturbed ecosystem and the use of high- throughput shotgun sequencing to characterize the $\mathrm{N}$ metabolism in other environmental samples (Andreote et al., 2012; Cobo-Díaz et al., 2015; Pfister et al., 2010).

Nitrogen is mainly recycled in soils through nitrogen fixation, SOM mineralization, ammonification, nitrification and denitrification. In undisturbed ecosystems, $\mathrm{N}$ leakage is minimized, and nitrification is restricted, but little is understood about this in the Cerrado biome. The ecology of $\mathrm{N}$ dynamics between compartments has been reviewed beforehand for this biome (Bustamante et al., 2006), which is characterized by a high $\mathrm{NH}_{4}: \mathrm{NO}_{3}$ ratio, low nitrification and low $\mathrm{N}$ gas emission.

This work was conducted to investigate the variation of relative abundance of taxonomic and functional potential genes in the soil of Cerrado. It was considered the range of types of vegetation found in two $500-\mathrm{km}$ distant parks of conservation with different altitudes, and pluviometry. The first hypothesis assumes that vegetation and edaphic characteristics, which vary within and between parks, will reflect on the microbial diversity, due to different resource use or environment constraints. Secondly, we hypothesized that genes related to $\mathrm{N}$ metabolism would vary with the soil characteristics specific to each vegetation type as carbon and $\mathrm{NH}_{4}{ }^{+}$availability, $\mathrm{pH}$ and soil moisture. To test these, 24 metagenomes (eight areas in triplicates) were sequenced to describe the functional and taxonomic categories of Cerrado soils microbiota at a regional scale. We believe that microbial controls of $\mathrm{N}$ conservation - the balance of assimilative and dissimilative processes - in the Cerrado soils can help future works of biogeochemical models or soil management improvement. 


\section{Material and methods}

Soil sampling and physicochemical analyses

This study was performed in two sites: the National Park of the Chapada dos Veadeiros (PNCV) and State Park of Serra Azul (PESA) both located in Central Brazil (Figure 9), classified as the Cerrado biome and approximately $500 \mathrm{~km}$ distant (coordinates provided in Table S1). The two sites diverge in altitude (Table S1). The climate of these regions is classified as Koppen Aw and the annual mean rainfall is of $1500 \mathrm{~mm}$ mostly during the rainy season, which happens from October to May. Sampling was performed at the end of the rainy season: the accumulated rain and the mean temperature from the month of April (2013) until the sampling day in the PNCV was of $2.2 \mathrm{~mm}$ and $21^{\circ} \mathrm{C}$; for the PESA no rain was measured on the month of May (2013) and an average $27^{\circ} \mathrm{C}$ were measured. In total 8 areas and 6 different vegetation types were sampled.

In the PNCV and the PESA, beside some other parks, it was installed modules of standardized sampling thanks to the project financed by CNPq "Diversidade biológica do Cerrado: estruturas e padrões".. These modules were created within the "Rede ComCerrado" (Portaria MCT 319, 7 May 2009), which is a network founded by several research groups from public institutions in Brazil to monitor Cerrado's biodiversity. These modules establish $5 \mathrm{~km}^{2}$ area bordered by 2 lines oriented east-west $1 \mathrm{~km}$ apart and $5 \mathrm{~km}$ long as standardized in the literature to sample extensive biomes as the Amazon rainforest (Magnusson et al., 2005). Along these $5 \mathrm{~km}, 10$ parcels ( 5 in each line) were established, one per $\mathrm{km}$ and a perpendicular line of $250 \mathrm{~m}$ was draw along the terrain level curve (Figure $9 \mathrm{C}$ ).

Soil was sampled from a total of 24 points ( 8 sites in triplicates from the upper 10 $\mathrm{cm}$. Replicates in each site were taken approximately $50 \mathrm{~m}$ apart (at 50, 100 and $150 \mathrm{~m}$ inside the parcel line (red line in Figure $9 \mathrm{C}$ ), soil was sieved through a 2-mm mesh and stored on ice upon collection and on $-20^{\circ} \mathrm{C}$ in the laboratory before physicochemical and molecular analysis. Soil texture and content of macro and micronutrients were measured by using standard methods (Soils Embrapa-SNLCS) at SoloQuímica, Inc, Brasília, Brazil. Inorganic N was determined as described previously (Catão et al., 2016).

The PNCV was created in 1981 and includes the municipal areas of Alto Paraíso de Goiás, Cavalcante and Colinas do Sul (state of Goiás) (MMA, 2011). Soils are poor in nutrients and, with varying types of soil, as Neossolos litólicos (Entisol, Udorthent), Plintossolos (Oxisol), Cambissolos (Inceptisol), hydromorphic soils and Latossolos (Oxisol) (Haridasan, 
2007). In the PNCV, soil samples were obtained in a Cerrado sensu stricto (SS), in a riverbank gallery forest, hereafter called "Mata de galeria" (MG), a flooded grassland, hereafter named "Campo limpo" (CL) and a Cerrado "rupestre" (CR), (Figure 2). The physicochemical variables observed in the sampled soils are described in Table 1.

Table 1. Physicochemical variables (mean \pm SE) of the sampled sites in PNCV

\begin{tabular}{|c|c|c|c|c|}
\hline \multirow{2}{*}{$\begin{array}{l}\text { Park } \\
\text { Type }\end{array}$} & \multicolumn{4}{|c|}{ National Park of the Chapada dos Veadeiros } \\
\hline & MG & $\mathrm{CL}$ & SS & $C R$ \\
\hline $\mathrm{SWC}\left(\% \mathrm{H}_{2} \mathrm{O} \mathrm{g}^{-1} \mathrm{DS}\right)$ & $45.8^{*}$ & $48.1 \pm 8.8$ & $17.8 \pm 1.8$ & $6.0 \pm 0.6$ \\
\hline Clay $\left(\mathrm{g} \mathrm{kg}^{-1}\right)$ & $233 \pm 8$ & $167 \pm 22$ & $333 \pm 22$ & $133 \pm 8$ \\
\hline Sand $\left(\mathrm{g} \mathrm{kg}^{-1}\right)$ & $617 \pm 22$ & $758 \pm 22$ & $608 \pm 17$ & $842 \pm 8$ \\
\hline Silt $\left(\mathrm{g} \mathrm{kg}^{-1}\right)$ & $150 \pm 29$ & $75 \pm 14$ & $58 \pm 8$ & $25 \pm 0$ \\
\hline $\mathrm{pH}$ in $\mathrm{H}_{2} \mathrm{O}$ & $5.70 \pm 0.06$ & $5.27 \pm 0.34$ & $4.93 \pm 0.09$ & $5.00 \pm 0.06$ \\
\hline $\mathrm{pH}$ in $\mathrm{KCl}$ & $3.97 \pm 0.12$ & $4.20 \pm 0.06$ & $3.73 \pm 0.03$ & $3.70 \pm 0.06$ \\
\hline$P\left(\mathrm{mg} \mathrm{dm}^{-3}\right)$ & $10.83 \pm 2.88$ & $4.73 \pm 0.66$ & $1.17 \pm 0.19$ & $2.53 \pm 0.20$ \\
\hline $\mathrm{Ca}\left(\mathrm{cmol}_{\mathrm{c}} \mathrm{dm}^{-3}\right)$ & $1.10 \pm 0.45$ & $0.57 \pm 0.12$ & $0.50 \pm 0.06$ & $0.57 \pm 0.15$ \\
\hline $\mathrm{Mg}\left(\mathrm{cmol}_{\mathrm{c}} \mathrm{dm}^{-3}\right)$ & $0.53 \pm 0.09$ & $0.30 \pm 0.00$ & $0.33 \pm 0.03$ & $0.30 \pm 0.00$ \\
\hline $\mathrm{K}\left(\mathrm{cmol}_{\mathrm{c}} \mathrm{dm}^{-3}\right)$ & $0.17 \pm 0.02$ & $0.02 \pm 0.01$ & $0.09 \pm 0.01$ & $0.04 \pm 0.00$ \\
\hline $\mathrm{Na}\left(\mathrm{cmol}_{\mathrm{c}} \mathrm{dm}^{-3}\right)$ & $0.02 \pm 0.01$ & $0.02 \pm 0.00$ & $0.02 \pm 0.00$ & $0.01 \pm 0.00$ \\
\hline $\operatorname{CTC}\left(\mathrm{cmol}_{\mathrm{C}} \mathrm{dm}^{-3}\right)$ & $9.33 \pm 0.33$ & $6.00 \pm 0.58$ & $7.67 \pm 0.33$ & $5.67 \pm 0.33$ \\
\hline $\mathrm{Al}\left(\mathrm{cmol}_{\mathrm{c}} \mathrm{dm}^{-3}\right)$ & $2.33 \pm 0.52$ & $0.90 \pm 0.15$ & $1.80 \pm 0.15$ & $1.00 \pm 0.10$ \\
\hline $\mathrm{H}+\mathrm{Al}\left(\mathrm{cmol}_{\mathrm{c}} \mathrm{dm}^{-3}\right)$ & $7.27 \pm 0.64$ & $5.13 \pm 0.35$ & $6.53 \pm 0.17$ & $4.43 \pm 0.38$ \\
\hline$C\left(\mathrm{~g} \mathrm{~kg}^{-1}\right)$ & $182.07 \pm 51.98$ & $47.17 \pm 13.20$ & $29.33 \pm 2.60$ & $11.97 \pm 1.24$ \\
\hline $\mathrm{OM}\left(\mathrm{g} \mathrm{kg}^{-1}\right)$ & $313.17 \pm 89.42$ & $81.13 \pm 22.68$ & $50.43 \pm 4.47$ & $20.60 \pm 2.15$ \\
\hline$B\left(m g d^{-3}\right)$ & $0.63 \pm 0.06$ & $0.70 \pm 0.01$ & $0.69 \pm 0.07$ & $0.58 \pm 0.10$ \\
\hline $\mathrm{Cu}\left(\mathrm{mg} \mathrm{dm} \mathrm{m}^{-3}\right)$ & $0.13 \pm 0.04$ & $0.19 \pm 0.04$ & $0.17 \pm 0.02$ & $0.15 \pm 0.03$ \\
\hline $\mathrm{Fe}\left(\mathrm{mg} \mathrm{dm} \mathrm{m}^{-3}\right)$ & $72.47 \pm 16.51$ & $158.33 \pm 9.02$ & $246.00 \pm 54.99$ & $136.27 \pm 27.79$ \\
\hline $\mathrm{Mn}\left(\mathrm{mg} \mathrm{dm}^{-3}\right)$ & $5.68 \pm 0.88$ & $3.31 \pm 0.10$ & $3.41 \pm 0.12$ & $2.94 \pm 0.03$ \\
\hline $\mathrm{Zn}\left(\mathrm{mg} \mathrm{dm} \mathrm{m}^{-3}\right)$ & $0.85 \pm 0.18$ & $0.52 \pm 0.17$ & $0.40 \pm 0.03$ & $0.19 \pm 0.02$ \\
\hline $\mathrm{S}\left(\mathrm{mg} \mathrm{dm}^{-3}\right)$ & $25.03 \pm 8.79$ & $43.30 \pm 7.40$ & $12.70 \pm 2.04$ & $10.43 \pm 1.21$ \\
\hline
\end{tabular}

SWC: Soil water content. " Measurement from only one sample. MG: Mata de galeria; CL: Campo limpo; SS: Cerrado sensu stricto, CR: Cerrado rupestre

The PESA is located entirely in the municipal area of Barra do Garças (state of Mato Grosso) and occupies 11,002.4 ha, in which the topography can vary (350-730 m). Soils are predominantly Litólicos (Udorthent) and Latossolo amarelo (Oxisol, Udox) (in the plain areas). PESA was created in 31 May 1994, accordingly with the State Law of Matogrosso 6.439. More about the vegetation types in this park can be found in the literature (SANCHEZ, 2011). Soil samples were obtained in a Cerrado sensu stricto (SS), in a riverbank 
gallery forest, hereafter called "Mata de galeria" (MG), a semi-deciduous forest (FSD) and a shrubland (CD) (Figure 2).

Table 2. Physicochemical variables (mean $\pm \mathrm{SE}$ ) of the sampled sites in the PESA

\begin{tabular}{|c|c|c|c|c|}
\hline \multirow{2}{*}{$\begin{array}{l}\text { Park } \\
\text { Type }\end{array}$} & \multicolumn{4}{|c|}{ State Park of Serra Azul } \\
\hline & MG & CS & FSD & SS \\
\hline $\mathrm{SWC}\left(\% \mathrm{H}_{2} \mathrm{O} \mathrm{g}^{-1} \mathrm{DS}\right)$ & $16.7 \pm 2.4$ & $14.8 \pm 1.6$ & $17.7 \pm 4.3$ & $10.0 \pm 1.2$ \\
\hline Clay $\left(\mathrm{g} \mathrm{kg}^{-1}\right)$ & $283 \pm 8$ & $408 \pm 8$ & $283 \pm 22$ & $283 \pm 8$ \\
\hline Sand $\left(\mathrm{g} \mathrm{kg}^{-1}\right)$ & $600 \pm 29$ & $383 \pm 22$ & $542 \pm 30$ & $658 \pm 8$ \\
\hline Silt $\left(\mathrm{g} \mathrm{kg}^{-1}\right)$ & $117 \pm 22$ & $208 \pm 17$ & $175 \pm 25$ & $58 \pm 8$ \\
\hline $\mathrm{pH}$ in $\mathrm{H}_{2} \mathrm{O}$ & $4.83 \pm 0.09$ & $4.73 \pm 0.09$ & $5.00 \pm 0.17$ & $5.07 \pm 0.03$ \\
\hline $\mathrm{pH}$ in $\mathrm{KCl}$ & $3.50 \pm 0.06$ & $3.67 \pm 0.03$ & $3.90 \pm 0.26$ & $3.67 \pm 0.03$ \\
\hline$P\left(m g d^{-3}\right)$ & $4.57 \pm 0.35$ & $0.77 \pm 0.09$ & $8.90 \pm 6.06$ & $3.17 \pm 0.79$ \\
\hline $\mathrm{Ca}\left(\mathrm{cmol}_{\mathrm{c}} \mathrm{dm}^{-3}\right)$ & $0.77 \pm 0.12$ & $0.57 \pm 0.09$ & $0.70 \pm 0.06$ & $0.63 \pm 0.09$ \\
\hline $\mathrm{Mg}\left(\mathrm{cmol}_{\mathrm{c}} \mathrm{dm}^{-3}\right)$ & $0.53 \pm 0.15$ & $0.33 \pm 0.09$ & $0.47 \pm 0.12$ & $0.40 \pm 0.00$ \\
\hline $\mathrm{K}\left(\mathrm{cmol}_{\mathrm{c}} \mathrm{dm}^{-3}\right)$ & $0.10 \pm 0.01$ & $0.10 \pm 0.01$ & $0.35 \pm 0.04$ & $0.13 \pm 0.01$ \\
\hline $\mathrm{Na}\left(\mathrm{cmol}_{\mathrm{c}} \mathrm{dm}^{-3}\right)$ & $0.01 \pm 0.00$ & $0.01 \pm 0.00$ & $0.04 \pm 0.02$ & $0.01 \pm 0.00$ \\
\hline $\mathrm{CTC}\left(\mathrm{cmol}_{\mathrm{c}} \mathrm{dm}^{-3}\right)$ & $6.67 \pm 0.33$ & $5.33 \pm 0.33$ & $7.00 \pm 1.15$ & $6.33 \pm 0.33$ \\
\hline $\mathrm{Al}\left(\mathrm{cmol}_{\mathrm{c}} \mathrm{dm}^{-3}\right)$ & $1.87 \pm 0.23$ & $1.50 \pm 0.10$ & $1.40 \pm 0.81$ & $1.40 \pm 0.20$ \\
\hline $\mathrm{H}+\mathrm{Al}\left(\mathrm{cmol}_{\mathrm{c}} \mathrm{dm}^{-3}\right)$ & $5.27 \pm 0.13$ & $4.50 \pm 0.10$ & $5.60 \pm 1.14$ & $5.27 \pm 0.13$ \\
\hline$C\left(g_{k g}^{-1}\right)$ & $23.97 \pm 2.40$ & $21.83 \pm 0.60$ & $43.00 \pm 9.00$ & $24.40 \pm 1.18$ \\
\hline $\mathrm{OM}\left(\mathrm{g} \mathrm{kg}^{-1}\right)$ & $41.20 \pm 4.13$ & $37.20 \pm 0.99$ & $73.97 \pm 15.49$ & $41.97 \pm 2.02$ \\
\hline$B\left(m g d^{-3}\right)$ & $0.20 \pm 0.04$ & $0.21 \pm 0.07$ & $0.29 \pm 0.06$ & $0.35 \pm 0.06$ \\
\hline $\mathrm{Cu}\left(\mathrm{mg} \mathrm{dm}^{-3}\right)$ & $0.32 \pm 0.01$ & $0.32 \pm 0.01$ & $0.44 \pm 0.05$ & $0.42 \pm 0.04$ \\
\hline $\mathrm{Fe}\left(\mathrm{mg} \mathrm{dm}^{-3}\right)$ & $337.67 \pm 33.89$ & $157.67 \pm 8.51$ & $135.67 \pm 34.37$ & $288.00 \pm 15.28$ \\
\hline $\mathrm{Mn}\left(\mathrm{mg} \mathrm{dm}^{-3}\right)$ & $44.40 \pm 18.09$ & $4.06 \pm 0.16$ & $53.27 \pm 23.20$ & $17.90 \pm 7.11$ \\
\hline $\mathrm{Zn}\left(\mathrm{mg} \mathrm{dm^{-3 }}\right)$ & $1.80 \pm 0.32$ & $0.98 \pm 0.04$ & $3.22 \pm 0.80$ & $1.55 \pm 0.23$ \\
\hline $\mathrm{S}\left(\mathrm{mg} \mathrm{dm}^{-3}\right)$ & $5.40 \pm 1.39$ & $7.33 \pm 0.54$ & $4.97 \pm 1.35$ & $6.13 \pm 1.71$ \\
\hline
\end{tabular}

, SWC: Soil water content. ${ }^{+}$Measurement from only one sample. MG: Mata de galeria; SS: Cerrado sensu stricto, CS: Campo sujo, FSD: Floresta semi-decídua. 

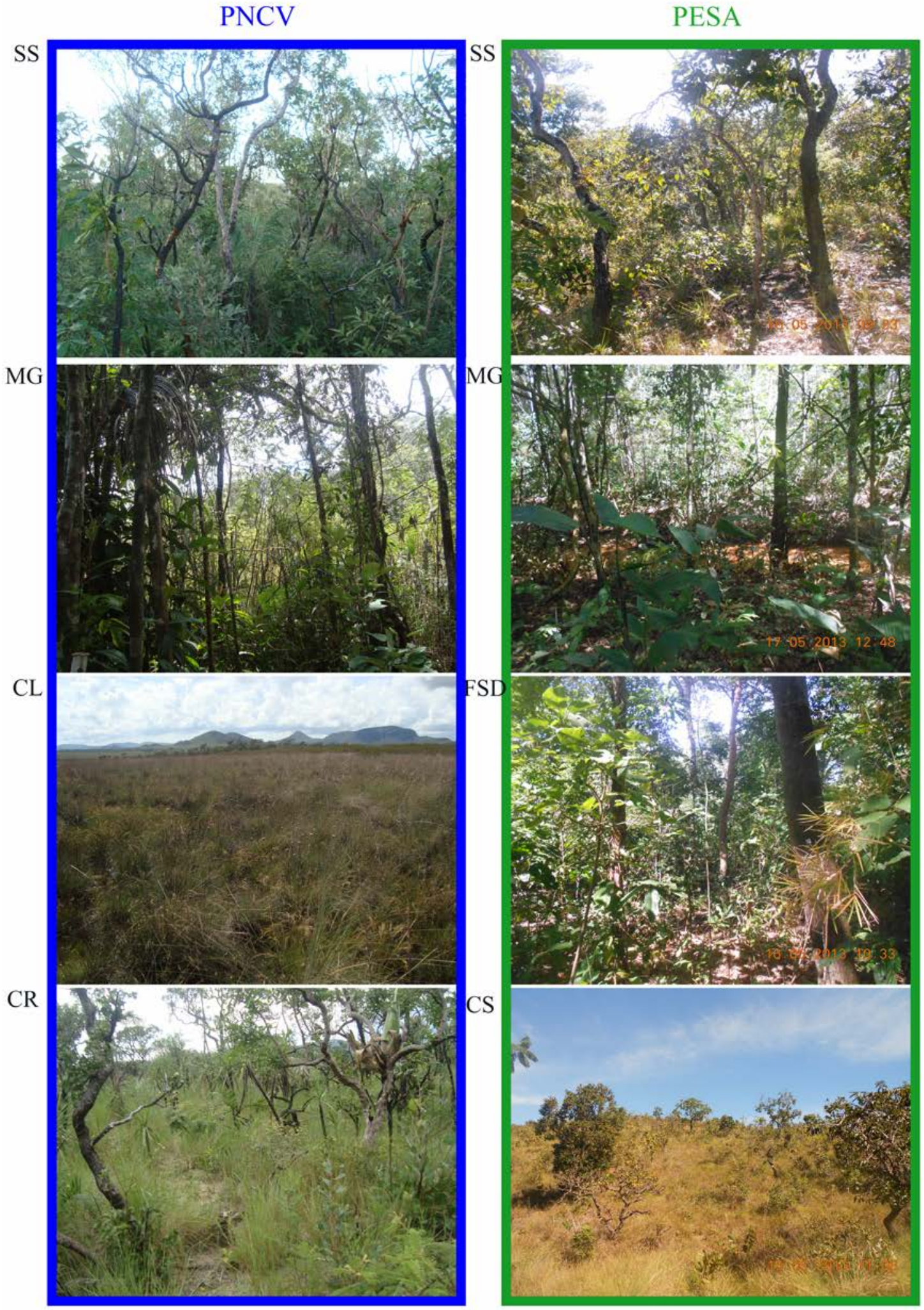

Figure 2. Photographs of the sites sample in the two parks: PNCV - Parque Nacional da Chapada dos Veadeiros; PESA - Parque Estadual da Serra Azul. (SS) Cerrado sensu stricto, (MG) Mata de galeria, (CL) Campo limpo, (CR), Cerrado rupestre, (FSD) Floresta semi-decídua, (CS) Campo sujo. 
DNA extraction and sequencing

DNA was extracted from $0.5 \mathrm{~g}$ of soil with the FastDNA Spin Kit (MP Biomedicals) with additional treatment using solutions steps 2 and 3 from the PowerSoil DNA Isolation Kit (MO Bio Laboratories Inc.) to achieve maximum DNA yields with least of organic contaminants. The extraction was evaluated in $1 \%$ agarose gel electrophoresis. The average concentration of each 24 DNA samples was of $100 \mathrm{ng} / \mu \mathrm{L}$ (Invitrogen Qubit fluorometer dsDNA BR Kit).

Approximately $2 \mu \mathrm{g}$ of DNA was sent to sequence on 454 platform GS FLX + technology (Macrogen, Inc., South Korea) from each sample. Two 454 plates were used to sequence, one for each park; DNA from each site constituted one-quarter of the plate. Raw sequences were uploaded to the MG-RAST server, assigned to the projects SISBIOTA_PESA_2013 (ID 6701; accession numbers 4549601.3-4549612.3) and SISBIOTA_PNCV_april_13 (ID 5456; accession numbers 4530784.3-4530795.3), and processed with default quality control pipeline.

A total of 1,364,104 sequences (average size of 746bp and $515 \mathrm{bp}$, before and after quality control in MG-RAST) for PNCV and 992,685 sequences (average size of 659 bp and $382 \mathrm{bp}$, before and after quality control in MG-RAST) for PESA. After quality control, unassembled sequences were assigned to the taxonomic annotation with BLASTX against the $\mathrm{M}_{5} \mathrm{NR}$ non redundant databases, e-value of $10^{-5}, 80 \%$ of identity cutoff and 50 bp alignment. Functional annotation was performed against the metabolic subsystems SEED database with e-value of $10^{-5}, 60 \%$ of identity cutoff and 15 bp alignment, as default. The MGRAST table format of sequences associated with total organism abundance (best hit classification), total bacteria assignment, total subsystems, and nitrogen metabolism were downloaded and transformed to wide format to $\mathrm{R}$ analysis.

In addition to the analyses of N metabolism annotated genes in PNCV and PESA soils, we compared our results with other metagenomes obtained in the Cerrado biome in a study of comparison between native and managed areas: MG-RAST ID's 4577669.3 to 4577672.3 , 4578924.3 to 4578927.3 and 4578714.3 (Souza et al., 2016).

\section{Statistical analysis}

All analyses were conducted in R version (3.2.2). One-way ANOVA tests were used to make multiple comparisons within each park. Tukey-Kramer post-hoc tests was used when statistical difference was significant $(p<0.005)$. Differences for physicochemical and 
metagenomics data between parks and between SS or MG present in both parks were tested with T-test or the non-parametric Wilcoxon test. Statistical analysis with the relative abundance of either annotated taxonomy or metabolisms did not consider unclassified reads. Relative abundance is meant as the number of annotated genes for a certain classification (either of taxonomy or functional) divided by the total of annotated genes for each sample. Principal component analysis (PCA) were constructed in R with prcomp function set to TRUE for correlation, considering that physicochemical variables have different scales and variance. PCA were made with FactoMineR and factoextra packages. All graphs in the boxplot format were prepared in $\mathrm{R}$ with the ggplot2 library as described previously (Catão et al., 2016). 


\section{Results}

Study sites and soils characteristics

Soil $\mathrm{NH}_{4}{ }^{+}-\mathrm{N}$ and $\mathrm{NO}_{3}^{-}-\mathrm{N}$ concentration, $\mathrm{pH}$ and water soil content were very similar in all 8 sites sampled in the two parks (Figure 3). The content of soil water, $\mathrm{NO}_{3}^{-}{ }^{-} \mathrm{N}, \mathrm{NH}_{4}{ }^{+}-\mathrm{N}$, and organic carbon, was measured in only one of the PNCV riverbank replicates due to the abundant presence of roots on the other replicates, which did not allow accurate measurements. The replicate of $\mathrm{MG}$ in $\mathrm{PNCV}$ had the highest $\mathrm{NH}_{4}{ }^{+}-\mathrm{N}$ and $\mathrm{NO}_{3}{ }^{-} \mathrm{N}^{-} \mathrm{NO}_{3}{ }^{-} \mathrm{N}$ was higher in the PESA MG than CD or SS, but no difference compared to FSD. pH was higher in the sites sampled in PNCV than PESA, but were not different within each park. However, MG sites from the two parks differed in $\mathrm{pH}$. Sites sampled in PESA did not differ in soil water content, but in PNCV, CL had higher soil water content than SS and CR. CR had the soil with the least water content in the two parks. Soil in the PNCV SS was slightly moister than the PESA SS.
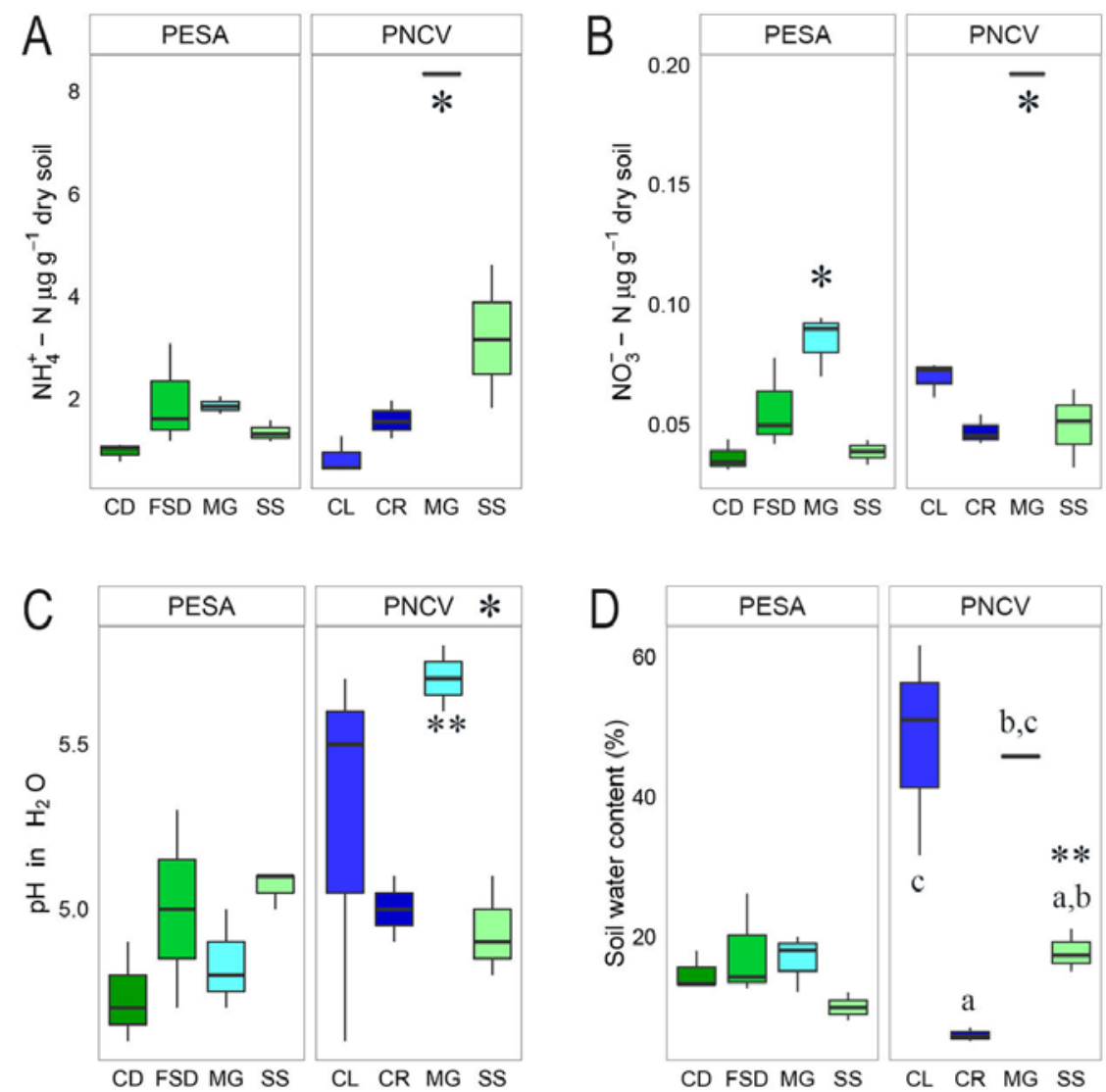

Figure 3. Boxplots on soils (A) $\mathrm{NH}_{4}{ }^{+}-\mathrm{N}$ and (B) $\mathrm{NO}_{3}^{-}-\mathrm{N}$ concentration, (C) $\mathrm{pH}$ and (D) water soil content. One-way ANOVA or T- tests with tukeyKramer post hoc tests to compare group means ( $R$ with the ggplot2 package) are represented with letters or with one asterisk (*) if only one site was significantly different from others. Two smaller asterisks (**) 
depict statistical difference between MG or between SS present in the two parks.

On the other hand, considering several physicochemical variables in a PCA, the two parks form segregated clusters (Figure 4). PNCV is a conservation unity representative of "Altitude Cerrado", at 1200 m of altitude approximately, oppositely to PESA, that is at 650 $\mathrm{m}$ altitude. As altitude masked the effect of other variables, it was not considered in the PCA. Besides altitude, $\mathrm{pH}$, clay (and sand), $\mathrm{C}$ content, $\mathrm{Al}^{+3}$, cation exchange capacity, $\mathrm{S}, \mathrm{Fe}, \mathrm{K}$ and other micronutrients as $\mathrm{B}, \mathrm{Cu}, \mathrm{Mn}$ and $\mathrm{Zn}$ differ between the sampled vegetation, and consequently create two clusters according to the two parks.

The parks have different soil texture, PESA presenting a greater clay content then PNCV, except for the Cerrado sensu stricto, which had the highest clay content within the PNCV sites (Figure 4). Therefore, clay content in both SS from the two parks were not different. On the other hand, MG from PESA had higher clay content than MG in PNCV. In PESA, CD had the highest clay content.

Carbon content was similar along the sites sampled, except on the MG in PNCV. The soil in this same site had the highest cation exchange capacity (CEC), which was significantly different from the MG site in PESA (Figure 4). Similarly, SS sites differed in CEC between parks. Sulfur concentration was different between parks, especially due to S concentration in $\mathrm{CL}$ and $\mathrm{MG}$ in PNCV. $\mathrm{Al}^{+3}$ concentration was high in all sites sampled, but significantly higher in the PNCV MG. On the other hand, Fe concentration changed between sites within each park: SS in PNCV had significantly higher Fe content. Similarly, MG and SS had higher Fe concentration than CD and FSD in the PESA. Furthermore, MG sites from the two parks differed in Fe concentration. 
A
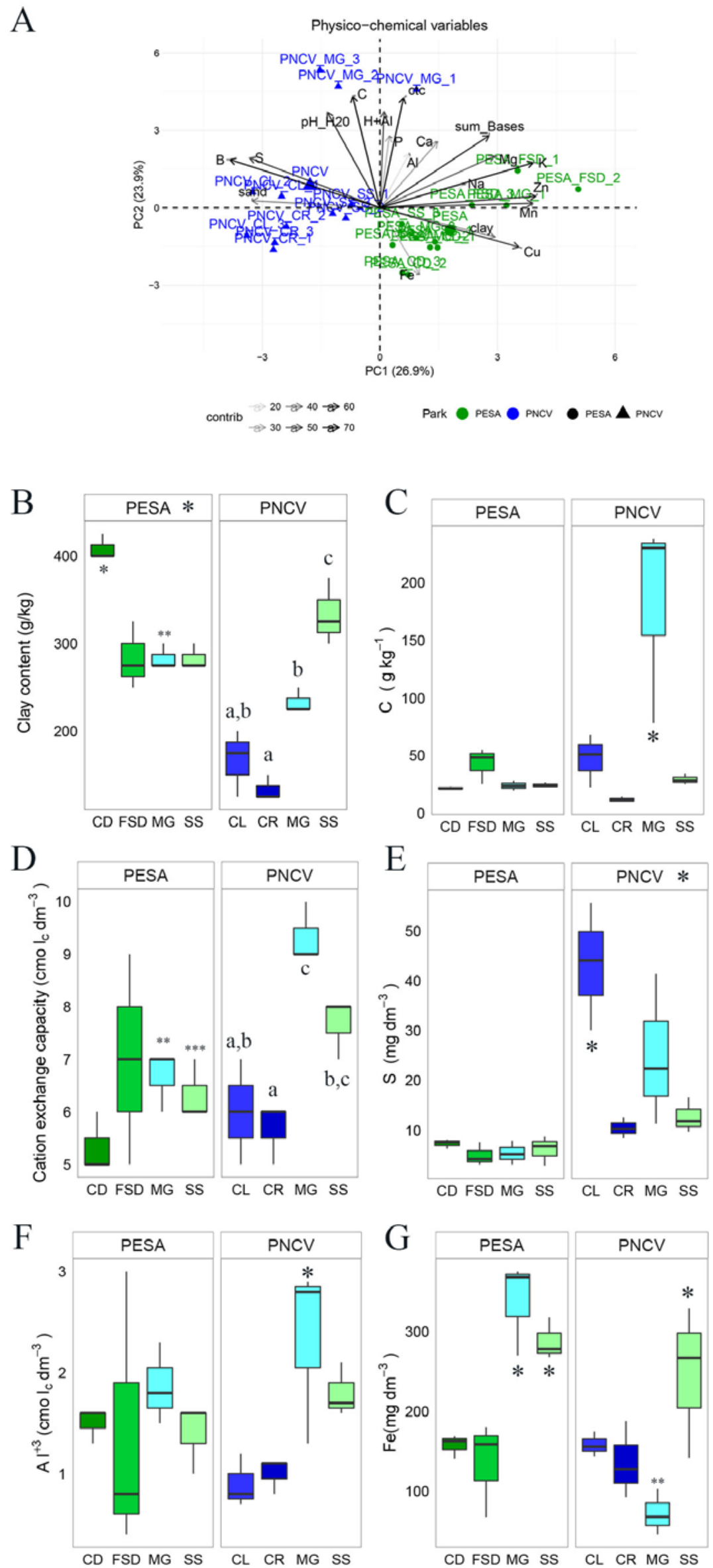
Figure 4. Soil physicochemical variables in the two parks and their sites. (A) Principal component analysis (PCA) of soil physicochemical properties based on a correlation matrix performed with $R$. Each vector points in the direction in which the respective value increases. Boxplots of soils (B) clay content, (C)C content, (D) cation exchange capacity, (E) $S$ concentration, (F) $\mathrm{Al}^{+3}$ concentration, (G) Fe concentration. One-way ANOVA or T- tests were performed in $R$. Tukey-Kramer post hoc tests to compare group means ( $R$ with the ggplot2 package) are represented with letters or with one asterisk $\left(^{*}\right)$ if only one site was significantly different from others. Two (or three) smaller asterisks depicted statistical difference between MG or between SS present in the two parks.

Phylogenetic and functional analyses

A total of 1,364,104 sequences were obtained from PNCV and 992,685 from PESA; an average of 7 and $11.7 \%$ did not pass on the quality control, respectively (Table S1), and 2.7 to $8.7 \%$, respectively, were considered sequences' replicates and were excluded from the analysis. The percentage of sequences annotated to known protein was $61.4( \pm 3.5) \%$ and 46.5 ( \pm 1.4 ) \% for the PNCV and the PESA, respectively, and only a small fraction (around $0.5 \%$ ) of the reads was annotated as ribosomal, or to the $\mathrm{N}$ metabolism (around 1\%).

The number of ribosomal sequences annotated varied from 88 to 775 and taxonomical assignment was against the non-redundant protein M5NR database. According to this database, most of the genes annotated were from Bacteria (around 97\%), with the remaining being part either of the Domain Archaea (0,9\%), the Domain Eukarya (1,6\%) or unknown (0,18\%). Archaea was mainly present in soil as Thaumarchaeota and Crenarchaeota; CR and MG from PNCV and FSM and SS from PESA - presented low values of Euryarchaeota. The most abundant phyla in the Bacteria domain were Actinobacteria, Proteobacteria and Firmicutes, especially the class Bacilli, Clostridia (both from Firmicutes), $\alpha$-Proteobacteria, $\beta$-Proteobacteria and $\gamma$-Proteobacteria. Ascomycota, Basidiomycota, Streptophyta and Arthropoda were within the most Eukarya annotated sequences.

Contrary to the PCA constructed with the physicochemical variables, the PCA representing the phylum relative abundance shows no separation between the parks (Figure 5). The vectors point to a greater relative abundance present in some of the replicates as for example Proteobacteria and Spirochaetes for the Campo limpo site at the PNCV. 


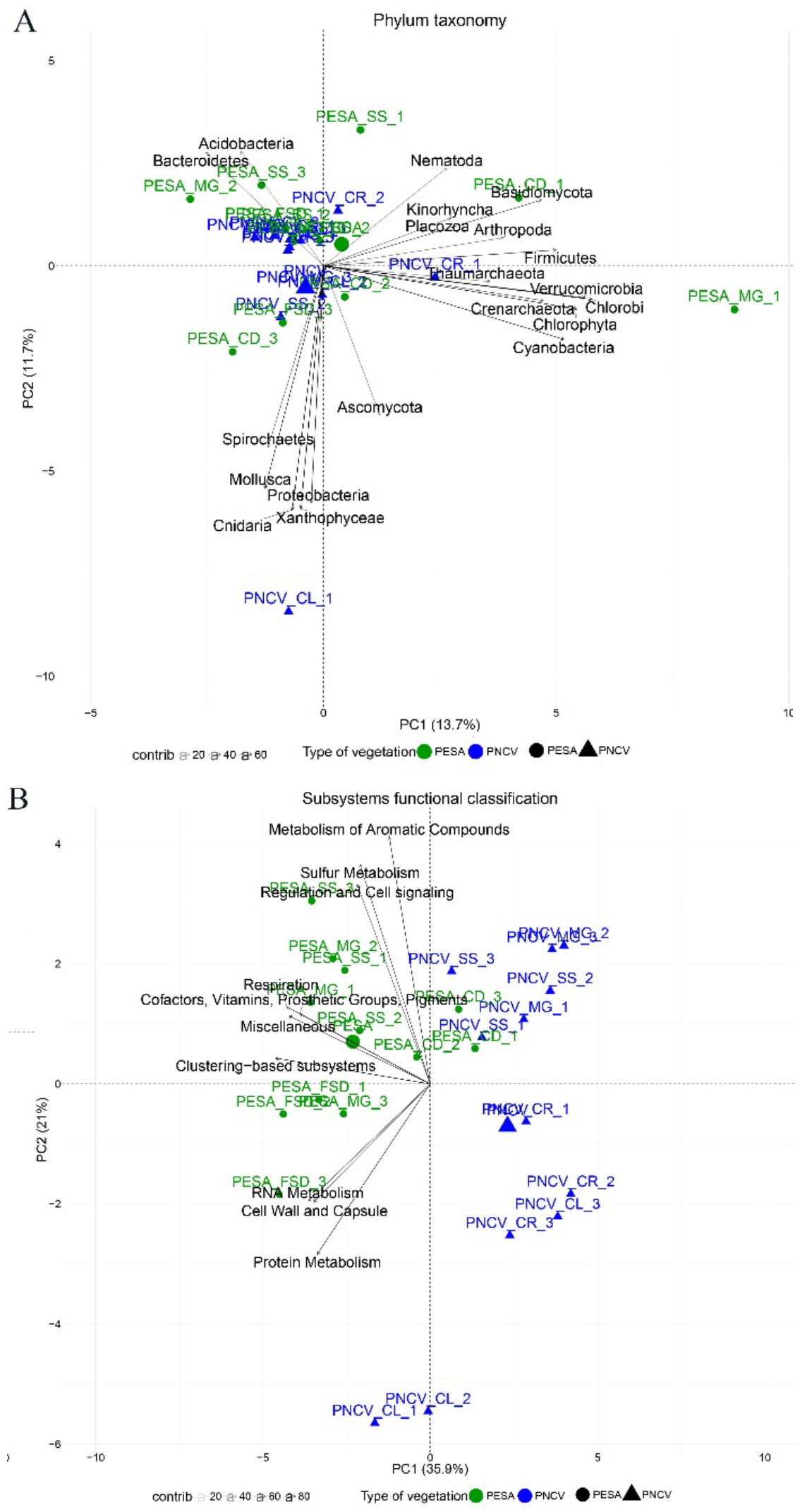

Figure 5. Principal component analysis (PCA) constructed with the relative abundance of annotated genes for (A) phylogenetic assignment of phyla and (B) subsystems functional classification based on a correlation matrix performed with $\mathrm{R}$. Each vector points in the direction in which the respective value increases. 
Distribution of the relative abundance of the SEED subsystems classification presents a greater separation of sites sampled in each park (Figure $5 \mathrm{~B}$ ). PESA presented significantly higher relative abundance than PNCV for most of the subsystems as seen in the PCA, but more specifically for respiration ( $p$-value=0.014), potassium metabolism ( $p$ value<0.0001) and phages, prophages, transposable elements and plasmids ( $p$ value $=0.044$ ) (Figure 6). On the other hand, PNCV had more virulence, disease and defense ( $p$-value<0.0001) annotated sequences than PESA. Despite the broad potential for metagenomes analysis, this work focused on the nitrogen metabolism. 

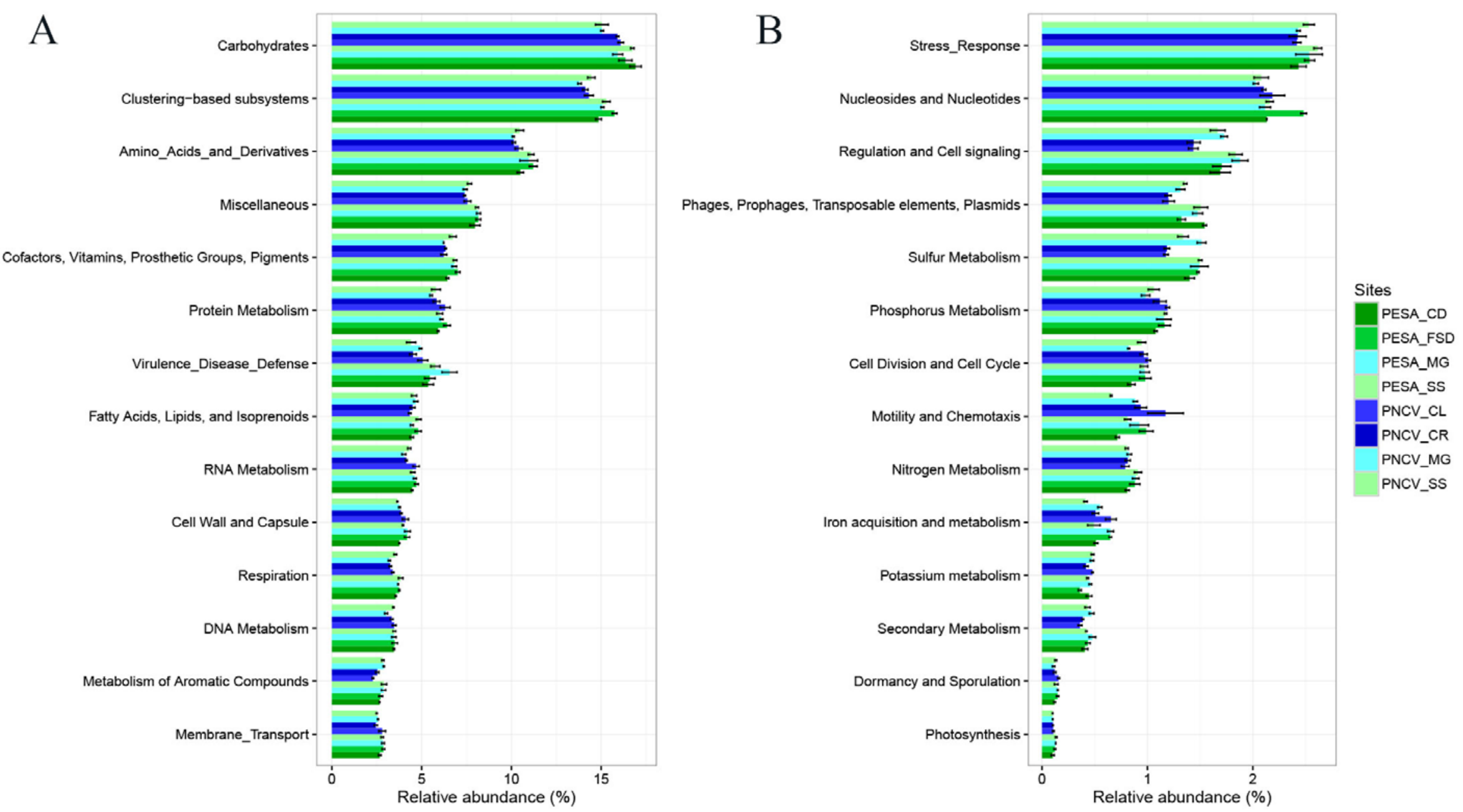

Figure 6. Bar plots for the relative abundance of SEED subsystems according to each site $\times$ park. (A) Most abundant SEED subsystems, (B) less abundant SEED subsystems. 
The greatest part of annotated genes to $\mathrm{N}$ metabolism were related to the ammonia assimilation (37\%), followed by nitrate and nitrite ammonification (17\%), nitric oxide synthase (12\%) and allantoin utilization ( $9 \%$ ) as shown in Figure 7 that concatenates all genes annotated to $\mathrm{N}$ metabolism in the 24 metagenomes. The arrows are proportional to the number of genes annotated in our metagenomes. The least abundant were the cyanate hydrolysis (6\%), the denitrification (5\%), the dissimilatory nitrite reductase $(5 \%)$, the nitrogen fixation (4\%), the nitrosative stress (4\%) and some genes related to the amidase clustered with urea and nitrile hydratase functions ( $1 \%)$ and nitrilase subsystems $(<1 \%)$. Only two hits were found for ammonia monooxygenase, which is an enzyme part of nitrification process, but classified in the transport system according to SEED subsystems. No nitrite oxidoreductase was detected in the metagenomes, therefore both ammonia and nitrite oxidation were represented by slim arrows.

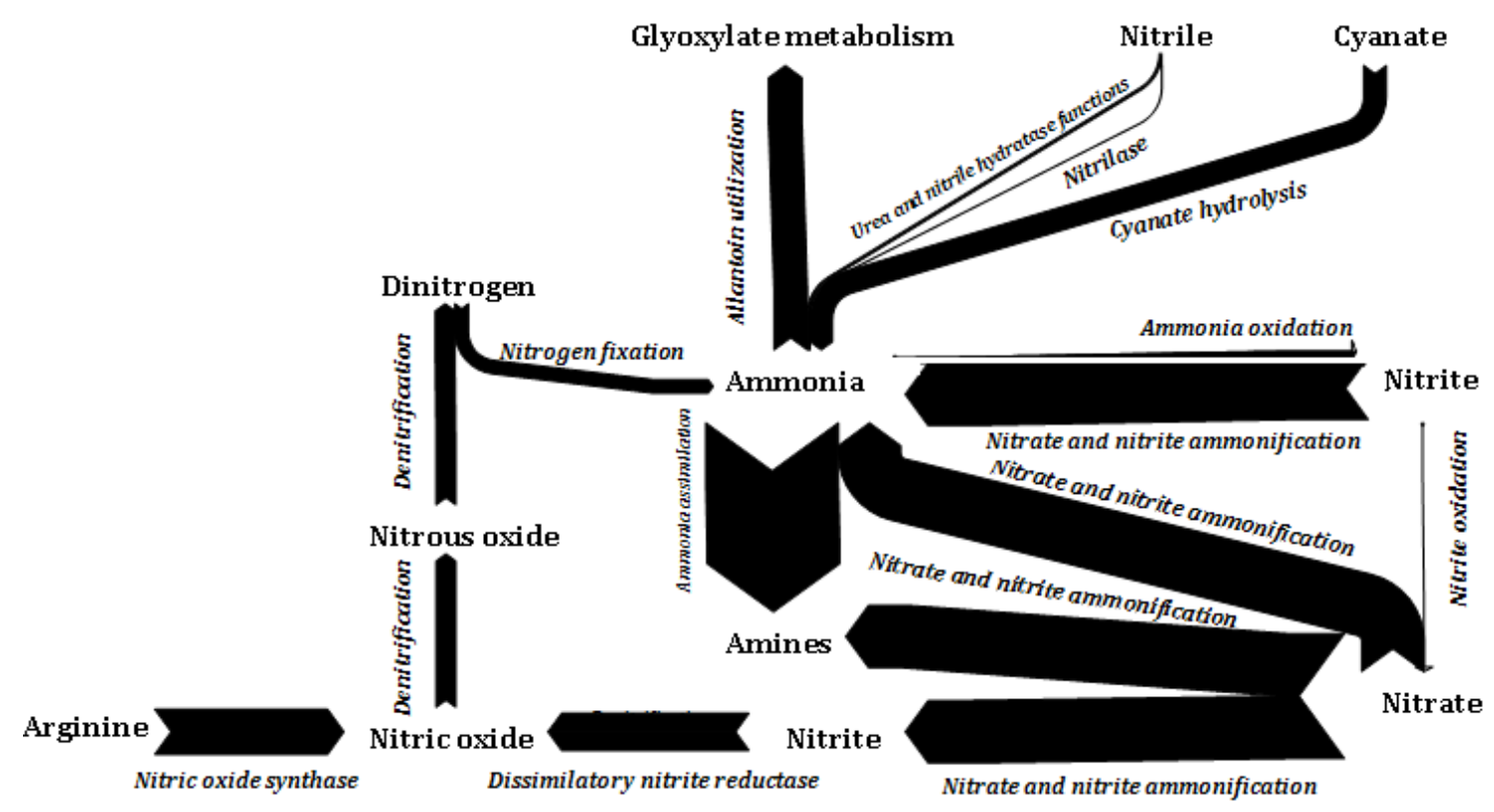

Figure 7. Schematic representation of the $\mathrm{N}$ cycle according to the SEED subsystems annotated genes performed with e!Sankey 2. The total number of genes annotated from PESA and PNCV metagenomes. The arrows are proportional to the number of genes annotated for each process.

PNCV and PESA were not different for the annotated genes of $\mathrm{N}$ metabolisms, except for the ammonia assimilation metabolism, as PNCV had significantly (pvalue $=0.01727$ ) lower relative abundance than PESA (Figure 8). Ammonia assimilation was mainly represented by ammonium transporter, glutamate synthase and glutamine synthetase type I. No other N-related metabolism was different between parks. Likewise, 
the Cerrado sensu stricto (SS) and the Mata de galeria (MG- riverbank) from both parks had similar relative abundance for the $\mathrm{N}$ processes displayed in Figure 8 . The process of input of nitrogen to the soil system through nitrate and nitrite ammonification (genes for assimilatory nitrate reductase and nitrate/nitrite transporters) was not different between parks, but within the PNCV, the Campo limpo site was significantly lower from the Cerrado rupestre ( $p$-value=0.0237). In contrast, Campo limpo soil had the highest relative abundance of genes annotated for nitrogen fixation ( $p$-value=0.0249), represented by genes for nitrogenase. Similarly, Mata de galeria in PESA had higher annotated genes for denitrification than Campo sujo ( $p$-value=0.0202), and higher annotated genes for nitrosative stress than Campo sujo and Floresta semi-decídua ( $p$-value=0.0117). Denitrification process includes genes for nitrite, nitric oxide and nitrous oxide reductases. In all soils, the copper nitrite reductase was found, usually monitored by the nirk gene, but only in one soil from PNCV we could detect the cytochrome cd1 nitrite reductase. Annotated genes for the nitric oxide reductase quinol-dependent were significantly more numerous than other denitrification genes. Nitrosative stress, denoted by anaerobic nitric oxide reductase flavorubredoxin and hydroxylamine reductase, was also higher in the PNCV Campo limpo than Cerrado sensu stricto and Mata de galeria ( $p$-value=0.00622). 

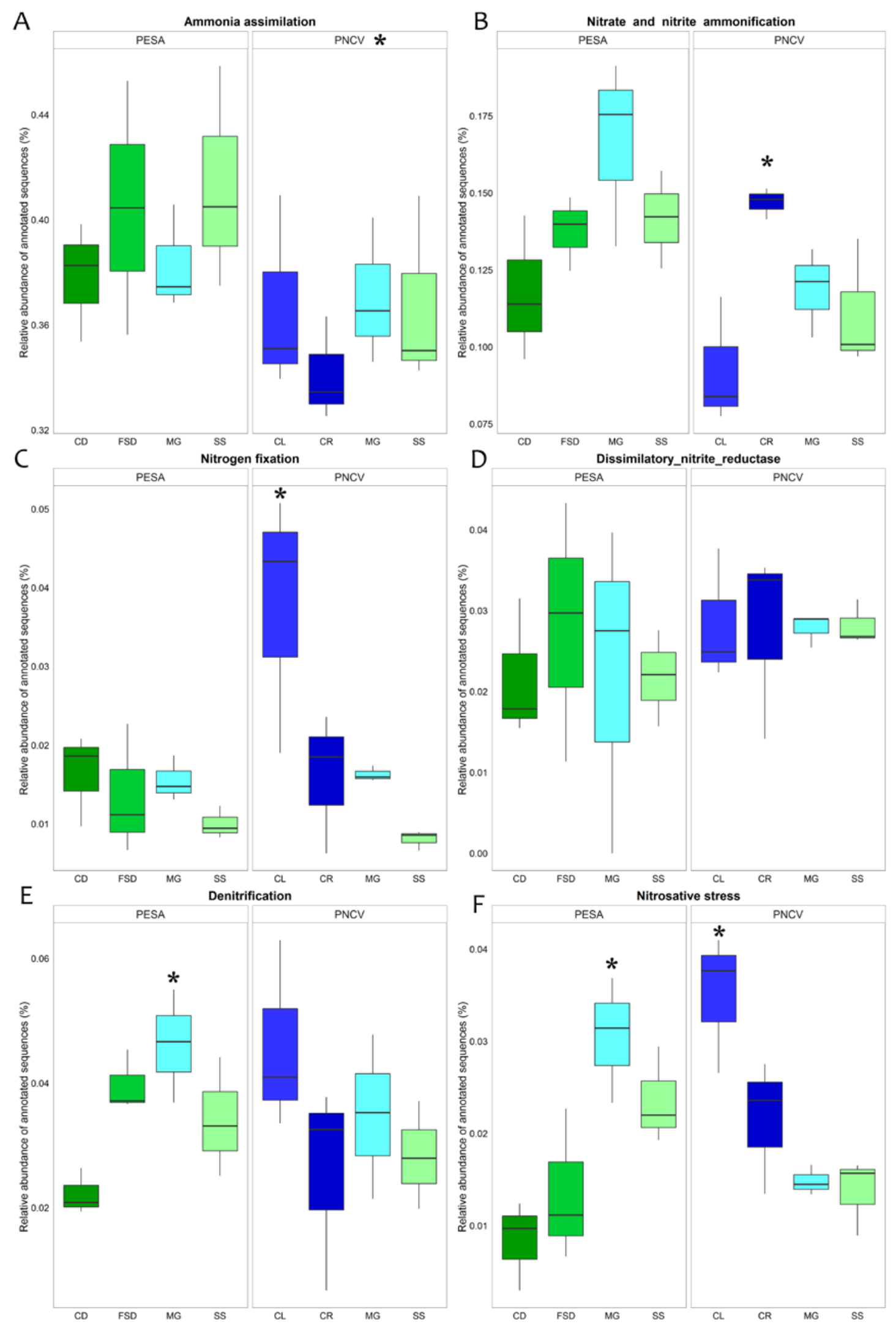

Figure 8. Boxplots of soils (A) ammonia assimilation, (B) nitrate and nitrite ammonification, $(C)$ nitrogen fixation, (D) dissimilatory nitrite reductase, $(E)$ denitrification, $(F)$ nitrosative stress. One-way ANOVA or T- tests were performed in R. Tukey-Kramer post hoc tests to compare group means ( $\mathrm{R}$ with the ggplot2 package) are represented with one asterisk (*). 


\section{Discussion}

Here we present the first metagenomic description on the $\mathrm{N}$ cycling functional and phylogenetic genes from Cerrado soils microbiota in Central Brazil. This biome is composed by a gradient of trees/shrubs layer ranging from grasslands to forests and savannas. Analysis of phospholipid fatty acids and 16S rRNA genes have showed that vegetation cover influences the soil taxonomic microbial composition (Araujo et al., 2012; Mendes et al., 2012; Viana et al., 2011). Nevertheless, our first hypothesis was rejected, since we could not find patterns that explained distribution of functional guilds according to the macro distribution of Cerrado's vegetation.

The types of vegetation sampled here differed in terms of soil physicochemical variables and were more similar within each park. The world literature shows $\mathrm{pH}$ as the factor that better explains soil microbial distribution (Lauber et al., 2009). Though, for the Cerrado it has been shown that the first rains on the beginning of the rainy season or experimentally the addition of water promote greater difference on the microbial community either with increase on microbial biomass (da Silva, 2004; Nardoto and Bustamante, 2003), microbial activity and nitrification rates (da Silva, 2004), or change on the bacterial composition with the transition between the dry and rain seasons (Bresolin et al., 2010; Nardoto and Bustamante, 2003; Pinto et al., 2006). Furthermore, water effect on the microbial community masks the fire effect (Viana et al., 2011). Truly, water promoted a change in the microbial community performing the $\mathrm{N}$ cycling, particularly in the Campo limpo. This confirms our second hypothesis that considers a variation in $\mathrm{N}$ metabolism according to soil characteristics between types of vegetation.

In fact, the soils in the PNCV had higher $\mathrm{pH}$ and S concentration than soils in PESA, which, in turn, presented higher clay content. However, no significant correlation was observed between $\mathrm{pH}$ and phylogenetic or functional genes relative abundance. Microbial community described with these metagenomes seem to differ more due to soil characteristics than the type of vegetation or the geographic distance. The similarity found between the Cerrado sensu stricto (SS) and the Mata de galeria (MG- riverbank) from both parks refutes the hypothesis of geographical differentiation between islands of Cerrado distant from each other in terms of soil microbial community. On the other hand, it reinforces the observed differences accordingly to type of soil and vegetation.

Assuming that types of vegetation would influence microbial distribution, the MG sites from the two parks should be similar within each other and with the FSD, as they are 
forest formations. However, they should be less similar to the savanna sites - SS and CR - or the sites with predominant herbaceous layer as the CS and the CD. On the other hand, geographic distance is informative, since microbial communities are similar in the parks, and are distant $500 \mathrm{~km}$, therefore, there is an indication that Cerrado biome has a particular soil microbial community. This will have to be confirmed in a biogeographical model, as for example the use of mantel test with other Cerrado areas and other biomes.

As microbes are confined to a thin layer of water in the soil particles, it is reasonable to think that water is the major limitation of prokaryotic life in soil (Fenchel, 2012). The soil texture influences the water retention according to the percentage of clay, sand and silt particles, which has an impact on the gravimetric soil water content and consequently on the microbial community. The Cerrado rupestre was the driest soil sampled with the greater composition of sand in comparison to clay. This type of vegetation is only present in some fragments of the biome Cerrado specially in higher altitudes between 800 and $2000 \mathrm{~m}$, characterized by rocky outcrops with high vegetal endemism and usually found in Leptosols (neossolos litólicos, Brazilian soil classification). The metagenomes found in this vegetation had the greatest $\alpha$-diversity of Shannon (data not shown), potentially a greater diversity in response to the nutrient and water stress.

The theory of pore connectivity favors the idea that low contact between organisms because of low water potential allows for greater microbial diversity (Carson et al., 2010). However, in the metagenomes, both the $C R$ and the $C L$ presented the highest Shannon diversities and they have also the two most distinct soil water content. Therefore, we considered that in this case, the higher diversity is due to disturbance (water lodging in the case of $\mathrm{CL}$ ) promoting stochasticity for different groups to prevail instead of a higher abundance of one or another set of microorganisms.

Bacteria was the predominant domain of annotated sequences as expected because of this domain abundance in soil, the technique and the databases, and as described in the literature (Delmont et al., 2012; Fierer et al., 2012a). The phyla more abundant in these soils were Actinobacteria, Proteobacteria and Firmicutes. However previous work on Cerrado samples had shown by $16 \mathrm{~S}$ rRNA pyrosequencing that the Acidobacteria was the most abundant phyla (Araujo et al., 2012). These contrasting results might be because of the two different techniques used and may be an indicative of the amplicon sequencing bias as the taxonomic classification of the metagenomes here was produced by the annotation of all sequences against the protein non-redundant database M5NR. It can be also that the soil samples used in that work were different from the one 
used here, since Fierer et al. showed a high correlation $\left(r^{2}=0,81, p<0,001\right)$ of $16 \mathrm{~S}$ rRNA and metagenomic results from soil samples of different types of biomes (Fierer et al., 2012b).

The greater number of the Actinobacteria and Firmicutes found here might be associated to organic matter degradation, especially Actinobacteria which are able to degrade high C:N ratio organic matter as those found in Cerrado soils (Nardoto and Bustamante, 2003). Actinobacteria are also related to the antibiotic and secondary metabolic production (Gomes et al., 2000; Petinate et al., 1997) and have genes involved on ultraviolet and hydric stress (LeBlanc et al., 2008) besides the apparent resistance to heavy metals (Gremion et al., 2003) that might be an interesting characteristic considering the high aluminum content present on Cerrado soils.

Cerrado soils are typically $\mathrm{N}$-limited, with a higher concentration of $\mathrm{NH}_{4}{ }^{+}$than $\mathrm{NO}_{3}{ }^{-}$ (Bustamante et al., 2006; Nardoto and Bustamante, 2003). In addition, Nardoto and Bustamante (2003) observed during the rainy season an increase of mineralization and nitrification rates, but inorganic nitrogen concentration decreased (Nardoto and Bustamante, 2003), which could be interpreted as an assimilation of $\mathrm{N}$ by the vegetation. This corroborates the high percentage of ammonia assimilation genes annotated in the metagenomes (37\%), that was significantly different between the parks, although these did not show a significant difference for $\mathrm{NH}_{4}{ }^{+}-\mathrm{N}$ concentration. Ammonia assimilation collected genes for the enzymes related to glutamate and glutamine synthase pathways (EC 1.4.1.13 and EC 6.3.1.2, respectively). These enzymes use one molecule of ammonia to synthesize central amines for the cell and were specially related to Bacteria, but also in Archaea, Cyanobacteria, Ascomycota and Streptophyta sequences.

Moreover, only two ammonia monooxygenase were retrieved in the annotated genes in the transporter membrane subsystem, which is also corroborated with the literature that suggests low levels of nitrate in Cerrado soils and correspondent low levels of nitrification rate (Bustamante et al., 2006; Nardoto and Bustamante, 2003). Nitrification genes were absent in other metagenomes from Brazilian mangroves sediments (Andreote et al., 2012). These AMO genes are potentially from genomes of Methylococcus, a methane oxidizing bacterium able to ammonia oxidation (Dalton, 1977). Although, 2 hits are too low to take conclusions from, further studies should consider amoA and pmoA comparison in Cerrado soils.

This is also validated by the low abundance of ammonia oxidizers detected with qPCR ( $10^{+3}$ to $10^{+5}$ amoA gene abundance $\mathrm{g}^{-1}$ soil) in undisturbed Cerrado soils (Catão et al., 2016). Therefore, the low detection of genes for nitrification in the metagenomes was most 
likely due to depth of sequencing. Another study with Cerrado metagenomes sequenced with Ion torrent technology (mean 2.326.852 annotated genes) obtained an average of 3 ammonia monooxygenases in native soil compared to 30 and 34 hits for no-tillage and conventional tillage, respectively (Souza et al., 2015). These were from Archaea (Thaumarchaeota, Nitrosopumilales) and Bacteria from Alfa- (Rhodospirillales), Beta(Burkholderiales and Nitrosomonadales) and Gamma-Proteobacteria (Pseudomonadales, Methylococcales).

In order to ammonia to be available $\mathrm{No}_{3}{ }^{-}$and $\mathrm{No}_{2}{ }^{-}$can be reduced to $\mathrm{NH}_{4}{ }^{+}$in a process called ammonification, that corresponded to $17 \%$ of genes related to the $\mathrm{N}$ metabolism in the metagenomes. These were in majority nitrate transporters, nitrate (EC 1.7.99.4) and nitrite reductases (EC 1.7.1.4) from bacteria, although another work found these from plants and fungi in snowpacks (Larose et al., 2013). In soil the greatest part of inorganic $\mathrm{N}$ is made available through mineralization from soil organic matter, and nitrification was thought to be inhibited in the acidic Cerrado soil (Catão et al., 2016). Further studies should evaluate nitrate absorption, since little nitrate accumulation in soil might be a result of a rapid assimilation after nitrification.

In the Cerrado soils, 16 to $44 \mathrm{~kg}$ of $\mathrm{N} \mathrm{ha}^{-1}$ year $^{-1}$ enter the lithosphere via biological $\mathrm{N}$ fixation, constituting the main form of input of $\mathrm{N}$ in the lithosphere, compared to $\mathrm{N}$ deposition (Cleveland et al., 1999). $\mathrm{N}$ fixation is responsible for the rates of $\mathrm{N}$ cycling in the Cerrado ecosystems together with type of vegetation, fire frequency and land use modification (Bustamante et al., 2012C). The metagenomes showed that $4 \%$ of the total of $\mathrm{N}$ metabolism annotated genes were of $\mathrm{N}$ fixation genes, and significantly higher number of genes were annotated in the Campo limpo than in the other vegetation types. Bradyrhizobium genera and other from Rhizobiales family had been already described in a Cerrado native soil (Araujo et al., 2012). Moreover, the lower values of genes for ammonification in the Campo limpo might be a confirmation the input of $\mathrm{N}$ as $\mathrm{N}_{2}$ to this system, as presented by a significantly higher abundance of $\mathrm{N}$ fixation genes. Similarly, the increase in water content in the Campo limpo was possibly related with the higher abundance of genes for nitrosative stress.

Despite the numerous species of the Fabaceae family (around 780 species) found in the Cerrado (Filgueiras, 2002), known to comprise leguminous species, the Campo limpo here sampled is a grassland. Furthermore, few works have measured the nodular activity in these associations (for revision see (Bustamante et al., 2012C)). In fact, Bradyrhizobium are abundant in soils that lack leguminous plants (VanInsberghe et al., 2015). These authors 
described the high abundance of a Bradyrhizobium OTU that lacks nif and nod genes, and suggest this is a group of free-living ecotypes with potential aromatic degradation role (VanInsberghe et al., 2015). Contrarily, Campo limpo metagenomes have nitrogenase genes, suggesting potential activity of nitrogen fixation in these soils, most likely of free-living rhizobia.

As described above, mineralization and nitrification rates are greater during the first rains on the rainy season (Nardoto and Bustamante, 2003). Recently it was proposed that climate change will impact the rain frequency and increase the length of the dry season (Bustamante et al., 2012c), which might result in changes on the $\mathrm{N}$ cycle balance and fluxes in the Cerrado ecosystems and $\mathrm{N}$ trace gas emission. These are produced during nitrification and denitrification. Denitrification is a modular process responsible for the return of $\mathrm{N}_{2}$ to the atmosphere and is favored in anaerobic environments (Graf et al., 2014), but have been described in dry soils (Braker et al., 2015). This trait is not centered in few clusters as the nitrification step of the nitrogen cycle, but spread within phylogenetic groups of heterotrophic organisms capable of reducing nitrate and nitrite.

Although the annotated denitrifying genes indicates that these process might be occurring in Cerrado soil particles microhotspots, $\mathrm{N}$ trace gases were not measured in this work. In previous studies, low $\mathrm{N}$ gas emissions detected in Cerrado soils were shown to be influenced by the type of vegetation and soil water gravimetric content (Pinto et al., 2002). Water addition resulted in an increase of $100 \times$ on NO emissions in a Campo sujo site (Pinto et al., 2002), but $\mathrm{N}_{2} \mathrm{O}$ emissions in the Cerrado are almost always under the detection limit (Bustamante et al., 2006). In the metagenomes we found all the enzymes required to denitrification: nitrite reductase (often measured by the genes nirK, nirS), nitric oxide reductase (referred to the gene norB), nitrous oxide reductase (measured by the presence of nosZ gene). The copper nitrite reductase (nirK gene) was significantly more abundant than its cytochrome cd1 nitrite reductase counterpart (nirS), as showed for other soils previously (Jones et al., 2014) and in another study in the Cerrado (Souza et al., 2015). In most of bacterial genomes, organisms that hold nirK do not possess nirS and vice-versa, and seems that these nirk and nirS denitrifiers respond differently to environmental gradients (Graf et al., 2014). In the same way as other soils (Jones et al., 2014), the abundance of nitrous-oxide reductase genes was lower than that for nitric-oxide reductase genes. Soil sink capacity for $\mathrm{N}_{2} \mathrm{O}$ was related especially with the presence of nos $\mathrm{Z}$ denitrifiers of clade II, but the greater diversity of both clades I and II, the greater capacity of soil to reduce $\mathrm{N}_{2} \mathrm{O}$ in excess (Jones et al., 2014). 
Genes for nitric oxide production from arginine were detected as $12 \%$ of genes annotated for the nitrogen metabolism. Another indicative of denitrifiers activity in Cerrado soils is the presence of nitrosative stress genes ( $4 \%$ of total nitrogen metabolism). This stress is promoted by high exposure of cells to nitric oxide or oxidant peroxinitrite, formed by the interaction of NO with superoxide anions. NO inhibits cell respiration and can react with multiple cell components in both prokaryotic and eukaryotic cells (Poole, 2005) and it is toxic for organisms sharing the habitat with denitrifiers (Choi et al., 2006). The flooded grassland had the greatest number of enzymes related to the nitrosative stress process probably as a consequence of the anaerobic environment with higher water gravimetric content than the other Cerrado sites. On the other hand, MG from PESA had significant higher annotation of denitrification genes than other PESA sites, which was not correlated with the soil water content.

Metagenomes studies do not discuss why so often denitrification genes are annotated but fewer or none of nitrification genes are identified in the metagenomes. Some hypotheses are proposed here: 1) as denitrification is a polyphyletic characteristic, genes are widespread and have higher probability to be found, but are not necessarily active; 2) nitrification in Cerrado soils is performed by heterotrophic organisms also able to denitrify so nitrate does not accumulate (Kuenen and Robertson, 1994); 3) databases are less complete for nitrification genes than denitrification. The last assumption was tested by performing a blast of all metagenomes here sequenced against a specific amoA database (Pester et al., 2012), and no results were found. Further studies should consider investigating heterotrophic nitrification and nitrifier-denitrification in Cerrado soils. The amoA gene used to monitor ammonia oxidizers targets only autotrophic organisms. One study performed in a Cerrado soil, using an inhibitor (e.g. acetylene) for the autotrophic AMO complex suggested that nitrifiers in those soils were heterotrophic (Poth et al., 1995).

These results are the first set of metagenomic data representing the relative abundance of microbial genes for the $\mathrm{N}$ metabolism between different types of vegetation and soils from undisturbed areas in the Cerrado biome. These data will be important to understand the impact of land use change on soil microbiota on this Brazilian savanna and consequently in the ecological processes by them produced. Further investigation with these metagenomes will focus on CAZymes database, to search for specific genes related with organic matter cycling, testing again the hypothesis of difference between types of vegetation and their $\mathrm{C}$ and $\mathrm{N}$ input to the litter and soil. 
Supplementary Information

Table 3. Coordinates and altitude of each sampled site

\begin{tabular}{|c|c|c|c|c|c|}
\hline Park & Type & Replicate & Coordinates & & Altitude \\
\hline & & & $\mathrm{S}$ & W & (m) \\
\hline \multirow{12}{*}{ PNCV } & MG & 1 & $14^{\circ} 06.258^{\prime}$ & $47^{\circ} 42.419^{\prime}$ & 1194 \\
\hline & MG & 2 & $14^{\circ} 06.246^{\prime}$ & $47^{\circ} 42.428^{\prime}$ & 1170 \\
\hline & MG & 3 & $14^{\circ} 06.174^{\prime}$ & $47^{\circ} 42.462^{\prime}$ & 1159 \\
\hline & $\mathrm{CL}$ & 1 & $14^{\circ} 06.529^{\prime}$ & $47^{\circ} 42.879^{\prime}$ & 1202 \\
\hline & $\mathrm{CL}$ & 2 & $14^{\circ} 06.504^{\prime}$ & $47^{\circ} 42.888^{\prime}$ & 1194 \\
\hline & $\mathrm{CL}$ & 3 & $14^{\circ} 06.480^{\prime}$ & $47^{\circ} 42.883^{\prime}$ & 1196 \\
\hline & SS & 1 & $14^{\circ} 07.128^{\prime}$ & $47^{\circ} 43.865^{\prime}$ & 1186 \\
\hline & SS & 2 & $14^{\circ} 07.109^{\prime}$ & $47^{\circ} 43.893^{\prime}$ & 1184 \\
\hline & SS & 3 & $14^{\circ} 07.117^{\prime}$ & $47^{\circ} 43.921^{\prime}$ & 1185 \\
\hline & $C R$ & 1 & $14^{\circ} 05.499^{\prime}$ & $47^{\circ} 42.265^{\prime}$ & 1187 \\
\hline & $C R$ & 2 & $14^{\circ} 05.473^{\prime}$ & $47^{\circ} 42.271^{\prime}$ & 1190 \\
\hline & $C R$ & 3 & $14^{\circ} 05.454^{\prime}$ & $47^{\circ} 42.273^{\prime}$ & 1185 \\
\hline \multirow{12}{*}{ PESA } & MG & 1 & $15^{\circ} 50.392^{\prime}$ & $52^{\circ} 14.791^{\prime}$ & 555 \\
\hline & MG & 2 & $15^{\circ} 50.398^{\prime}$ & $52^{\circ} 14.790^{\prime}$ & 516 \\
\hline & MG & 3 & $15^{\circ} 50.412^{\prime}$ & $52^{\circ} 14.771^{\prime}$ & 507 \\
\hline & $\mathrm{CS}$ & 1 & $15^{\circ} 49.700^{\prime}$ & $52^{\circ} 13.835^{\prime}$ & 718 \\
\hline & CS & 2 & $15^{\circ} 49.675^{\prime}$ & $52^{\circ} 13.816^{\prime}$ & 723 \\
\hline & CS & 3 & $15^{\circ} 49.654^{\prime}$ & $52^{\circ} 13.810^{\prime}$ & 713 \\
\hline & FSM & 1 & $15^{\circ} 51.118^{\prime}$ & $52^{\circ} 14.854^{\prime}$ & 617 \\
\hline & FSM & 2 & $15^{\circ} 51.112^{\prime}$ & $52^{\circ} 14.827^{\prime}$ & 621 \\
\hline & FSM & 3 & $15^{\circ} 51.095^{\prime}$ & $52^{\circ} 14.796^{\prime}$ & 654 \\
\hline & SS & 1 & $15^{\circ} 50.906^{\prime}$ & $52^{\circ} 14.393^{\prime}$ & 705 \\
\hline & SS & 2 & $15^{\circ} 50.919^{\prime}$ & $52^{\circ} 14 \cdot 417^{\prime}$ & 713 \\
\hline & SS & 3 & $15^{\circ} 50.933^{\prime}$ & $52^{\circ} 14.441^{\prime}$ & 709 \\
\hline
\end{tabular}



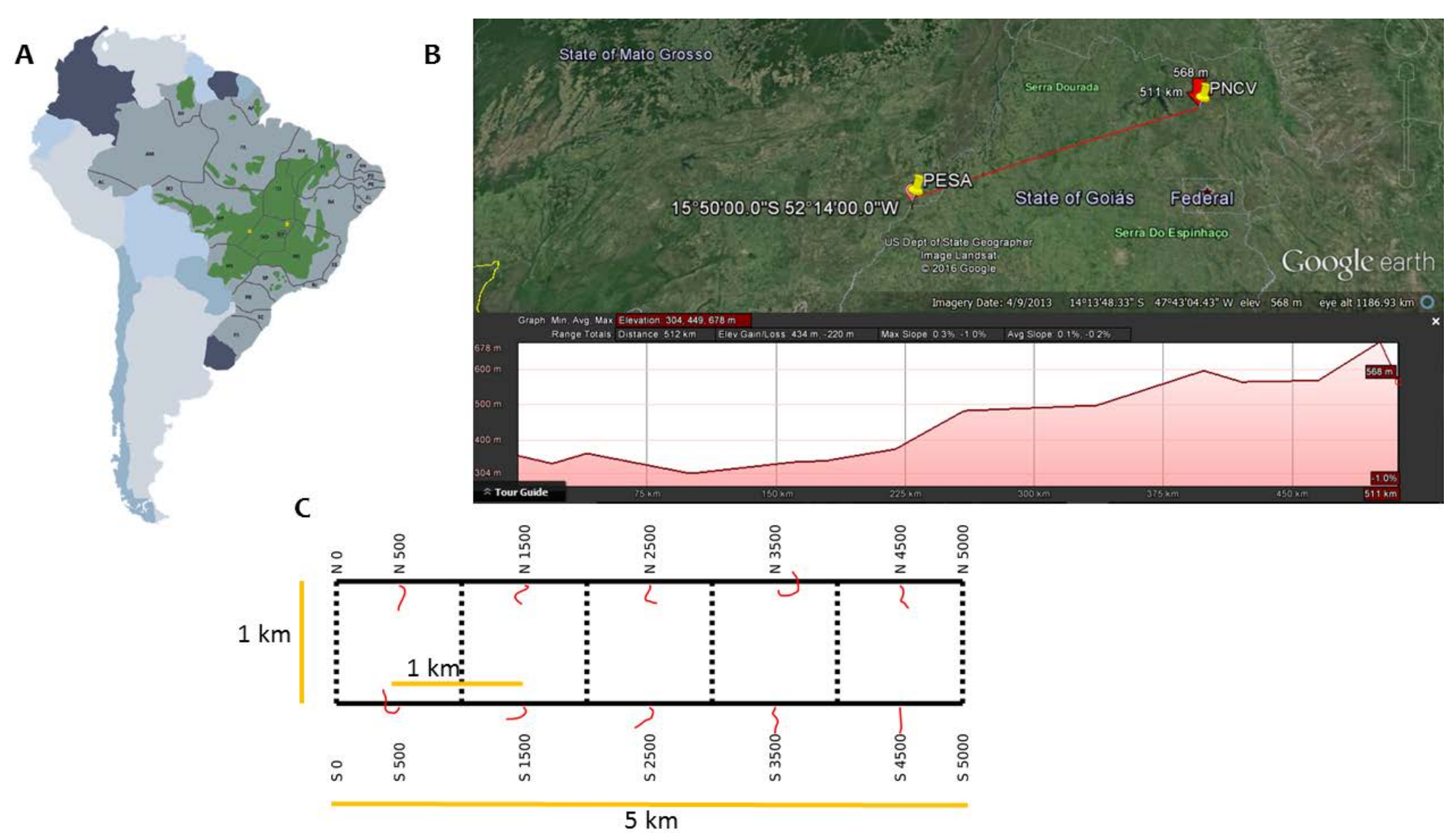

Figure 9. (A) Representation of the map of South America with Brazil highlighted in blue and the Cerrado biome in green. Yellow points represent the (B) sampled parks PESA and PNCV marked in the Google Earth photography. The elevation gradient shows a difference of $568 \mathrm{~m}$ and $511 \mathrm{~km}$ between parks. (C) Module experimental design scheme (figure adapted from the document of standard protocol for sampling within the Rede ComCerrado), 5 $\mathrm{km}$ long transects, separated by $1 \mathrm{~km}$ and each sampling parcel draw in red. Red lines for the parcels are not straight because they follow the local topography. 
Table 4. Number of sequences for each metagenome, their identification and the number of reads that passed QC, that were annotated and to the $\mathrm{N}$ metabolism

\begin{tabular}{|c|c|c|c|c|c|c|c|c|c|c|}
\hline MG-Rast & Site ID & $\begin{array}{c}\text { Vegetation } \\
\text { type }\end{array}$ & $\begin{array}{l}\text { raw } \\
\text { reads }\end{array}$ & after QC & $\%$ & mean length & $\begin{array}{c}\text { annotated } \\
\text { seqs }\end{array}$ & $\%$ after QC & $\begin{array}{c}\text { annotated in N } \\
\text { metabolism } \\
\text { subsystems }\end{array}$ & $\begin{array}{c}\% \text { of } \\
\text { annotated }\end{array}$ \\
\hline 4530784.3 & N500_1 & & 70230 & 62300 & 88.7 & $520+-228$ & 42037 & 67.5 & 355 & 0.8 \\
\hline 4530785.3 & N500_2 & \multirow{3}{*}{$\begin{array}{l}\text { Cerrado } \\
\text { rupestre }\end{array}$} & 112118 & 99061 & 88.4 & $499+-227$ & 58910 & 59.5 & 467 & 0.8 \\
\hline 4530786.3 & N500_3 & & 130778 & 115537 & 88.3 & $505+-227$ & 79126 & 68.5 & 657 & 0.8 \\
\hline 4530787.3 & S1500_1 & & 155186 & 137419 & 88.6 & $520+-227$ & 95724 & 69.7 & 824 & 0.9 \\
\hline 4530788.3 & S1500_2 & \multirow{4}{*}{$\begin{array}{l}\text { Mata de } \\
\text { galeria }\end{array}$} & 124049 & 109897 & 88.6 & $506+-228$ & 74067 & 67.4 & 590 & 0.8 \\
\hline 4530789.3 & S1500_3 & & 111995 & 99193 & 88.6 & $497+-228$ & 68485 & 69.0 & 616 & 0.9 \\
\hline 4530790.3 & S2500_1 & & 93793 & 87153 & 92.9 & $533+-235$ & 60647 & 69.6 & 553 & 0.9 \\
\hline 4530791.3 & S2500_2 & & 110995 & 102792 & 92.6 & $516+-235$ & 67936 & 66.1 & 540 & 0.8 \\
\hline 4530792.3 & S2500_3 & \multirow[t]{2}{*}{ Campo limpo } & 117700 & 109072 & 92.7 & $518+-233$ & 71091 & 65.2 & 541 & 0.8 \\
\hline 4530793.3 & S4500_1 & & 134824 & 125346 & 93.0 & $530+-232$ & 89215 & 71.2 & 775 & 0.9 \\
\hline 4530794.3 & S4500_2 & \multirow{3}{*}{$\begin{array}{l}\text { Cerrado sensu } \\
\text { stricto }\end{array}$} & 109725 & 101547 & 92.5 & $528+-233$ & 69763 & 68.7 & 611 & 0.9 \\
\hline 4530795.3 & S4500_3 & & 92711 & 85968 & 92.7 & $516+-230$ & 60202 & 70.0 & 468 & 0.8 \\
\hline 4549601.3 & $3-1$ & & 29,300 & 26,477 & 90.4 & $369 \pm 197$ & 13490 & 50.9 & 125 & 0.9 \\
\hline 4549602.3 & $3-2$ & \multirow{4}{*}{$\begin{array}{l}\text { Mata de } \\
\text { galeria }\end{array}$} & 97323 & 87,225 & 89.6 & $367 \pm 198$ & 42619 & 48.9 & 427 & 1.0 \\
\hline 4549603.3 & $3-3$ & & 158,046 & 143,133 & 90.6 & $405 \pm 206$ & 75947 & 53.1 & 741 & 1.0 \\
\hline 4549604.3 & $5-1$ & & 90,820 & 81,438 & 89.7 & $363 \pm 195$ & 40957 & 50.3 & 361 & 0.9 \\
\hline 4549605.3 & $5-2$ & & 70,945 & 64,366 & 90.7 & $394 \pm 204$ & 33387 & 51.9 & 295 & 0.9 \\
\hline 4549606.3 & $5-3$ & \multirow[t]{2}{*}{ Campo sujo } & 138,667 & 124,865 & 90.0 & $382 \pm 202$ & 64187 & 51.4 & 548 & 0.9 \\
\hline 4549607.3 & $6-1$ & & 61,706 & 55,778 & 90.4 & $401 \pm 206$ & 29867 & 53.5 & 258 & 0.9 \\
\hline 4549608.3 & $6-2$ & \multirow{3}{*}{$\begin{array}{l}\text { Floresta semi- } \\
\text { decídua }\end{array}$} & 58,538 & 52,355 & 89.4 & $377 \pm 200$ & 26786 & 51.2 & 285 & 1.1 \\
\hline 4549609.3 & $6-3$ & & 55,249 & 49,503 & 89.6 & $390 \pm 202$ & 26254 & 53.0 & 254 & 1.0 \\
\hline 4549610.3 & $7-1$ & & 68,945 & 61,970 & 89.9 & $384 \pm 204$ & 31671 & 51.1 & 281 & 0.9 \\
\hline 4549611.3 & $7-2$ & \multirow{2}{*}{$\begin{array}{l}\text { Cerrado sensu } \\
\text { stricto }\end{array}$} & 84,655 & 76,224 & 90.0 & $392 \pm 205$ & 40552 & 53.2 & 418 & 1.0 \\
\hline 4549612.3 & $7-3$ & & 78,491 & 70,321 & 89.6 & $371 \pm 198$ & 36068 & 51.3 & 352 & 1.0 \\
\hline
\end{tabular}




\title{
Chapter 3 - Short-term impact of soybean management on ammonia oxidizers in a
} Brazilian savanna under restoration as revealed by coupling different techniques ${ }^{3}$

"Nem tudo o que é torto é errado: veja as pernas do Garrincha, veja as árvores do Cerrado"

Nicolas Behr

\begin{abstract}
Interactions between soil characteristics and soil microbiota influence soil ecosystem processes such as nitrification however, their complexity makes interpretation difficult. Furthermore, the impact of soil management systems on abundance and activity of soil microbial community is poorly understood, especially in the Neotropics. To investigate these interactions, the effects of tillage, inorganic fertilization, and plant cover on the abundance of ammonia-oxidizing archaea (AOA) and ammonia-oxidizing bacteria (AOB) were assessed by quantification of the marker gene $(a m o A)$ during different stages of soybean cultivation in a site under restoration from gravel extraction in the Central Brazilian Savanna (Cerrado). Results of molecular analysis and classic and isotope techniques showed that levels of organic $\mathrm{C}$ and $\mathrm{NH}_{4}{ }^{+}-\mathrm{N}$ were higher in the soybean field during fallow than in an adjacent undisturbed field (Campo sujo). Ammonia oxidizer abundance and nitrification rates were also higher in the agricultural soil than in the undisturbed site, with the lowest ammonium/nitrate ratio in tilled soil. Soil $\delta^{15} \mathrm{~N}$ was lower in the undisturbed soil than the agricultural soil. Both $A O A$ and $A O B$ were more abundant during soybean crop transitional stages, and this increase positively correlated with soil $\mathrm{pH}$, particularly for $\mathrm{AOB}$ abundance, in tilled soil and within the soybean rhizosphere. The results suggest that $A O B$ have more copiotrophic characteristics than AOA and are better able to change available ammonium in the soil. The combination of standard soil ecological methods and modern molecular analysis show the short-term modification of ammonia oxidizer abundance and soil $\mathrm{N}$ dynamics in a managed system within the Cerrado biome.
\end{abstract}

\footnotetext{
${ }_{3}^{3}$ Catão, E. C. P.; Lopes, F. A. C.; Rubini, M. R.; Nardoto, G. B.; Prosser, J. I.; Krüger, R. H. (2016) Shortterm impact of soybean management on ammonia oxidizers in a Brazilian savanna under restoration as revealed by coupling different techniques. Biology and Fertility of Soils, 1-12. DOI 10.1007/s00374015-1086-0
} 


\section{Introduction}

The impact of land use on the functioning of soil microbiota has consequences for the processes governed by these organisms and consequently for the terrestrial ecological services that they provide (e.g., decomposition and nutrient cycling). Agriculture and managed pasture for cattle breeding have converted approximately 53\% (117,870 $\left.\mathrm{km}^{2}\right)$ of the Cerrado biome landscape in the last two decades (Beuchle et al., 2015), with increasing alterations in floristic composition and edaphic characteristics due to fertilization, liming, and crop monoculture itself. Changes in soil use and management likely modify the $\mathrm{C}$ and $\mathrm{N}$ dynamics in these areas, leading to changes in soil $\mathrm{C}$ and $\mathrm{N}$ stocks and increases in greenhouse gas emissions to the atmosphere (Carvalho et al., 2009).

Soil management and monoculture crops are associated with a decrease in total and microbial N, particularly in conventional tillage systems (Hernández-Hernández and López-Hernández, 2002). In contrast, no-till management is associated with better soil quality and higher enzyme activity (Peixoto et al., 2010) and microbial C biomass (VinhalFreitas et al., 2012). In addition, no-till farming appears to have fewer effects on the composition of microbial communities (Rachid et al., 2013). Previous research has shown that the soybean plant influences the composition of the soil microbial community, with lower microbial diversity observed during plant development in soils under soybean cultivation (Bresolin et al., 2010).

In the Amazonian forest, land use change alters functional gene diversity and the composition and abundance of soil microbial communities, with differences in soil pH and organic matter content linked to differences in the composition of genes, including those associated with C and N cycles (Paula et al., 2014). For example, $15 \%$ to $30 \%$ of genes related to the $\mathrm{N}$ cycle have their abundances affected by the cultivation of bioenergy crops (Zea mays and Miscanthus giganteus) (Mao et al., 2011), indicating that agriculture has an impact not only on microbial taxonomic composition but also on its potential ecological functions.

In view of the economic and ecological costs of fertilization and $\mathrm{N}$ losses, it is important to investigate nitrifiers in Cerrado soils to develop better soil management practices. Undisturbed Cerrado soils under native vegetation have low pH and a high $\mathrm{NH}_{4}{ }^{+}-$ $\mathrm{N}: \mathrm{NO}_{3}-\mathrm{N}$ ratio but very low nitrification rates (Nardoto and Bustamante, 2003) and insignificant $\mathrm{N}_{2} \mathrm{O}$ emissions (Cruvinel et al., 2011; Pinto et al., 2006; Pinto et al., 2002). These characteristics are often associated with a greater abundance of ammonia-oxidizing archaea (AOA) (Gubry-Rangin et al., 2011; Gubry-Rangin et al., 2010; Nicol et al., 2008), which 
appear to prefer ammonia generated from the mineralization of organic $\mathrm{N}$ and are the predominant ammonia oxidizers in acid soils (Levičnik-Höfferle et al., 2012; Prosser and Nicol, 2012; Zhang et al., 2012). In contrast, ammonia-oxidizing bacteria (AOB) are more commonly associated with nitrification in soils with higher ammonia input (Jia and Conrad, 2009); therefore, the addition of inorganic or organic $N$ fertilizers may influence the relative abundance of $A O A$ and $A O B$. The abundance of ammonia oxidizers, which perform the ratelimiting step of nitrification, can be estimated by amplification of the amoA gene, which encodes subunit $\mathrm{A}$ of ammonia monooxygenase.

Investigation of nitrification in the Cerrado biome is of particular interest because this ecosystem is N-limited (Bustamante et al., 2012b), with low nitrate content (Bustamante et al., 2006; Nardoto and Bustamante, 2003) and low rates of nitrification (Bustamante et al., 2006; Nardoto and Bustamante, 2003). These characteristics are usually associated with a high litter level and soil C: $\mathrm{N}$ ratio, leading to low availability of $\mathrm{N}$ and a higher rate of $\mathrm{N}$ immobilization than mineralization (Bustamante et al., 2006; Nardoto and Bustamante, 2003).

Long-term land use is believed to modify the composition of soil microbial communities (Jangid et al., 2011; Paula et al., 2014), but few studies have described the short-term impacts (Lazcano et al., 2013). This study investigated the short-term effects of land use change, over 134 days, on ammonia oxidizers and tested the following hypotheses: (1) AOA are more abundant than $A O B$ in undisturbed Campo sujo soil and in soybean site during the fallow period because of lower $\mathrm{pH}$ and provision of ammonium mainly by net $\mathrm{N}$ mineralization; (2) the relative abundance of $A O B$ is greater in agricultural fertilized soil; and (3) the relative abundance of $A O B$ increases during crop establishment due to the increase in $\mathrm{pH}$ and addition of inorganic fertilizers, which are associated with an increase in nitrate content and nitrification. To test these hypotheses, changes in archaeal and bacterial amoA gene abundance were determined by GPCR analysis in a soybean field and in soil from an adjacent undisturbed site (Campo sujo). This work describes short-term changes in the abundance of ammonia oxidizers in soil being restored after decades of gravel extraction in the Cerrado biome by evaluating the impact of soil management on microbial communities. 


\section{Materials and methods}

\section{Study sites and soil characteristics}

The field sites are located in the Cerrado biome within a commercial farm, Fazenda Tabapuã dos Pireneus, in the municipality of Cocalzinho de Goiás (Federal State of Goiás, Brazil). Average precipitation and temperature during sampling (134 days between the first and last days of sampling, October 13, 2012 and March 24, 2013, respectively), measured at the nearest meteorological center (approximately $30 \mathrm{~km}$ from the farm; Pirenopolis, GO, Station $83376,15^{\circ} 50^{\prime} 60^{\prime \prime S} 48^{\circ} 57^{\prime} 36^{\prime \prime} \mathrm{W}$ ), were $270 \mathrm{~mm}$ per month (Figure 9) and $24.8^{\circ} \mathrm{C}$ (range $19^{\circ} \mathrm{C}-32.5^{\circ} \mathrm{C}$ ). The climate in the Cerrado biome is tropical (Köppen Aw), and all soil samples were collected during the wet season (October to April), when $90 \%$ of the annual precipitation occurs.
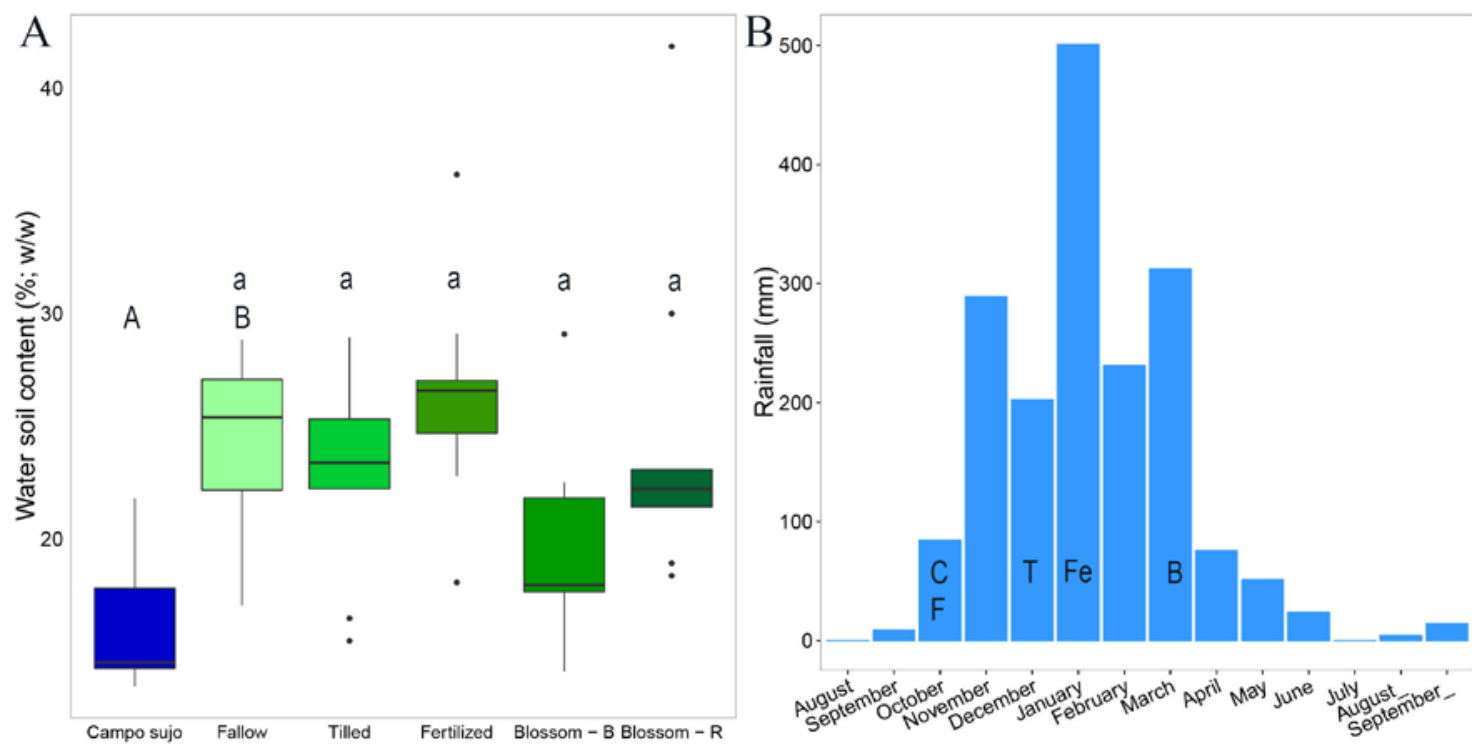

Figure 10. Gravimetric soil water content. Boxplot created by R version 3.0.2 with the ggplot2 library. Letters and corresponding colors correspond to significant differences among groups after the Tukey-Kramer post hoc test. In (B) letters represent when soils were sampled, $C$ Campo sujo, $F$ Fallow, $T$ Tilled, Fe Fertilization, B Blossom.

This study focused on two sites: an undisturbed site dominated by grass and dispersed shrubs, known as Campo sujo (Ribeiro 2008) (15 46 $01^{\prime \prime} \mathrm{S}, 48^{\circ} 48^{\prime} 57^{\prime \prime} \mathrm{W}$ ) and an adjacent site (approximately $200 \mathrm{~m}$ away) converted to soybean crop (15\%46'06"S, $48^{\circ} 48^{\prime} 55^{\prime \prime} \mathrm{W}$ ) (hereafter called the "soybean site"). Both sites have the same average altitude $(1,118 \mathrm{~m})$, rainfall, and air temperature. The soybean site, which was degraded because of gravel removal activity that occurred over decades, is in the process of restoration to become an integrated livestock-forest system. It was first cultivated in 2012, 
with the establishment of maize followed by natural fallow. For maize cultivation a solution of $100 \mathrm{~kg} \mathrm{ha}^{-1}$ of NPK (8:30:16) and $200 \mathrm{~kg} \mathrm{ha}^{-1}$ urea were applied to the soil after plowing. Soybean seeds were then sowed after a 1-year fallow period. For soybean cultivation, an NPK mixture (8:30:16) and 8\% micronutrient mixture (FPE BR12) were added to the soil at 5 $\mathrm{cm}$ depth. The transgenic soybean Glycine max Bayer variety 810 was sowed (after inoculation with rhizobia) every $10 \mathrm{~cm}$ in rows separated by $50 \mathrm{~cm}$. Soil from the soybean site was sampled four times: after 9 months of natural fallow since the last maize cultivation (F; mid-October 2013); the day after the soil was tilled to a depth of $20 \mathrm{~cm}$ (T; first week of December 2012); 1 month after fertilization (FE, first week of January 2013); and at the blossom soybean stage of development (end of February 2013), at which time bulk soil (B) and rhizosphere soil (soil in direct contact with the root) (Rz) were sampled. To obtain soil from the rhizosphere, plants near the bulk soil sampling location were removed, the soil loosely surrounding the plant was released, and adherent soil at the rhizosphere was collected mechanically in a plastic bag. Figure 10 illustrates the treatments and the two study sites. Although crops in this farm are usually cultivated using no-till management, the history of gravel extraction in the soybean site necessitated use of a plow in deeper soil (20 $\mathrm{cm}$ ). The farmer did not initially consider plowing, and only the top $10 \mathrm{~cm}$ (more active layer) was sampled.

Soil was obtained at nine locations at the two adjacent sites. The nine replicates were used for $\mathrm{N}$ concentration, $\mathrm{pH}$, and soil water content measurements. However, for the remaining physicochemical data, molecular, and $\delta^{15} \mathrm{~N}$ analysis, the samples were combined into triplicate samples, according to the column numbers presented in Figure 10. In the soybean site, samples were taken from the rows. At each location, 10 soil core samples (10 cm deep, $5 \mathrm{~cm}$ diameter) (Figure 10) were obtained, passed through a 2-mm mesh sieve, combined, and then stored at $-20^{\circ} \mathrm{C}$ for subsequent physicochemical and molecular analyses. Inorganic $\mathrm{N}$ was extracted by agitating the soil sample for $1 \mathrm{~h}$ in $1 \mathrm{M} \mathrm{KCl}$ (1:5 soil/solution ratio). $\mathrm{NH}_{4}{ }^{+}-\mathrm{N}$ was determined using the Nessler colorimetric method (Embrapa 1999) with a spectrophotometer set at $425 \mathrm{~nm}$. $\mathrm{NO}_{3}^{-}-\mathrm{N}$ was determined by spectrophotometry (Mulvaney 1996) at $218 \mathrm{~nm}$, subtracting interference caused by organic matter at 254 and $280 \mathrm{~nm}$ (Meier 1991). These measurements were considered time zero and compared with $\mathrm{NH}_{4}{ }^{+} \mathrm{N}$ and $\mathrm{NO}_{3}{ }^{-} \mathrm{N}$ measurements after samples were incubated in the laboratory in separate closed plastic bags for 7 days at room temperature in the dark (Piccolo et al. 1994). Net $\mathrm{N}$ mineralization and nitrification rates were expressed as changes 
in $\mathrm{NH}_{4}{ }^{+}-\mathrm{N}+\mathrm{NO}_{3}^{-}-\mathrm{N}$ or $\mathrm{NO}_{3}^{-}-\mathrm{N}$, respectively, during the 7 days of incubation. All results are expressed in per g oven-dried $\left(105^{\circ} \mathrm{C}\right)$ soil.

A

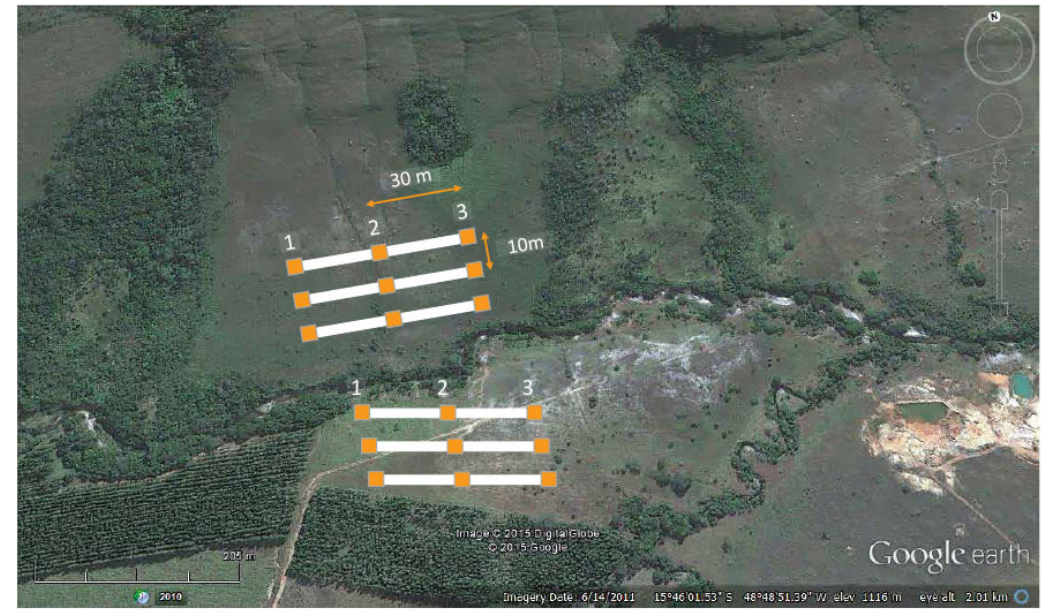

B

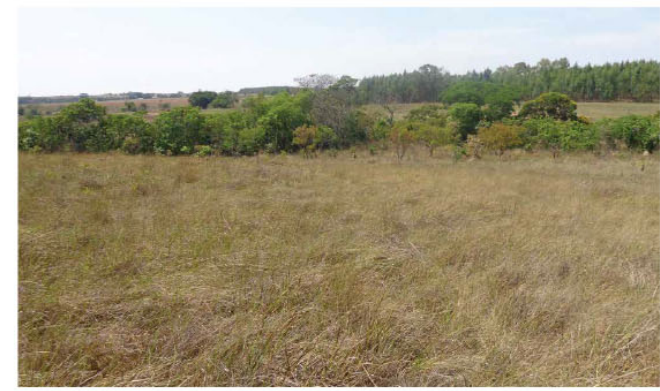

D

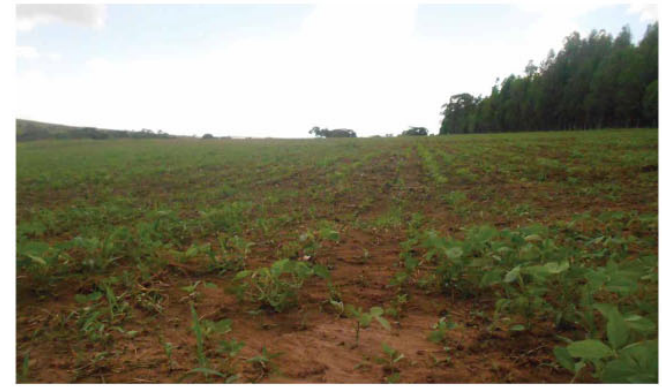

C

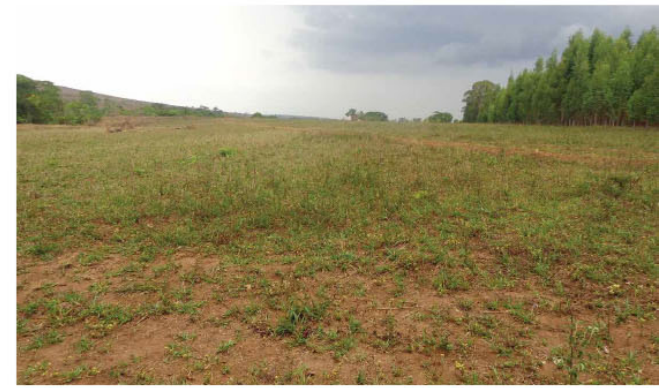

$\mathrm{E}$

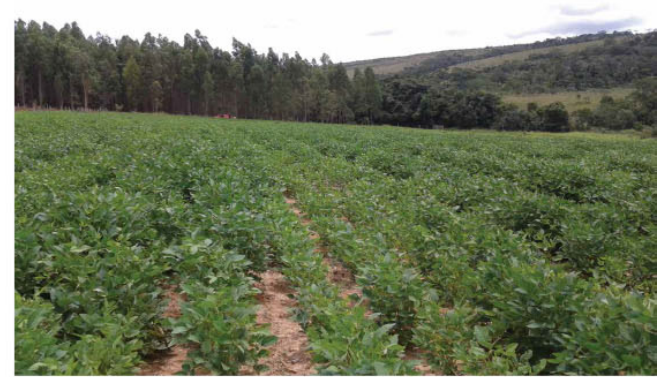

$\mathrm{F}$

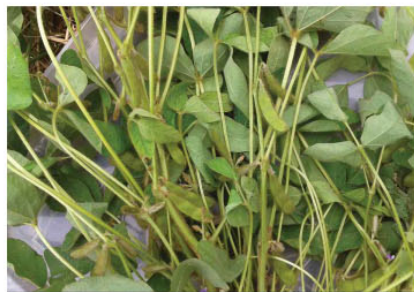

Figure 11. Satellite view and photographs of the sample site on the Tabapuã dos Pireneus Farm. (A) Schematic representation of the sampling design on a Google Earth picture from the sample site. 1-3 represent composite samples for molecular analysis. (B)-(F) Photos of 
the soil collection sites. (B) Undisturbed Campo sujo site, (C)-(F) Soybean site at four different time points: (C) after 9 months of natural fallow, (D) 1 month after fertilization, (E) during the blossom stage of soybean development, (F) soybean plants with beans.

Physicochemical and molecular analyses were performed in biological triplicates. Soil texture and concentrations of macro- and micronutrients were determined by using standard methods (Soils Embrapa-SNLCS) at SoloQuímica, Inc, Brasília, Brazil. Both soils are well-aerated and well-drained. The undisturbed Campo sujo soil is classified as sandy loam with $20.8 \%$ clay, and the soybean site is a sandy clay soil with $31.7 \%$ clay. Both soils are considered to have a medium clay texture (Embrapa 2006) (Table 1). This work is not meant to compare the sites but to describe the rapid change in ammonia oxidizer abundance during the establishment of a soybean crop. The undisturbed site was used as a control to represent nitrification in a pristine Cerrado area.

Table 5. Soil physicochemical properties for each one of the replicates in all treatments

\begin{tabular}{|c|c|c|c|c|c|c|c|c|c|c|}
\hline & \multicolumn{2}{|c|}{ Campo sujo } & \multicolumn{2}{|c|}{ Fallow } & \multicolumn{2}{|c|}{ Tilled } & \multicolumn{2}{|c|}{ Fertilized } & \multicolumn{2}{|c|}{ Bulk - Blossom } \\
\hline $\mathrm{SWC}\left(\% \mathrm{H}_{2} \mathrm{O} \mathrm{g}^{-1} \mathrm{DS}\right)$ & 16.1 & \pm 0.9 & 21.7 & \pm 2.063 & 22.9 & \pm 1.873 & 26.3 & \pm 1.583 & 19.8 & \pm 1.675 \\
\hline Clay $\left(\mathrm{g} \mathrm{kg}^{-1}\right)$ & 208.3 & \pm 8.3 & 308.3 & \pm 8.333 & 325.0 & \pm 14.434 & 333.3 & \pm 8.333 & 300.0 & \pm 14.434 \\
\hline Sand $\left(\mathrm{g} \mathrm{kg}^{-1}\right)$ & 733.3 & \pm 8.3 & 600.0 & \pm 14.434 & 541.7 & \pm 8.333 & 550.0 & \pm 14.434 & 558.3 & \pm 16.667 \\
\hline Silt $\left(g_{\text {kg-1}}\right)$ & 58.3 & \pm 8.3 & 91.7 & \pm 8.333 & 133.3 & \pm 16.667 & 116.7 & \pm 8.333 & 141.7 & \pm 8.333 \\
\hline $\mathrm{pH}\left(\right.$ in $\left.\mathrm{H}_{2} \mathrm{O}\right)$ & 5.4 & \pm 0.1 & 5.5 & \pm 0.058 & 6.0 & \pm 0.033 & 6.0 & \pm 0.033 & 6.0 & \pm 0.058 \\
\hline $\mathrm{pH}($ in $\mathrm{KCl})$ & 3.6 & \pm 0.1 & $4 \cdot 3$ & \pm 0.100 & 5.2 & \pm 0.033 & 5.2 & \pm 0.058 & 5.0 & \pm 0.058 \\
\hline CEC (cmolc dm³) & 6.0 & \pm 0.6 & 6.0 & \pm 0.577 & 6.3 & \pm 0.333 & 6.7 & \pm 0.333 & 6.7 & \pm 0.333 \\
\hline $\mathrm{Al}\left(\mathrm{cmolc} \mathrm{dm}^{-3}\right)$ & 1.2 & \pm 0.1 & 0.1 & \pm 0.033 & 0.0 & \pm 0.000 & 0.0 & \pm 0.000 & 0.0 & \pm 0.000 \\
\hline $\mathrm{N}(\%)$ & 0.11 & \pm 0.00 & 0.12 & \pm 0.01 & 0.12 & \pm 0.01 & 0.12 & \pm 0.00 & 0.10 & \pm 0.00 \\
\hline$\delta^{15} \mathrm{~N}$ & 5.64 & \pm 0.08 & 7.05 & \pm 0.12 & 7.15 & \pm 0.16 & 7.16 & \pm 0.10 & 7.57 & ד. \\
\hline$C(\%)$ & 1.76 & \pm 0.03 & 2.04 & \pm 0.16 & 1.99 & \pm 0.12 & 1.92 & \pm 0.10 & 1.63 & \pm 0.06 \\
\hline $\mathrm{OM}\left(\mathrm{g} \mathrm{kg}^{-1}\right)$ & 42.6 & \pm 2.4 & 45.0 & \pm 4.159 & 39.1 & \pm 1.258 & 38.1 & \pm 2.118 & 36.5 & \pm 2.586 \\
\hline$P\left(\mathrm{mg} \mathrm{dm}^{-3}\right)$ & 8 & \pm 0.1 & 1.2 & \pm 0.418 & 14.6 & \pm 6.053 & 14.1 & \pm 1.510 & 20.9 & \pm 11.767 \\
\hline $\mathrm{Ca}(\mathrm{cmol}$ & 0.4 & \pm 0.06 & 0.7 & \pm 0.115 & 2.7 & \pm 0.067 & 2.7 & \pm 0.338 & 2.7 & \pm 0.088 \\
\hline $\mathrm{Mg}\left(\mathrm{cmolc} \mathrm{dm}^{-3}\right)$ & 0.1 & \pm 0.03 & 0.6 & \pm 0.145 & 0.8 & \pm 0.033 & 0.7 & \pm 0.120 & 0.8 & \pm 0.033 \\
\hline $\mathrm{B}\left(\mathrm{mg} \mathrm{dm^{-3 }}\right)$ & 0.24 & \pm 0.04 & 0.10 & \pm 0.039 & 0.46 & \pm 0.012 & 0.49 & \pm 0.040 & 0.48 & \pm 0.026 \\
\hline $\mathrm{Cu}\left(\mathrm{mg} \mathrm{dm} \mathrm{m}^{-3}\right)$ & 1.72 & \pm 0.04 & 1.57 & \pm 0.113 & 0.06 & \pm 0.020 & 0.05 & \pm 0.012 & 0.05 & \pm 0.028 \\
\hline $\mathrm{Fe}\left(\mathrm{mg} \mathrm{dm}^{-3}\right)$ & 165.40 & \pm 41.01 & 86.03 & \pm 6.731 & 106.40 & \pm 4.277 & 141.00 & \pm 7.000 & 92.37 & \pm 29.453 \\
\hline $\operatorname{Mn}\left(\mathrm{mg} \mathrm{dm} \mathrm{m}^{-3}\right)$ & 68.74 & \pm 58.82 & 9.01 & \pm 2.865 & 7.70 & \pm 0.141 & 7.43 & \pm 1.017 & 8.64 & \pm 0.380 \\
\hline $\mathrm{Zn}\left(\mathrm{mg} \mathrm{dm} \mathrm{dm}^{-3}\right)$ & 1.75 & \pm 1.71 & 0.22 & \pm 0.101 & 1.65 & \pm 0.405 & 2.34 & \pm 0.418 & 3.54 & \pm 1.033 \\
\hline $\mathrm{S}\left(\mathrm{mg} \mathrm{dm}^{-3}\right)$ & 6.03 & \pm 0.15 & 3.20 & \pm 0.100 & 3.13 & \pm 0.145 & 4.13 & \pm 0.865 & 4.63 & \pm 0.835 \\
\hline
\end{tabular}

AT: average temperature; SWC: Soil water content; CEC: cation exchange capacity; DS: dry soil; OM: organic matter. 
Isotope analysis

All soil samples were air-dried and ground to a fine powder. A sub-sample of 15 to $20 \mathrm{mg}$ was sealed in a tin capsule and loaded into a ThermoQuest-Finnigan Delta Plus isotope ratio mass spectrometer (Finnigan-MAT; CA, USA) coupled with an elemental analyzer (Carlo Erba model 1110; Milan, Italy). These analyses were performed at Centro de Energia Nuclear na Agricultura (CENA - USP) in Piracicaba, Brazil. The natural abundance of stable isotopes of $\mathrm{C}$ and $\mathrm{N}$ were measured in relation to recognized international standards. As standard laboratory procedure, internal working standards (atropine and soil standard no. 502-308 from LECO Corporation) were included in every run. Relative stable isotope values are reported in "delta" notation, as $\delta$ values in parts per thousand (\%) according to the molar ratio $(R)$ of the rare to abundant isotope $\left({ }^{15} \mathrm{~N} /{ }^{14} \mathrm{~N} ;{ }^{13} \mathrm{C} /{ }^{12} \mathrm{C}\right)$, i.e. $\delta \%=(R$ sample $/ R$ standard -1$) \times$ 1,000 . The precision of measurements was \pm 0.3 and $0.5 \%$ for $\delta^{13} \mathrm{C}$ and $\delta^{15} \mathrm{~N}$, respectively.

\section{DNA extraction}

DNA was extracted from $0.5 \mathrm{~g}$ soil using the FastDNA Spin Kit (MP Biomedicals) with additional treatment using solutions 2 and 3 from the PowerSoil DNA Isolation Kit (MO Bio Laboratories Inc.) to achieve maximum DNA yields with the least organic contamination. The DNA was analyzed by $1 \%(\mathrm{w} / \mathrm{v})$ agarose gel electrophoresis. The average concentration

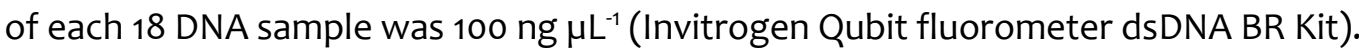

\section{Real-time PCR}

Thaumarchaeota 16S rRNA and archaeal and bacterial amoA genes were amplified in an

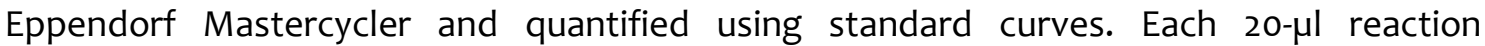
contained 1X QuantiFast master mix (for $A O A$ ) or QuantiTect master mix (for $A O B$ ) (Qiagen), $0.4 \mu \mathrm{M}$ primers (archaeal $16 \mathrm{~S} \mathrm{rRNA}, \mathrm{AOA}$ amoA) or $0.6 \mu \mathrm{M}$ primers (AOB amoA), 2 $\mu g \mu^{-1}$ bovine serum albumin (Promega), and $5 \mathrm{ng}$ DNA. The thaumarchaeal $16 \mathrm{~S}$ rRNA gene was amplified with the $771 \mathrm{f}$ and $958 \mathrm{r}$ primers (Ochsenreiter et al. 2003), the AOA amoA gene with the crenamo23f and crenamo616r primers (Tourna 2008), and the AOB amoA gene with the amoA1F and amoA2R primers (Rotthauwe et al. 1997). Cycling conditions were as follows: $15 \mathrm{~min}$ at $95^{\circ} \mathrm{C}$ followed by 40 cycles of $15 \mathrm{~s}$ at $94^{\circ} \mathrm{C}$ and $1 \min 30 \mathrm{~s}$ at $60^{\circ} \mathrm{C}$ for the AOA amoA gene; and $15 \mathrm{~min}$ at $95^{\circ} \mathrm{C}$ followed by $45 \mathrm{cycles}$ of $1 \mathrm{~min}$ at $94^{\circ} \mathrm{C}, 1 \mathrm{~min}$ at $55^{\circ} \mathrm{C}$, and $1 \mathrm{~min}$ at $72^{\circ} \mathrm{C}$ for the $\mathrm{AOB}$ amoA gene. Fluorescence was measured after $5 \mathrm{~s}$ at 
$80^{\circ} \mathrm{C}(\mathrm{AOA} a m o A)$ or $8 \mathrm{~s}$ at $83^{\circ} \mathrm{C}(\mathrm{AOB} a m o A)$ to exclude fluorescence contamination of potential primer-dimers. Melting curves between $65^{\circ} \mathrm{C}$ and $95^{\circ} \mathrm{C}$ were analyzed for each run.

Standards were made from 10-fold dilutions of the fragment of the gene of interest. This fragment was obtained by amplification of the genes with the respective primers from a composite of the soil samples used in this work. The fragment was cloned into a PGEM®-T Easy Vector (Promega) and re-amplified using M13 primers that recognize sites flanking the cloned fragment. Three clones of each gene were selected and verified by Sanger sequencing. The longer and more accurate sequence was chosen as the standard. Plasmid DNA concentrations were verified using a Qubit 2.0 fluorometer (Life Technologies) and NanoDrop 1000 spectrophotometer (Thermo Scientific). To verify the correct size of individual PCR products, melting curve and agarose gel electrophoresis analyses were performed. To exclude the fluorescence from potential primer-dimers, fluorescence was captured after each amplification cycle above $80^{\circ} \mathrm{C}$. Efficiency of amplification and $r^{2}$ values were 0.86 and 0.990 for archaeal 16S rRNA, 0.92 and 0.995 for archaeal $a m o A$, and 0.86 and 0.994 for bacterial amoA, respectively. No inhibition was detected in assays consisting of soil DNA diluted in water or with a known amount of standard DNA.

\section{Statistical Analysis}

Statistical analyses were performed in R (v 3.0.2), and all qPCR and physicochemical data were analyzed for normality and homoscedasticity with both Kolmogorov-Smirnov and Levene's test statistics. Data that did not follow a normal distribution were logtransformed. One-way ANOVA tests were used to make multiple comparisons, with TukeyKramer post hoc tests to compare the group means shown in the graphs with different letters and corresponding colors. All graphs in the boxplot format were prepared in R with the ggplot2 library, in which the default is to present the upper and lower sides of the box as the first and third quartile, whiskers corresponding to the highest and lowest values within 1.5 interquartile range (IQR), and dots representing outliers outside the IQR. The Pearson correlation was used to evaluate relationships between GPCR data and physicochemical variables with relevant biological implications (i.e., $\mathrm{pH}$, net nitrification rate, $\delta^{15} \mathrm{~N}$ ). The Bonferroni (Rice 1989) or Benjamini-Hochberg (BH) (Benjamini and Hochberg 1995) methods were used to correct $p$ values for multiple comparisons; the Bonferroni correction is more conservative. 


\section{Results}

Description of study sites and soil physicochemical characteristics

Water content of the undisturbed soil was lower than that of the soybean site at all time points, including soil collected on the same day in the soybean site during fallow. This finding may reflect differences in soil texture (Figure 9). Fallow soil from the soybean site contained residual material from the previous maize cultivation. Before sowing, 2 ton ha-1 limestone was applied to the soil, which increased soil $\mathrm{pH}$ in $\mathrm{H}_{2} \mathrm{O}$ from 5.5 (4.3 in $\mathrm{KCl}$ ) to 6 ( 5.2 in $\mathrm{KCl}$ ). The undisturbed Campo sujo soil had lower $\mathrm{pH}$ values $\left(5.4\right.$ in $\mathrm{H}_{2} \mathrm{O}$ and 3.6 in $\mathrm{KCl}$ ) (Table 1).

Principal component analysis of soil physicochemical data (Figure 1) indicated that the physicochemical characteristics in the fallow soil differed significantly from soil collected in the soybean site at the other time points (Figure 11A). The undisturbed soil also differed from the fallow soil from the soybean site, which had higher organic $\mathrm{C}$ and $\mathrm{NH}_{4}{ }^{+} \mathrm{N}$ concentrations (Figure 11B). However, other soils obtained from the soybean site clustered together, indicating similar physicochemical characteristics. In particular, these soils had higher $\mathrm{pH}$ and levels of nitrate, water, and micronutrients compared to the undisturbed Campo sujo soil and fallow soil (Figure 11B). 

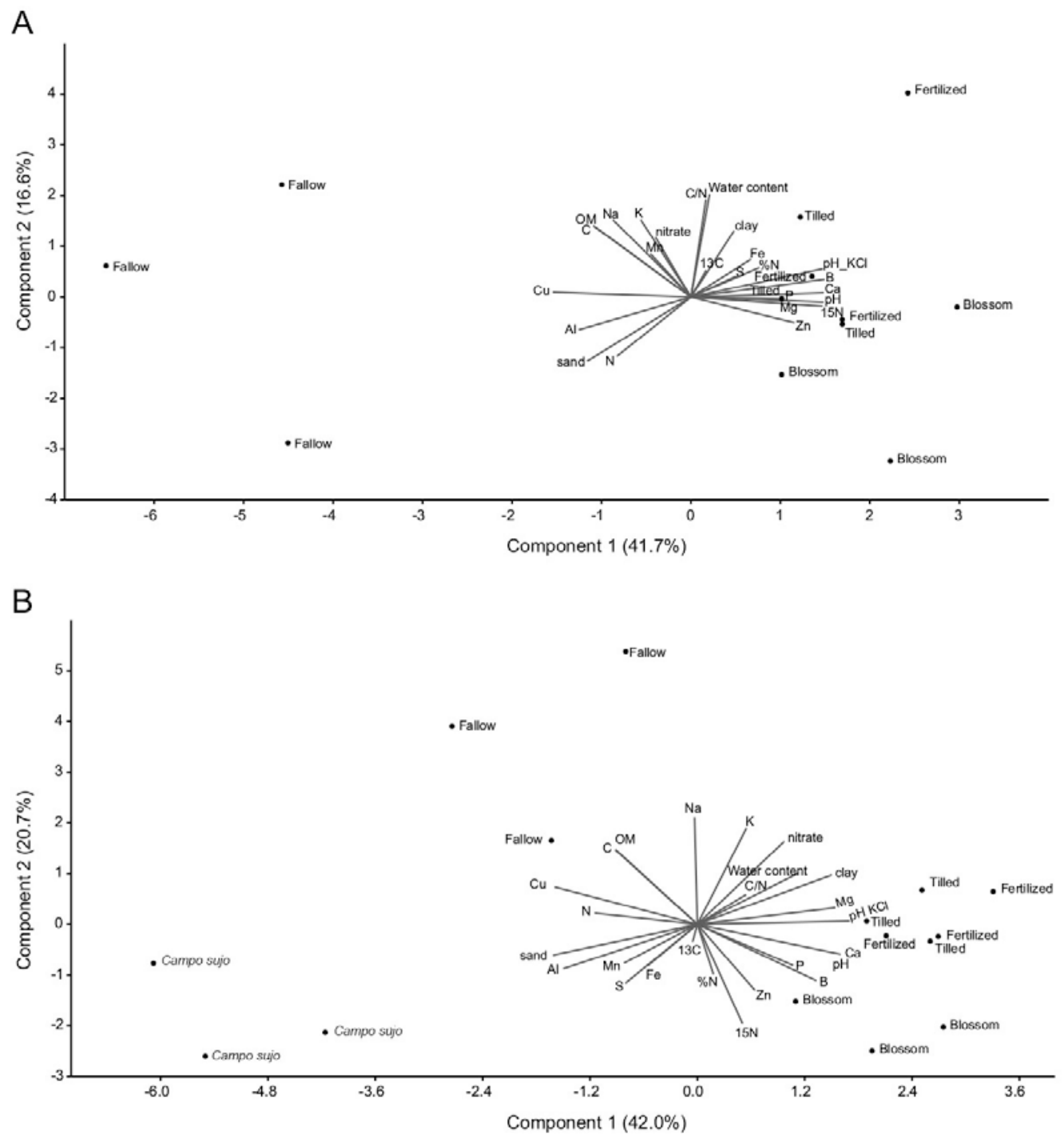

Figure 12. Principal component analysis (PCA) of soil physicochemical properties based on a correlation matrix performed in PAST v.3.01 (Hammer et al., 2001). (A) Analysis of soybean site samples; (B) all samples including soil from the undisturbed Campo sujo site. Each vector points in the direction in which the respective value increases.

Ammonium and nitrate concentrations and soil $\delta^{15} \mathrm{~N}$

$\mathrm{NH}_{4}{ }^{+}-\mathrm{N}$ concentration in the undisturbed Campo sujo soil generally ranged from 5 to $8.3 \mu \mathrm{g}$ $\mathrm{g}^{-1}$ dry soil, with two outliers of 11.8 and $48.7 \mu \mathrm{g} \mathrm{g}^{-1}$ dry soil (Figure $12 \mathrm{~A}$ ). The potential net $\mathrm{N}$ mineralization rate, determined by incubation of soil in the laboratory at room temperature, indicated that $\mathrm{NH}_{4}{ }^{+}-\mathrm{N}$ was becoming available in these soils at a rate of 0.8 to $3.29 \mathrm{NH}_{4}{ }^{+}-\mathrm{N} \mathrm{\mu g} \mathrm{g}^{-1}$ dry soil day ${ }^{-1}$ (Figure $12 \mathrm{C}$ ).

$\mathrm{NH}_{4}{ }^{+}-\mathrm{N}$ concentration was higher than $\mathrm{NO}_{3}{ }^{-} \mathrm{N}$ concentration in every soil sample but was particularly high in the undisturbed Campo sujo soil (Figure 12E). Fallow, tilled, and fertilized soils of the soybean site had similar average $\mathrm{NO}_{3}{ }^{-} \mathrm{N}$ concentrations, which were 
higher than that of the bulk soil and rhizosphere soil collected during the blossom stage (Figure 12B). Nitrification was greater in fallow soil from the soybean site than in undisturbed Campo sujo soil (Figure 12D). Analysis of the soybean site samples showed a decrease in $\mathrm{NH}_{4}^{+}-\mathrm{N}$ concentration as the crop developed, with significantly lower concentration in tilled soil and soil collected during the blossom stage of soybean development (both bulk and rhizosphere soils) than in fallow soil (Figure 12A). Nitrogen immobilization was greater than mineralization in fallow soil, recently tilled soil, bulk soil during the blossom stage, and especially in soil collected 1 month after fertilization. Nonetheless, the average net $\mathrm{N}$ mineralization differed significantly only between fertilized soil and soil collected during the blossom stage (both bulk and rhizosphere soils) (Figure 12C). Because fertilization was carried out at the same time as sowing, plant growth may have influenced the results obtained from soil collected 1 month after fertilization through $\mathrm{NH}_{4}{ }^{+} \mathrm{N}$ uptake and the low inorganic $\mathrm{N}$ content in soil collected during the blossom stage. However, net $\mathrm{N}$ mineralization and nitrification occurred in a plant-free soil bag under laboratory conditions; therefore, $\mathrm{NH}_{4}{ }^{+}$would have been assimilated by microorganisms or oxidized to $\mathrm{NO}_{3}^{-}$by nitrifiers.

Another informative parameter was the $\mathrm{NH}_{4}{ }^{+}-\mathrm{N}: \mathrm{NO}_{3}{ }^{-} \mathrm{N}$ ratio, with the lowest ratio observed in tilled soil, emphasizing the need for mineral $\mathrm{N}$ by the plants and soil microbial community during the blossom stage (Figure $12 \mathrm{E}$ ). Figure $12 \mathrm{E}$ also shows the high ammonium/nitrate ratio in the undisturbed Campo sujo soil. 


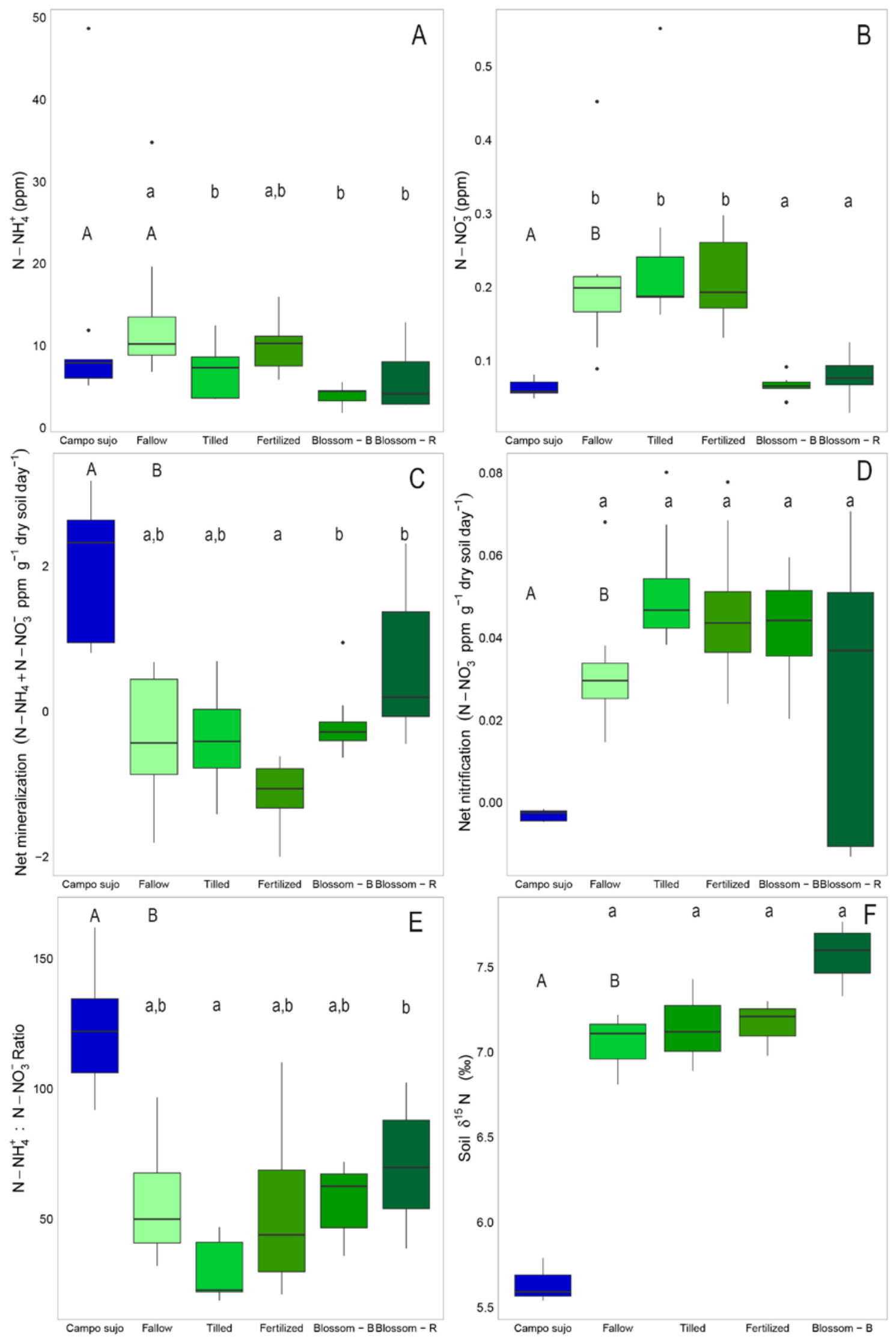

Figure 13. One-way ANOVA tests on soil $\mathrm{N}$ values, with Tukey-Kramer post hoc tests to compare group means ( $\mathrm{R}$ with the ggplot2 package). Concentrations of (A) $\mathrm{NH}_{4}{ }^{+}-\mathrm{N}$ and (B) $\mathrm{NO}_{3}{ }^{-} \mathrm{N}$ in soil samples under each condition. (C) Net mineralization and (D) nitrification 
determined by inorganic $\mathrm{N}$ and $\mathrm{NO}_{3}^{-}-\mathrm{N}$ content, respectively, measured after soil incubation in the laboratory for 1 week;(E) $\mathrm{NH}_{4}{ }^{+}-\mathrm{N}$ : $\mathrm{NO}_{3}{ }^{-} \mathrm{N}$ ratio and (F) integrated values of soil $\delta^{15} \mathrm{~N}$ (\%). Letters represent significant differences in inorganic $\mathrm{N}$ content between soil samples after post hoc tests: upper case letters represent difference between undisturbed Campo sujo and fallow soil from the soybean site; lower case letters present differences among soybean site samples. Soil samples obtained during the blossom stage of soybean development are represented by Blossom-B for bulk soil and Blossom-R for rhizosphere soil.

These results were supported by the integrated stable isotope ratios of $\mathrm{C}$ and $\mathrm{N}$ in these soils. The first soybean ( $\mathrm{C} 3$ plant) cultivation did not change the $\delta^{13} \mathrm{C}$ signal that remained from maize ( $C_{4}$ plant) cultivation or from the grassland before agriculture installation (Figure 13); however, the integrated soil $\delta^{15} \mathrm{~N}$ values were more labile. Soil $\delta^{15} \mathrm{~N}$ was significantly lower in the undisturbed Campo sujo soil than in fallow soil from the soybean site (Figure $12 \mathrm{~F}$ ). Although soil $\delta^{15} \mathrm{~N}$ did not significantly change during the soybean cultivation period, an increase was observed during the blossom stage ( $p$ value 0.0795 , results of ANOVA between samples from the soybean site) (Figure 12F). These integrated isotope values are congruent with instantaneous values for mineralization and nitrification obtained from each sample in which significant changes in $\mathrm{N}$ cycle dynamics were observed, compared to the adjacent undisturbed site.

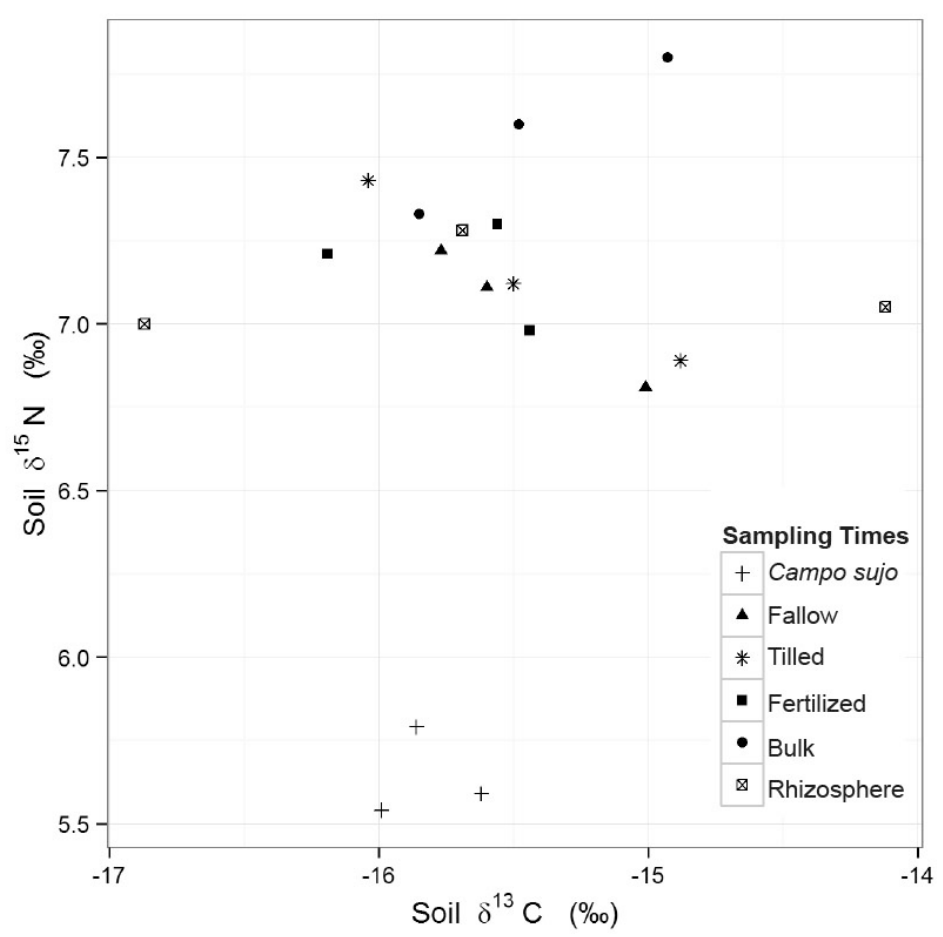

Figure 14. Relationship between soil $\delta^{13} \mathrm{C}$ and $\delta^{15} \mathrm{~N}$ in \%. Each point represents samples from each soil condition, marked with different symbols. 
Abundance of archaeal and bacterial amoA genes

Archaeal 16S rRNA and archaeal and bacterial amoA genes were amplified with specific primers to quantify the abundance of these genes in the undisturbed site and in the soybean site.

The mean abundances of $\mathrm{AOA}$ and $\mathrm{AOB}$ amoA genes in the undisturbed Campo sujo site were $3.4 \times 10^{5}$ and $1.6 \times 10^{3} \mathrm{~g}^{-1}$ dry soil, respectively, representing an average $A O A / A O B$ ratio of 212.9 (Figure $14 \mathrm{C}$ ). In addition, $\mathrm{AOA}$ and $\mathrm{AOB}$ were, respectively, 26 -fold and 49 -fold less abundant in the Campo sujo site than the soybean site during the fallow period (Figure 14). The thaumarchaeal 16S rRNA:archaeal amoA gene ratio in the Campo sujo site varied from 785 to 1340 and was significantly higher than that of fallow soil from the soybean site.

The abundance of thaumarchaeal 16S rRNA and bacterial amoA increased during soybean development, but AOA amoA gene abundance decreased by $45 \%$ in the tilled soil compared to fallow soil. Tillage did not have the same effect on AOB, as demonstrated by the lack of significant change in $A O B$ amoA gene abundance between fallow and tilled soil samples (Figure 14B). In fertilized soil AOA amoA gene abundance increased 2.6-fold and AOB amoA abundance increased 2-fold (Figure 14). However, AOB amoA gene abundance was more affected by soybean cultivation than AOA amoA gene abundance, as demonstrated by comparing rhizosphere soil with bulk soil during the blossom stage of soybean development. Furthermore, the increase in $A O B$ abundance from fallow soil to rhizosphere soil was 2.9 greater than the increase in AOA abundance. 

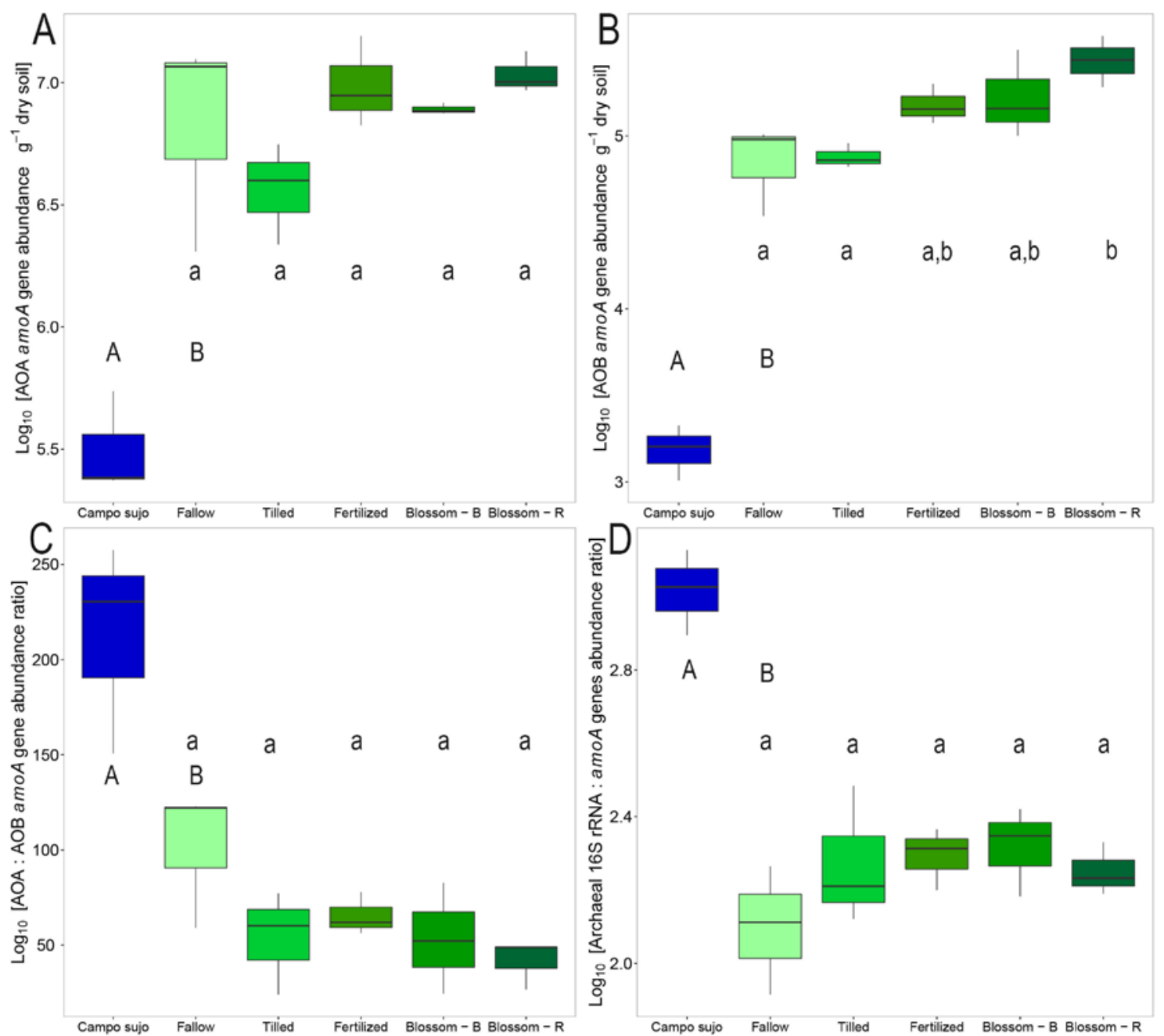

Figure 15. Changes in (A) AOA amoA gene abundance, (B) AOB amoA gene abundance, (C) AOA:AOB amoA gene abundance ratio, and (D) archaeal 16S rRNA:amoA gene abundance ratio. One-way ANOVA tests were performed, followed by Tukey-Kramer post hoc tests to compare group means ( $R$ package with the ggplot2 library). Different letters represent significant differences in gene abundance after post hoc tests: upper case letters represent difference between undisturbed Campo sujo and fallow soil from the soybean site; lower case letters present differences among soybean site samples. Soil samples obtained during the blossom stage of soybean development are represented by Blossom-B for bulk soil and Blossom-R for rhizosphere soil.

Soybean cultivation affected the abundance of both bacterial and archaeal ammonia oxidizers. The correlation between $\mathrm{pH}$ measured in $\mathrm{H}_{2} \mathrm{O}$ and $\log _{10}[\mathrm{AOB}]\left(\mathrm{R}^{2} 0.75, p\right.$ value $<0.05$ with the Bonferroni correction) was higher than the correlation between $\mathrm{pH}$ and $\log _{10}[A O A]\left(R^{2} 0.63, p\right.$ value $<0.05$ with the $B H$ correction). Similarly, the pattern of $\delta^{15}$ $\mathrm{N}$ was more strongly associated with $\log _{10}[\mathrm{AOB}]\left(\mathrm{R}^{2} 0.96, p\right.$-value $<0.05$ corrected by Bonferroni method) than with $\log _{10}[\mathrm{AOA}]\left(\mathrm{R}^{2} 0.88, p\right.$ value $<0.05$ with the Bonferroni correction). Nevertheless, when analyzing only soils from the soybean site, AOA abundance did not correlate with $\mathrm{pH}$, and the correlation between $\mathrm{pH}$ and $\mathrm{AOB}$ abundance was lower 
$\left(R^{2} 0.55, p\right.$ value $=0.72$ with the Bonferroni correction). Similarly, the correlation between $\delta^{15}$ $\mathrm{N}$ and $\log _{10}[\mathrm{AOA}]$ was not significant $\left(\mathrm{R}^{2} 0.24, p\right.$ value $=0.64$ corrected by $\mathrm{BH}$ method) when analyzing only soils from the soybean site, but the correlation was still significant between $\delta^{15} \mathrm{~N}$ and $\log _{10}[A O B]\left(R^{2} 0.68, p\right.$-value $<0.05$ with the $\mathrm{BH}$ correction $)$. 


\section{Discussion}

In assessing links between environmental characteristics, nitrification, and the abundance of ammonia-oxidizer communities in the soil, it is important to assess abundances of both $\mathrm{AOA}$ and $\mathrm{AOB}$, given the predominance of $\mathrm{AOA}$ amoA genes in many soils (Isobe 2012; Leininger 2006; Prosser and Nicol 2012). To assess the impact of land use conversion to soybean cultivation, ammonia oxidizer abundance and nitrification were evaluated in a soybean site after fallow, tillage, and fertilization and during the blossom stage of soybean development. These measurements were compared with those of an adjacent undisturbed Campo sujo site with low nitrate concentration, which is typical of Cerrado soil. These measurements support our hypothesis that both fertilization and soybean cultivation decrease the $A O A / A O B$ ratio in association with increases in pH (Nicol et al. 2008; Prosser and Nicol 2012) and inorganic $\mathrm{NH}_{4}{ }^{+}$(Levičnik-Höfferle et al. 2012), which is consistent with studies reporting that $\mathrm{AOA}$ are predominant in low-nutrient, low-pH environments (Erguder et al. 2009; Prosser and Nicol 2012). However, this study highlights the rapidity of changes in nitrifiers, $\mathrm{N}$ dynamics, and yields that occur in Cerrado soils after conversion to soybean cultivation.

The cultivation of soybeans in Brazil has been successfully implemented with inoculation of Bradyrhizobium strains to decrease or even completely eliminate the need for $\mathrm{N}$ fertilizers (Mendes et al. 2003). Nevertheless, the soybean site studied here required tillage and fertilization. Our results showed the effect of plant cover during the fallow period on soil recovery in the soybean site. Soil collected during the fallow period had soil characteristics similar to those of the undisturbed Campo sujo site, despite the different soil texture.

The undisturbed soil had the highest net $\mathrm{N}$ mineralization rate (average of $2 \mu \mathrm{g}$ $\mathrm{NH}_{4}{ }^{+}-\mathrm{N} \mathrm{g}^{-1}$ dry soil day ${ }^{-1}$ ) and the lowest net nitrification rate, suggesting the inhibition of nitrification or low abundance of nitrifiers despite the presence of $\mathrm{NH}_{4}{ }^{+} \mathrm{N}$. However, potential nitrification was negative, indicating that the microbial community used nitrate at a faster rate than it was produced by nitrification. The soil was incubated in plastic bags; nitrate loss through leaching is negligible. Denitrification is unlikely at the moisture content of the soil used, and previous studies report that the loss of $\mathrm{N}$ gases is undetectable in undisturbed Cerrado soils (Bustamante et al. 2006; Pinto et al. 2002).

Both $\mathrm{NH}_{4}{ }^{+}-\mathrm{N}$ and $\mathrm{NO}_{3}{ }^{-} \mathrm{N}$ concentrations were particularly low in the soybean site during the blossom stage of soybean development, possibly because of $\mathrm{N}$ uptake by the 
soybean plants. $\mathrm{N}$ mineralization exceeded immobilization in the rhizosphere soil but not in the bulk soil, which suggests greater $\mathrm{N}$ availability due to symbiotic $\mathrm{N}$ fixation. The soil C:N ratio > 20 (data not shown) in the bulk soil may partly explain the greater $\mathrm{N}$ immobilization, leading to depletion of $\mathrm{N}$ by both microbiota and plants. The decrease in $\mathrm{NH}_{4}{ }^{+}-\mathrm{N}$ and $\mathrm{NO}_{3}{ }^{-} \mathrm{N}$ during soybean growth was expected and is associated with periods of intense plant growth (Cruvinel et al. 2011). Nevertheless, Cruvinel et al. (2011) reported higher concentrations of $\mathrm{NO}_{3}^{-}{ }^{-} \mathrm{N}$ (1-52 mg kg-1, depending on the period) and $\mathrm{NH}_{4}{ }^{+}-\mathrm{N}(21.3-50.7 \mathrm{mg}$ $\mathrm{NH}_{4}{ }^{+}-\mathrm{N} \mathrm{kg}^{-1}$ soil) in soils during soybean cultivation higher than the levels of $\mathrm{NO}_{3}^{-}{ }^{-} \mathrm{N}$ and $\mathrm{NH}_{4}{ }^{+} \mathrm{N}$ concentration in the soybean site in recovery, supporting our finding that the soils sampled in our study were relatively depleted in mineral N. Cruvinel et al. (2011)also discussed possible competition between plant roots and microorganisms in the planted rows during cotton cultivation in the Cerrado because of the lower inorganic $\mathrm{N}$ availability and NO-N fluxes than that observed between rows. Low abundance of $A O A$ and $A O B$ in Cerrado soils may be due to competition with soil fungi for ammonium or inhibition by bioactive compounds synthesized by fungi (Yu et al. 2014). Nardoto and Bustamante (2003) showed that in both burned and unburned Cerrado areas, inorganic $\mathrm{N}$ content decreases during the rainy season, despite the observed increase in net $\mathrm{N}$ mineralization and net nitrification after the first rainfall events of the dry season (Nardoto and Bustamante 2003). These studies are consistent with our findings, as soils have higher levels of ammonia than nitrate, and the ammonium:nitrate ratio was lowest in the tilled soil, likely due to $\mathrm{N}$ release from organic matter. Similarly, the ammonium:nitrate ratio is high in integrated agricultural systems in Cerrado but is lower in crop-livestock and crop-livestock-forest systems compared to agroforestry and exotic pasture (Carvalho et al., personal communication). The same study also reports higher $\mathrm{N}_{2} \mathrm{O}$ emissions from all of these agricultural systems compared with native Cerrado soils, with crop-livestock having the highest levels (Carvalho et al., personal communication).

Despite lower soil nitrate concentrations than those reported by other studies, $\mathrm{N}$ losses from the soybean site compared with the undisturbed Campo sujo site are suggested by higher $\delta^{15} \mathrm{~N}$ values and greater nitrate accumulation in the managed system. The integrative soil $\delta^{15} \mathrm{~N}$ signal, which provides historical information on soil $\mathrm{N}$ dynamics, indicates that soybean cultivation affects soil $\mathrm{N}$ accumulation, as the expected values for symbiotic $\mathrm{N}$ fixation were lower, at 0-2\% (Delwiche et al. 1979). Nonetheless, the results demonstrate the labile characteristics of $\mathrm{N}$ compared to $\mathrm{C}$, as $\delta^{15} \mathrm{~N}$ tended to increase during soybean cultivation, changing the short-term $\mathrm{N}$ dynamics in the cultivated soil, 
whereas no significant changes in $\delta^{13} \mathrm{C}$ were observed. A recent study reported that the $\delta^{15} \mathrm{~N}$ signature reflects a strong pattern of change according to land use, mainly due to soil $\mathrm{C}$ dynamics and clay content (Craine JME 2015).

Many soil characteristics are associated with changes in soil nitrification, including $\mathrm{pH}$ (Gubry-Rangin et al. 2011; Nicol et al. 2008), $\mathrm{NH}_{3}$ and $\mathrm{NH}_{4}{ }^{+}$concentration (LevičnikHöfferle et al. 2012; Stopnisek 2010), $\mathrm{O}_{2}$ (Erguder et al. 2009), temperature (Tourna 2008), soil moisture (Placella and Firestone 2013; Thion and Prosser 2014), and organic C (Erguder et al. 2009); however, $\mathrm{pH}$ and ammonia concentration have received greatest attention as potential drivers of ammonia oxidizer communities (Prosser and Nicol 2012). Kinetic studies of ammonia oxidation by Nitrosopumilus maritimus suggest that AOA have a higher affinity for ammonia (Martens-Habbena et al. 2009), but AOA may also be more sensitive than $A O B$ to inhibition by high ammonia concentration (Prosser and Nicol 2012). In terms of pH, there is strong evidence for the selection of AOA, rather than AOB, in acid soils (Gubry-Rangin et al. 2011; Nicol et al. 2008; Zhang et al. 2012). However, AOA also contribute to nitrification in soils with pH > 5.5 (Gubry-Rangin et al. 2011; Gubry-Rangin et al. 2010), and there is evidence for long-term pH selection of both $\mathrm{AOB}$ and AOA phylotypes in soil (Nicol et al. 2008; Stephen et al. 1998). The increased pH observed during soybean cultivation was associated with a lower $A O A: A O B$ ratio in our study, but no significant effect on nitrification was detected, and the expected decrease in $\mathrm{pH}$ that frequently accompanies nitrification was not observed. This may be due to liming or the low rates of ammonia oxidation observed in these soils. Therefore, $\mathrm{pH}$ may limit ammonia oxidizer growth in these low-nitrate Cerrado soils.

In this study we observed that tillage, fertilization, liming, and soybean monoculture altered soil $\mathrm{pH}$, moisture, and inorganic $\mathrm{N}$ contents, all of which can influence the abundance and diversity of microbial communities and their functional potential, thereby influencing the production of nitrate, nitrite, $\mathrm{NO}$, and $\mathrm{N}_{2} \mathrm{O}$ (Mao et al. 2011). The change in land use had differential effects on the abundance of $A O A$ and $A O B$ communities, reinforcing the idea that these two microbial groups have distinct ecological niches associated with environmental variables. Specifically, samples from recently tilled soil and soil collected from the rhizosphere had smaller $A O A: A O B$ ratios, and $A O B$ showed a greater response to changes occurring during soybean cultivation. The lower abundance of AOA in undisturbed soil can be also related to the higher thaumarchaeal $16 \mathrm{~S}$ rRNA:archaeal amoA ratio, which, in the absence of primer bias, indicates a great abundance of non-ammoniaoxidizing Thaumarchaeota (e.g., belonging to group 1.1c) (Weber et al. 2015). 
A recent metagenomic study reported that Thaumarchaeota representatives were more abundant in no-till soils than in soils under conventional tillage (Souza et al., 2013), possibly because of greater organic matter content or sensitivity to tillage. Although the AOA amoA gene was more abundant in all of our soil samples, the increase in AOB amoA abundance in tilled soil was greater. This finding may reflect the disruption of soil structure and release of $\mathrm{C}$ and $\mathrm{N}$ substrates previously not available to the microbiota.

Our results provided evidence for our hypothesis that both $\mathrm{AOA}$ and $\mathrm{AOB}$ abundance increase during soybean cultivation, with $A O B$ increasing more than $A O A$, as predicted. Although AOA were more abundant, nitrification was better explained by the increase in $A O B$ abundance, as predicted by the current view that $A O B$ contribute more to ammonia oxidation than AOA in fertilized oxic soils at near-neutral pH. Wertz et al. (2012) reported an increase in $A O B$ abundance with fertilizer application and nitrification in pine forests (Wertz et al. 2012).AOB abundance was more highly correlated with potential nitrification (Meyer et al. 2014), indicating that other factors can influence ammonia oxidizer communities. Moreover, although AOA abundance is potentially stable during the cultivation of bioenergy crops (Zea mays and Miscanthus giganteus), AOA diversity decreases, and $A O B$ abundance increases, with this differential response to fertilization by $A O A$ and $A O B$ observed even 2 years after the fertilization (Mao et al. 2011).

A similar increase in the abundance of $A O B$, rather than $A O A$, was reported for a fertilized maize crop (Mao et al. 2011), and Mendes et al. (2014) recently showed that soybean plants select for the rhizosphere a specific subset of the soil bulk microbial community, which appears to be related to growth promotion and nutrition (Mao et al. 2011; Mendes 2014). Further studies are required to elucidate the differential effect of soybean cultivation on $A O A$ and $A O B$ abundance to determine whether these differences are direct effects of the soybean plant or due to fertilization promoting the growth of AOB. 


\title{
Chapter 4 - Ammonia oxidizers in a non-nitrifying Brazilian savanna soil ${ }^{4}$
}

"Guid gear comes in sma' bulk."

Scottish saying

\begin{abstract}
Nitrification rate in tropical Brazilian savanna (Cerrado) soil is low to undetectable, puzzling researchers for decades. It was proposed that inhibitors in these soils, potentially produced by plants, could hamper ammonia oxidation. Recently we linked the absence of nitrification in an undisturbed Cerrado soil to low soil $\mathrm{pH}$ and a significantly lower abundance of archaeal $(A O A)$ and bacterial $(A O B)$ ammonia oxidizers than an adjacent Cerrado site changed to agriculture management. We also hypothesized that rain after the dry season allows higher microbial activity, including organic nitrogen mineralization and subsequent ammonia oxidation. To test these hypotheses, we (i) manipulated moisture and $\mathrm{pH}$ in microcosms containing Cerrado soil and (ii) tested nitrification inhibition in slurries assembled with a mixture of Cerrado and agricultural soil known for actively oxidizing ammonia. Very little $\mathrm{NO}_{3}{ }^{-}$accumulation was observed in Cerrado microcosms with either increasing moisture or $\mathrm{pH}$, despite high ammonia concentration. In the Cerrado slurries, AOA amoA transcripts were detected after 14 and 21 days but not in all replicates. Besides, nitrification was not inhibited in the mixed soil slurries, final $\mathrm{NO}_{3}^{-}$content being proportional to initial agricultural/Cerrado soil ratios, indicating a dilution of the ammonia oxidizer community, but no inhibition. In addition, DGGE profiles of the AOA community were similar in the mixed and nitrifying soils. Together, these results suggest that neither water availability, ammonia availability, low $\mathrm{pH}$ nor inhibition by soil compounds constrained nitrification in Cerrado soils. This distinctive pattern, i.e. the absence of nitrification despite the presence of $A O A$ and $A O B$, might be associated with a particular community, specialized in high $\mathrm{N}$ immobilization in organic matter rather than in $\mathrm{N}$ loss through nitrification.
\end{abstract}

\footnotetext{
${ }^{4}$ Catão, E. C. P.; Thion, C.; Prosser, J. I. \& Krüger, R. H. (2016) Ammonia oxidizers in a non-nitrifying Brazilian savanna soil. To be submitted to FEMS Microbiology Ecology.
} 


\section{Introduction}

Nitrification, the sequential oxidation of ammonia to nitrite and nitrate, is a major cause of $\mathrm{N}$ loss in terrestrial environments, especially in agricultural systems, where $95 \%$ of total $\mathrm{N}$ is transformed through nitrification and denitrification, potentially leading to nitrate $\left(\mathrm{NO}_{3}^{-}\right)$leaching and emission of nitric (NO) and nitrous $\left(\mathrm{N}_{2} \mathrm{O}\right)$ oxides. In these systems the use of synthetic inhibitors of nitrification decreases nitrogen losses (Powell and Prosser, 1992). These inhibitors target the first step in nitrification, ammonia oxidation, which is carried out by both bacterial and archaeal ammonia oxidizers. In contrast, some natural systems have lower rates of nitrification and higher nitrogen use efficiency than managed systems (Ste-Marie and Paré, 1999). An example is the tropical savanna biome in Central Brazil, also called Cerrado, which has low to undetectable $\mathrm{NO}_{3}{ }^{-}$concentration (Nardoto and Bustamante, 2003), high $\mathrm{NH}_{4}{ }^{+}: \mathrm{NO}_{3}^{-}$ratio and low abundance of nitrifiers (Catão et al., 2016). These ecosystems may therefore provide a model for greater and more sustainable crop productivity and reduced demand for nitrogen fertilizers.

There are several potential explanations for low nitrification rates. Plants may reduce nitrification rates through competition for $\mathrm{NH}_{4}{ }^{+}-\mathrm{N}$, supply of carbon from the plant, increasing C:N ratio and promoting higher rates of immobilization, or through inhibitory compounds in plant litter and root exudates (Subbarao et al., 2006). More specifically, some plants release biological nitrification inhibitors $(\mathrm{BNI})$ to the rhizosphere. These compounds target ammonia oxidation and reduce competition for ammonium by ammonia oxidizers (Subbarao et al., 2006; Subbarao et al., 2015), although the relatively high ammonium concentrations in Cerrado soil (3 - 22 ppm (Nardoto and Bustamante, 2003); 5 - 49 ppm (Catão et al., 2016)) suggest that ammonia oxidizers are not limited by ammonia concentration. In addition, $\mathrm{BNI}$-compounds are released by roots of plants grown with $\mathrm{NH}_{4}{ }^{+}$ but not with $\mathrm{NO}_{3}^{-}$(Subbarao et al., 2009), which could explain the inhibition of ammonia oxidation in the Cerrado soils.

Low rates of nitrification in acidic soils have been described for many years (De Boer and Kowalchuk, 2001) and rates often increase when acidic soils are amended with bases such as calcium carbonate (Fraps and Sterges, 1932), as also shown in Cerrado soil (Rosolem et al., 2003). Inhibition of ammonia oxidation at low pH was traditionally considered to be due to the low availability of ammonia $\left(\mathrm{NH}_{3}\right)$, through ionization to $\mathrm{NH}_{4}{ }^{+}$, but may be alleviated in soil by growth in aggregates or on surfaces (Allison and Prosser, 1993; De Boer 
et al., 1991), urease activity (Burton and Prosser, 2001; de Boer et al., 1989) or through growth of acidophilic archaeal ammonia oxidizers (Gubry-Rangin et al., 2011; LehtovirtaMorley et al., 2011) at low pH.

Low water availability also reduces nitrification rate (Placella and Firestone, 2013; Thion and Prosser, 2014). The Cerrado biome has well defined dry and wet seasons, and rainfall or artificial water addition results in $\mathrm{N}_{2} \mathrm{O}$ pulses and 10-times more $\mathrm{NO}$ emission (Pinto et al., 2006; Pinto et al., 2002), leading to the hypothesis that ammonia oxidation can be limited during dry seasons in this biome.

Reasons for low nitrification rates in the Cerrado biome are unclear, but both archaeal and bacterial ammonia oxidizers are present in these soils (Catão et al., 2016). The aim of this study was to test three hypotheses for potential mechanisms explaining low rates of nitrification. The first, the presence of plant-derived nitrification inhibitors, was tested by (i) analysis of the growth of cultures of ammonia oxidising bacteria (AOB) and archaea ( $A O A)$ in the presence of Cerrado soil aqueous extract, and (ii) by the effect of increasing amounts of Cerrado soil on ammonia oxidation by a nitrifying soil (Craibstone) in soil slurries. To second and third hypotheses, nitrification inhibition by low water availability or low $\mathrm{pH}$, respectively), were tested by manipulation of Cerrado soil water content and $\mathrm{pH}$ in microcosms. 


\section{Materials and methods}

\section{Soil sampling}

Triplicate soil samples were obtained from the upper $10 \mathrm{~cm}$ at each site and were pooled before sieving (2-mm mesh size) and stored at $4{ }^{\circ} \mathrm{C}$. Cerrado soil was sampled from an undisturbed shrubland, termed Campo sujo, described previously (Catão et al., 2016). The average monthly precipitation and temperature at this site, measured at the nearest meteorological center in 2014 ( $30 \mathrm{~km}$ from the farm; Pirenopolis - GO, Station 83376, $15^{\circ} 50^{\prime} 60^{\prime \prime} \mathrm{S} 48^{\circ} 57^{\prime} 36^{\prime \prime} \mathrm{W}$ ), were $143 \mathrm{~mm}$ (range $0-317 \mathrm{~mm}$ ) and $23.4^{\circ} \mathrm{C}$ (range $21-25.6^{\circ} \mathrm{C}$ ), respectively. The climate in the Cerrado biome is tropical (Köppen Aw) and samples were collected at the beginning of the dry season (May 2014). The soil, well-aerated and welldrained, is classified as sandy loam with $20.8 \%$ clay and had an initial pH of $5.6( \pm 0.04)$. Craibstone soil, used in this study as a reference nitrifying soil, was sampled from an experimental agricultural field (Scottish Agricultural College, Craibstone, Scotland, Grid reference NJ872104), maintained at pH 5.5 since 1961.

Cultures with or w/o soil aqueous extracts

Craibstone and Campo sujo soil aqueous extracts were prepared by blending $20 \mathrm{~g}$ soil in 2 volumes of sterile distilled water for $40 \mathrm{~s}$ and rotating in $50 \mathrm{~mL}$ sterile tubes for $1 \mathrm{~h}$. Aqueous extracts were then obtained by centrifugation (3,000 x $\mathrm{g}$ for $15 \mathrm{~min}$ ) and sterilised by progressive filtration through 10-mm, $5-\mathrm{mm}, 0.45-\mu \mathrm{m}$ and $0.22-\mu \mathrm{m}$ size pore filters. $\mathrm{NH}_{4}{ }^{+}$ and $\mathrm{NO}_{3}{ }^{-}$concentrations in the filtrates were below the level of detection (data not shown).

Pure strains of AOA ("Candidatus Nitrosocosmicus franklandia") and AOB (Nitrosospira briensis, Nitrosospira tenuis, Nitrosospira multiformis and Nitrosomonas europaea) were cultivated in the dark without shaking, in inorganic growth medium. 'Candidatus Nitrosocosmicus franklandia' (paper in revision) was cultivated at $40{ }^{\circ} \mathrm{C}$ in a previously described medium (Lehtovirta-Morley et al., 2011) modified by addition of $1 \mathrm{~mL} \mathrm{~L}^{-1}$ vitamin solution (Widdel and Bak, 1992), $1 \mathrm{~mL} \mathrm{~L}^{-1}$ selenite-tungstate solution (Widdel and Bak, 1992) and $2 \mathrm{mM} \mathrm{NH}_{4} \mathrm{Cl}$. pH was maintained at 7.5 by addition of $10 \mathrm{~mL} \mathrm{~L}^{-1} 1 \mathrm{M} \mathrm{HEPES}$ buffer. AOB were grown in SW medium (Skinner and Walker, 1961) at $30{ }^{\circ} \mathrm{C}$. Triplicate cultures were prepared in $30 \mathrm{~mL}$ universal tubes by adding $5 \mathrm{~mL}$ of the appropriate medium previously inoculated with an exponentially growth culture $(1 \mathrm{~mL}$ of innocula per $100 \mathrm{~mL} 2 \mathrm{x}$ concentrated medium) to other $5 \mathrm{~mL}$ medium of either sterile distilled water, Craibstone or Campo sujo soil aqueous extracts, or $100 \mu \mathrm{M}$ allylthiourea (ATU) (final concentration), a 
commercial ammonia oxidizer inhibitor. without agitation (Figure 15). Growth was monitored during 26 days $(A O A)$ and 13 days $(A O B)$ by measuring nitrite accumulation (Shinn, 1941) and maximum specific growth rate was estimated as the slope of semilogarithmic plots of nitrite concentration vs time.

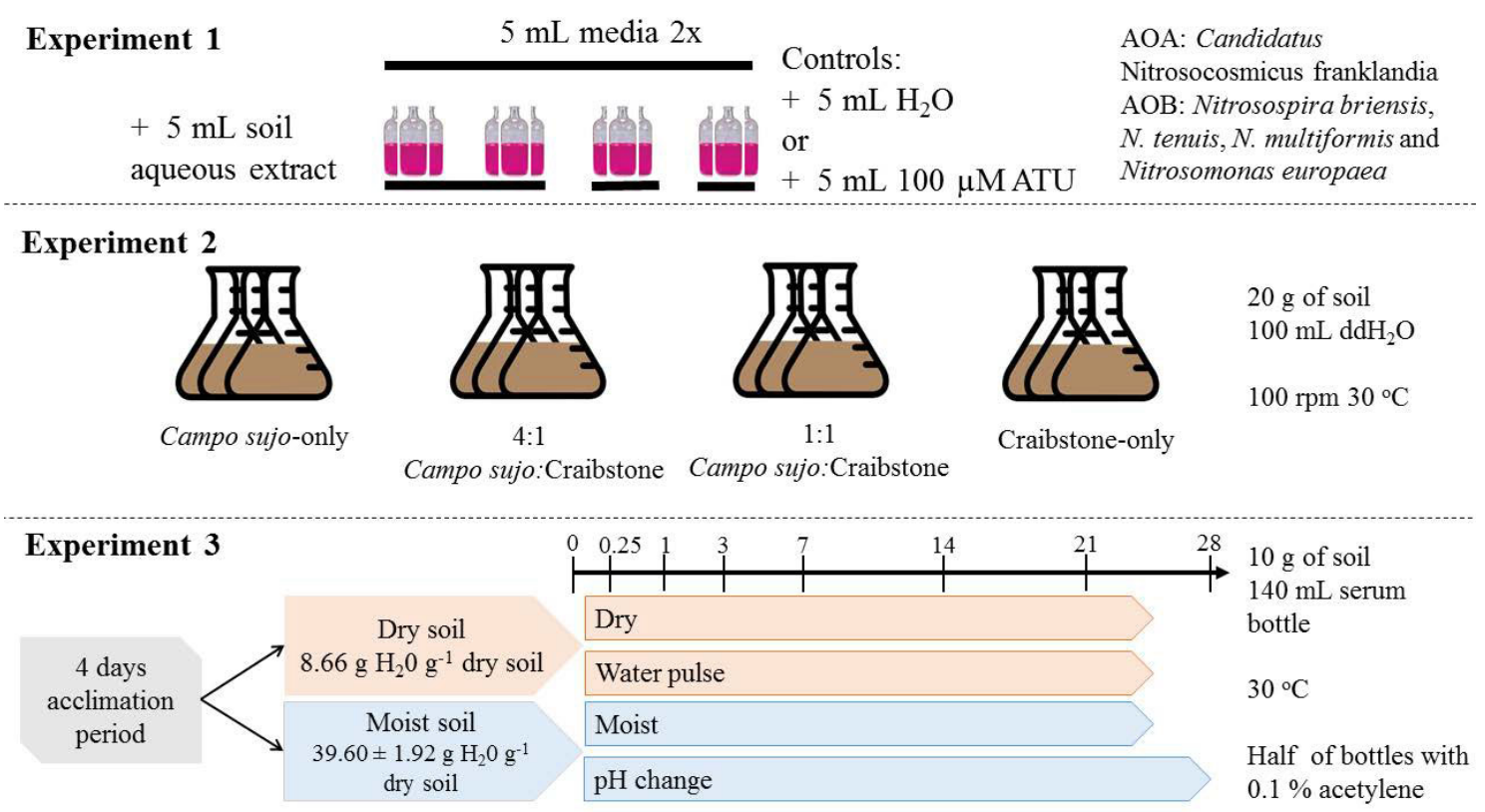

Figure 16. Graphical representation of the three experimental designs.

Soil incubation in slurries

Soil slurries were established in $250-\mathrm{ml}$ sterile Erlenmeyer flasks containing $20 \mathrm{~g}$ soil and $100 \mathrm{~mL}$ sterile distilled water, stirred at $100 \mathrm{rpm}$ and maintained at $30{ }^{\circ} \mathrm{C}$ in the dark (Figure 15). Flasks contained either Campo sujo soil, Craibstone soil or 1:1 or 4:1 ratios of Campo sujo and Craibstone soils. Soil slurry samples $(8 \mathrm{~mL})$ were centrifuged at 3,000 $\mathrm{xg}$ for 15 min. Supernatant $(2 \mathrm{~mL})$ was used for immediate measurement of $\mathrm{pH}$, while the remaining supernatant $\left(6 \mathrm{~mL}\right.$ ) was stored at $-20{ }^{\circ} \mathrm{C}$ for quantification of inorganic $\mathrm{N}$ (see below). The soil pellet was frozen in liquid nitrogen and stored at $-80{ }^{\circ} \mathrm{C}$ for nucleic acid analysis.

\section{Soil incubation in microcosms}

Cerrado Campo sujo soil was incubated in sealed microcosms consisting of 140-ml sterile serum glass bottles containing $10 \mathrm{~g}$ soil (Figure 15 ). Soil had an initial water content of $24.9 \pm 0.03 \mathrm{~g} \mathrm{H}_{2} \mathrm{O} \mathrm{g}^{-1}$ dry soil, corresponding to a matric potential of $-0.15 \pm 0.01 \mathrm{MPa}$. Microcosms were incubated for 4 days in the dark at $30^{\circ} \mathrm{C}$ (acclimation period), and then 
divided in two groups. One group was left to air-dry, reaching a moisture content of $8.66 \mathrm{~g}$ $\mathrm{H}_{2} \mathrm{O} \mathrm{g}^{-1}$ dry soil $(-6.34 \pm 2.98 \mathrm{MPa}$ matric potential), while the moisture content of the other was adjusted to $37.9 \pm 0.3 \mathrm{~g} \mathrm{H}_{2} \mathrm{O} \mathrm{g}^{-1}$ dry soil by addition of sterile distilled water. Soil in half of the 'dried soil' microcosms was rewetted to $39.6 \pm 1.92 \mathrm{~g} \mathrm{H}_{2} \mathrm{O} \mathrm{g}^{-1}$ dry soil ( $-0.11 \pm 0.02 \mathrm{MPa}$ ) ('Water Pulse' treatment), while soil in the remaining microcosms was kept dry ('Dry' treatment). Finally, the $\mathrm{pH}$ of soil in half of the moist soil microcosms was increased to 6.34 \pm 0.09 with $\mathrm{CaCO}_{3}$ (' $\mathrm{pH}$ ' treatment hereafter). The $\mathrm{pH}$ of soil in the remaining microcosms ('Dry', 'Water Pulse' and 'Moist' treatments) was $5.21 \pm 0.02$, which was slightly lower than the initial value of sampled soil, and was not adjusted. The four treatments were performed in triplicates, with or without addition of acetylene ( $0.01 \%$ of headspace volume). Microcosms were sampled destructively after $6 \mathrm{~h}$ and 1, 3, 7, 14 and 21 days (an additional time after 28 days was included for the $\mathrm{pH}$ treatment). For each microcosm, half of the soil was stored at $-80^{\circ} \mathrm{C}$ for molecular analysis and the remaining soil was used for chemical analysis. Microcosms were incubated in the dark at $30^{\circ} \mathrm{C}$ and aerobic conditions were maintained by removing seals for 5 - 10 minutes twice weekly. 'Moist' and 'Water Pulse' microcosms were watered weekly to maintain moisture content.

Soil physicochemical analyses

Water matric potential was measured using a WP4C Dewpoint PotentiaMeter (Decagon, Pullman, UK) and $\mathrm{pH}$ was determined in water. Soil $\mathrm{NH}_{4}{ }^{+}$and $\mathrm{NO}_{\mathrm{x}}\left(\mathrm{NO}_{2}{ }^{-}+\mathrm{NO}_{3}{ }^{-}\right.$) concentrations were determined colorimetrically by flow injection analysis (FIA star 5010 Analyser, Foss Tecator AB, Höganäs, Sweden) (Allen, 1989) after extraction from $2 \mathrm{~g}$ of wet soil in $10 \mathrm{ml}$ of $1 \mathrm{M} \mathrm{KCl}$ for the microcosm soil, or directly from slurry supernatant. As $\mathrm{NO}_{2}^{-}$ concentration was below the level of detection, $\mathrm{NO}_{x}$ is expressed as $\mu \mathrm{g} \mathrm{NO}_{3}{ }^{-} \mathrm{N} \mathrm{g}^{-1}$ dry soil (ppm). Inhibition was assessed as the percentage reduction in nitrate concentration in comparison to that of Craibstone soil at each time point.

\section{Molecular analysis}

Nucleic acids were extracted from $0.5 \mathrm{~g}$ soil as previously described (Nicol et al., 2005), suspended in DEPC-treated water and immediately stored at $-80{ }^{\circ} \mathrm{C}$. CDNA was produced from an aliquot by DNAse treatment and RNA reverse-transcription as described previously (Tourna, 2008). Nucleic acid not used to for CDNA generation was considered as DNA only and the concentration was estimated using a NanoDrop 1000 Spectrophotometer (Thermo Scientific, Loughborough, UK). 
Archaeal and bacterial amoA genes were quantified in MasterCycler (Eppendorf), using standard curves as reference based on fragments obtained as described previously (Catão et al., 2016) and primers crenamo23f and crenamo616r (Tourna, 2008) and bacterial amoA with amoA1F and amoA2R (Rotthauwe et al., 1997), respectively. Each reaction had a final volume of $20 \mu \mathrm{l}$ containing $1 \mathrm{X}$ QuantiFast (for AOA) or QuantiTect (for AOB) (Qiagen), $0.4 \mu \mathrm{M}(\mathrm{AOA} a \mathrm{moA})$ or $0.6 \mu \mathrm{M}$ (AOB amoA) of each primer, $2 \mu \mathrm{g} \mathrm{\mu l}^{-1} \mathrm{BSA}$ (Promega) and $2 \mu \mathrm{L}$ of DNA (or cDNA). Archaeal amoA genes and transcripts were amplified according to the cycling conditions: $15 \mathrm{~min}$ at $95^{\circ} \mathrm{C}$, followed by 40 cycles of $15 \mathrm{~s}$ at $94^{\circ} \mathrm{C}, 1 \mathrm{~min} 30 \mathrm{~s}$ at $60^{\circ} \mathrm{C}$. AOB amoA genes were amplified using the following cycling conditions: $15 \mathrm{~min}$ at $95^{\circ} \mathrm{C}, 45$ cycles of $1 \mathrm{~min}$ at $94^{\circ} \mathrm{C}, 1 \mathrm{~min}$ at $55^{\circ} \mathrm{C}, 1 \mathrm{~min}$ at $72^{\circ} \mathrm{C}$. SybrGreen fluorescence was measured after $5 \mathrm{~s}$ at $80{ }^{\circ} \mathrm{C}$ or $8 \mathrm{~s}$ at $83^{\circ} \mathrm{C}$, for $\mathrm{AOA}$ and $\mathrm{AOB}$, respectively, to exclude fluorescence contamination of potential primer-dimers. Melting curves between $65^{\circ} \mathrm{C}$ and $95{ }^{\circ} \mathrm{C}$ were analysed for each run. AOB amoA transcripts were below the detection limit ( $5 \operatorname{copies}^{\prime-1} \mathrm{l}^{-1}$. Efficiency of amplification and $r^{2}$ for DNA were, respectively, 0.92 and 0.998 for archaeal amoA and 104.6 and 0.993 for bacterial amoA.

AOA community composition in soil slurries was assessed by denaturing gradient gel electrophoresis (DGGE) analysis of amoA genes using the above primers in a linear gradient of $15-55 \%$ denaturant, as described previously (Nicol et al., 2005).

\section{Statistical analysis}

All analyses were conducted using $R$ version (3.2.2). The effect of soil aqueous extracts on pure $A O A$ and $A O B$ cultures was analysed by testing the difference between specific growth rates with a one-way analysis of variance (ANOVA) between treatments. The significance of differences between nitrification rates in soil slurries was tested using a linear mixed model (package nlme) (Pinheiro et al., 2015) for repeated measures. Each slurry was considered a subject with random effect to analyse the effect of the fixed factors, i.e. treatment (mixed soil, Campo sujo or Craibstone slurries), time and their interaction, over the response variables: inorganic $\mathrm{N}$ concentration and amoA gene (and transcript) abundance. $\mathrm{NO}_{3}{ }^{-}$concentration in the Campo sujo slurries was below the limit of detection, and these samples were excluded from the analysis. Gene abundance data were logtransformed to achieve a normal distribution. When the interaction between the independent variables was not significant, it was removed to analyse the effect of time or treatment over the concentration independently. Two-way ANOVAs, with treatment and 
time as independent factors, were performed to evaluate statistical differences in mineralization and $\mathrm{NO}_{3}{ }^{-}$in microcosms. 


\section{Results}

Effects of soil extracts on ammonia oxidizer cultures

To assess the presence of potential nitrification inhibitors in soil, pure cultures of four $A O B$ and one $A O A$ were grown in liquid batch culture in medium amended with aqueous extracts. Soil aqueous extracts from both Campo sujo and Craibstone soils had no significant effect on the growth of any of the AO strains tested (Figure 16). Allylthiourea was used as a control for inhibition at $100 \mu \mathrm{M}$ final concentration and completely inhibited all $A O B$ cultures tested but interestingly did not inhibit growth of the AOA, Candidatus N. franklandia (Figure 16).

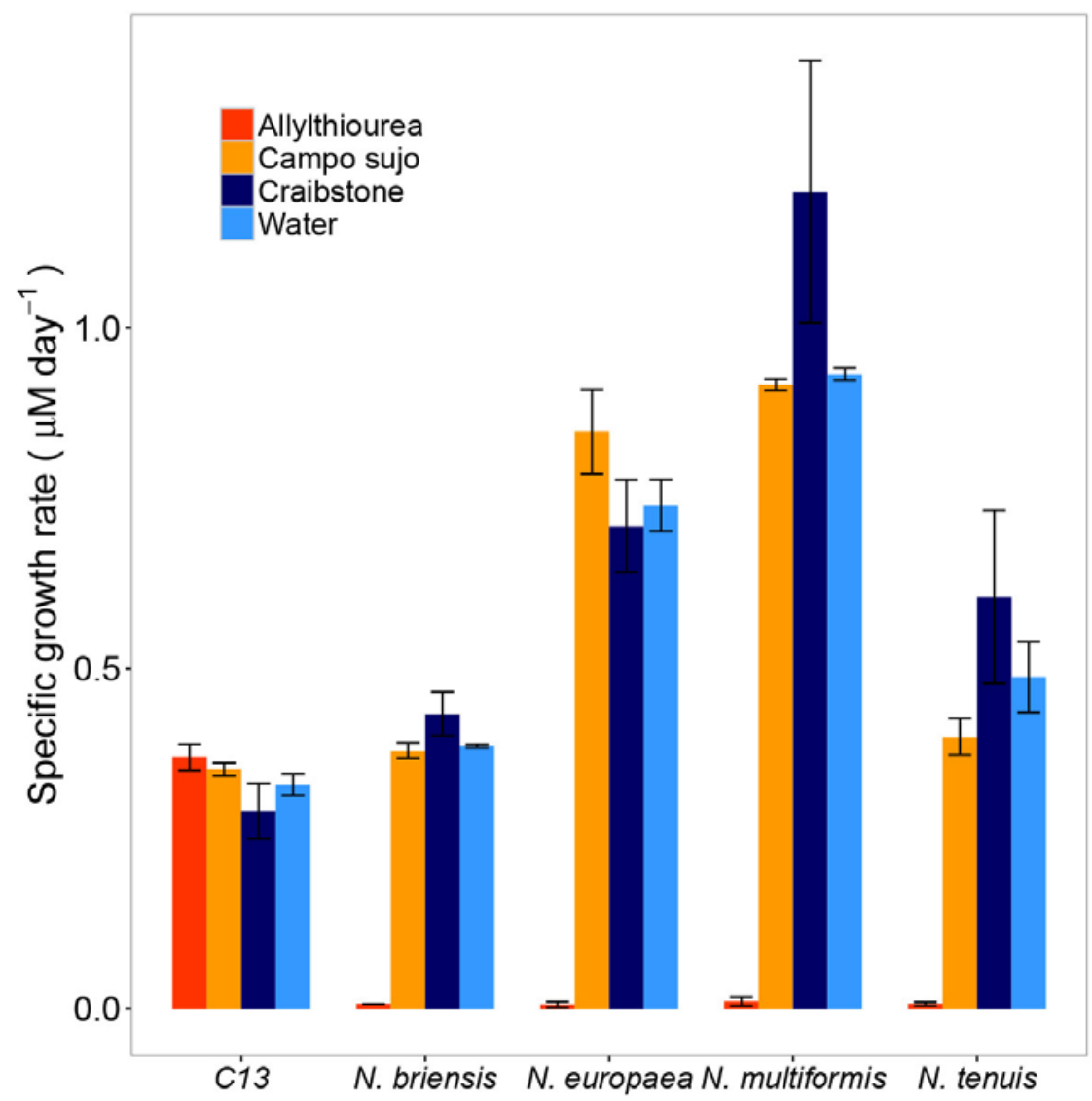

Figure 17. Specific growth rate calculated during exponential nitrite production batch cultures of the soil $\mathrm{C} 13$ and four soil AOB (Nitrosospira briensis, Nitrosomonas europaea, Nitrosospira multiformis, Nitrosospira tenuis) after addition of water (control), aqueous extracts of Campo sujo or Craibstone soil or $100 \mu \mathrm{M}$ allylthiourea. Error bars represent standard errors of the means from triplicate cultures. 


\section{Effects of Campo sujo soil on nitrification in Craibstone soil}

Soil slurries were established with mixtures of Campo sujo and Craibstone soils at ratios of 1:1 to $4: 1$, and with each soil alone, and were incubated in for 21 days. In all slurries, pH increased slightly after the first day of incubation, but did not change significantly during subsequent incubation.

Net $\mathrm{NH}_{4}{ }^{+}$accumulation in the microcosms after 21 days ranged from $0.62( \pm 0.02)$ to $1.76( \pm 0.39)$ ppm for Craibstone and $0.87( \pm 0.02)$ ppm to $2.20( \pm 0.02)$ for Campo sujo (Figure 17). Ammonium concentrations were greater in mixed slurries than in controls, but accumulated less $\mathrm{NH}_{4}{ }^{+}$during incubation, and the increase in $\mathrm{NH}_{4}{ }^{+}$concentration after 21 days was greatest (2.9-fold) in Craibstone soil.

$\mathrm{NO}_{3}^{-}$accumulated in all soil slurries ( $p<0.0001$, Figure $17 \mathrm{~B}$ ) except those containing Campo sujo-only, in which no $\mathrm{NO}_{3}{ }^{-}$was below the detection limit. In the mixed slurries, $\mathrm{NO}_{3}{ }^{-}$ production was equivalent or higher than the 50\% and 20\% expected for the 1:1 and 4:1 slurry (Figure 17 C), thereby providing no evidence for inhibition of Craibstone soil nitrification by Campo sujo soil. Furthermore, the variance among replicate slurries (intra-treatment) was greater than 0 , therefore significant, but smaller than the variance associated between subjects (inter-treatment) for both the ammonia and $\mathrm{NO}_{3}{ }^{-}$concentrations. 

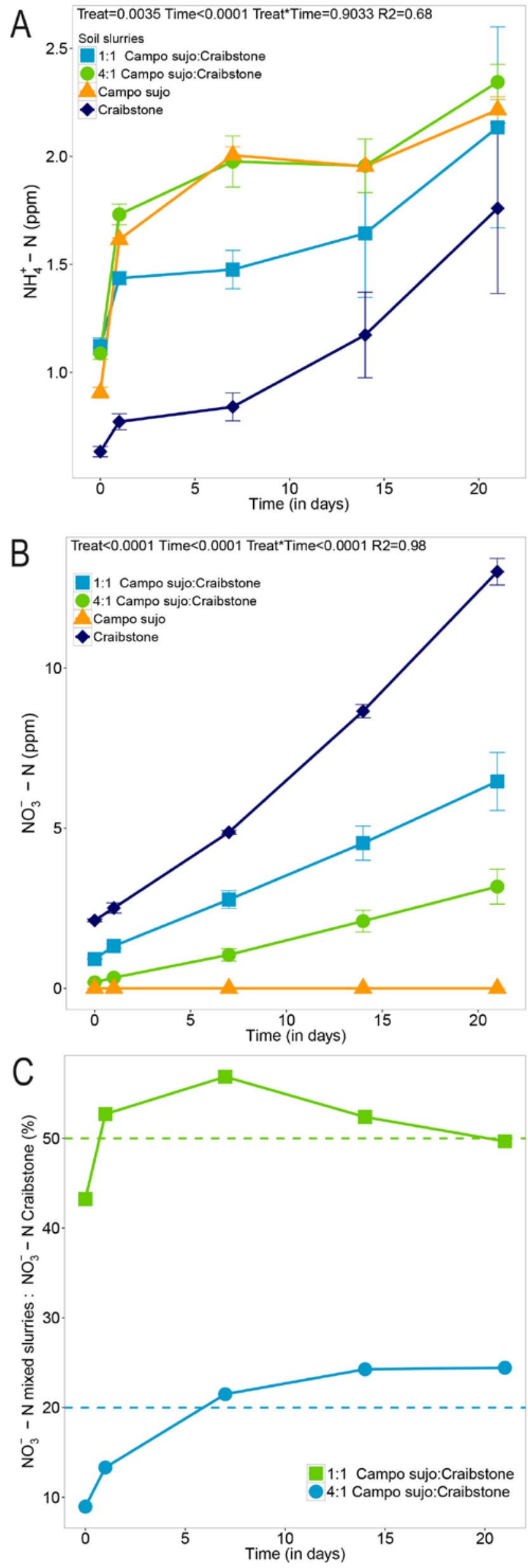
Figure 18. Changes in inorganic $\mathrm{N}$ concentration during incubation of slurries of Craibstone and Campo sujo soils and mixtures of these soils. (A) $\mathrm{NH}_{4}{ }^{+}-\mathrm{N}$ concentration, (B) $\mathrm{NO}_{3}{ }^{-} \mathrm{N}$ and (C) $\mathrm{NO}_{3}$ - concentration in mixed slurries as a percentage of that in Craibstone slurry. Statistical difference is shown by $\mathrm{p}$ value calculated with linear mixed model considering repeated measures (Ime4 package, $R$ version 3.2.3) for each independent variable and their interaction, and the marginal $r^{2}$ associated with the fixed effects. Error bars represent standard errors of the means from triplicate cultures.

There was no evidence for significant changes in ammonia oxidizer amoA abundance, even when significant $\mathrm{NO}_{3}{ }^{-}$accumulation was recorded (Figure 18). AOA amoA abundance in the Campo sujo-only slurries were approximately three orders of magnitude lower than in Craibstone-only slurries (Figure 18A). AOA amoA abundance in mixed slurries was lower than Craibstone-only until 14 days, when we could no longer detect significant difference between AOA amoA abundance between the mixed slurries and the Craibstone. Similarly, $A O B$ abundance in the Campo sujo-only slurries was also approximately three orders of magnitude lower than in Craibstone-only slurries, except after 21 days, when abundance was not significantly different (Figure18B).

$A O B$ amoA gene abundance was lower than $A O A$ in all slurries and the $A O A: A O B$ amoA gene ratio did not change in the Campo sujo-only slurries, in contrast to treatments with Craibstone soil, where the ratio increased (Figure 18C). AOB amoA transcripts were below the level of detection ( 5 copies $\mu^{-1}$ ) in all slurries. AOA amoA transcripts were detected in all slurries containing Craibstone throughout incubation, but were only detected in the Campo sujo-only slurries after incubation for 21 days (Figure 18D). 

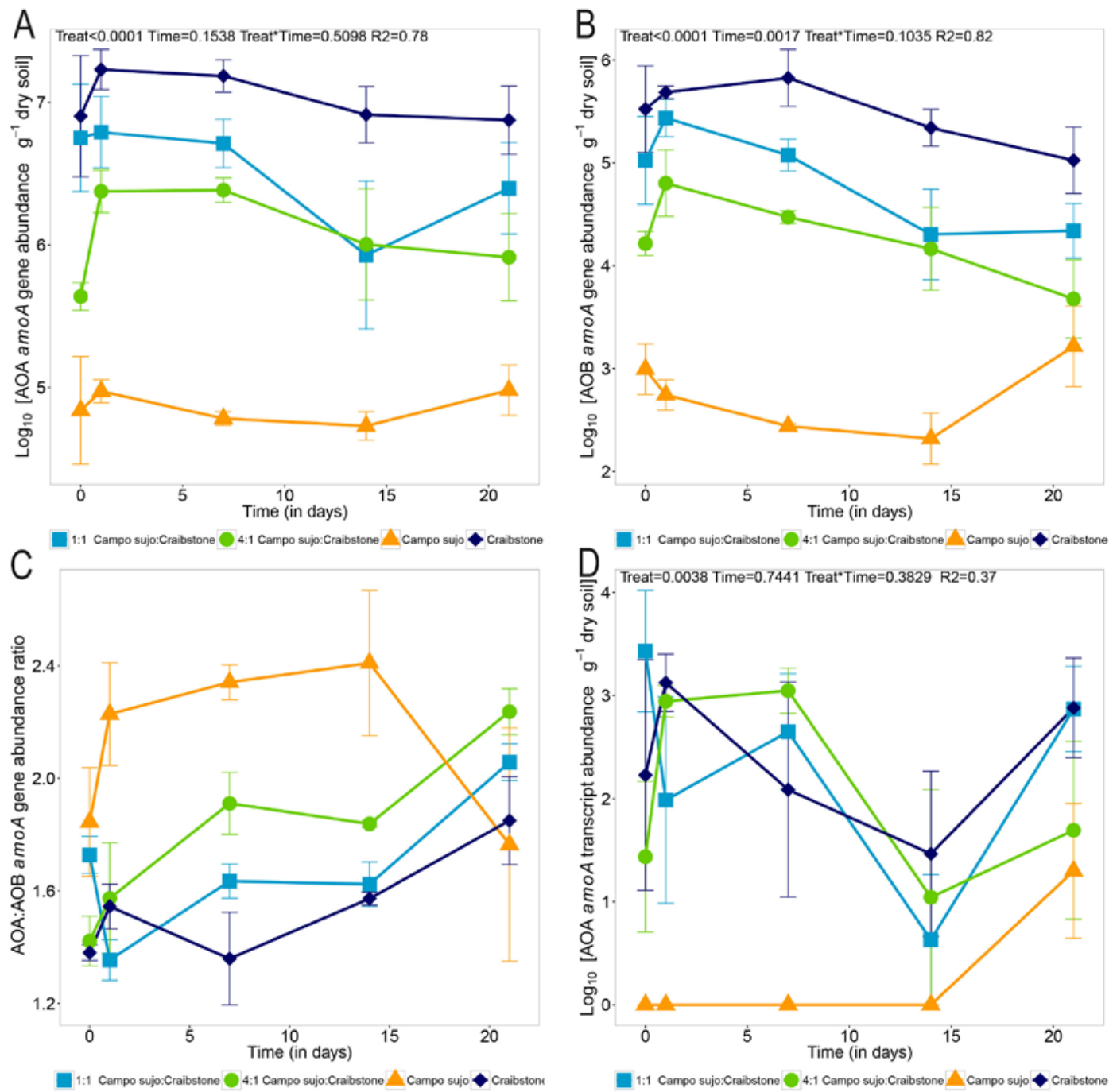

Figure 19. Changes in (A) $A O A$ amoA gene abundance, (B) $A O B$ amoA gene abundance, (C) $A O A: A O B$ amoA gene abundance ratio and (D) AOA amoA transcript abundance during incubation of slurries of Craibstone and Campo sujo soils and mixtures of these soils. Statistical difference is shown by $p$ value calculated with linear mixed model considering repeated measures (Ime4 package, $\mathrm{R}$ version 3.2.3) for each independent variable and their interaction, and the marginal $r^{2}$ associated with the fixed effects

AOA community composition was investigated by DGGE analysis of amoA genes and more DGGE bands were detected in DGGE profiles of Craibstone soil than Campo sujo soil (Figure 19), but will little evidence of changes in the AOA community during incubation. Total AOA community in the mixed slurry 1:1 was very similar to that of Craibstone soil as seen in the DGGE pattern of bands of AOA gene, possibly masking the presence of lower abundance of Campo sujo bands (Figure 19). 


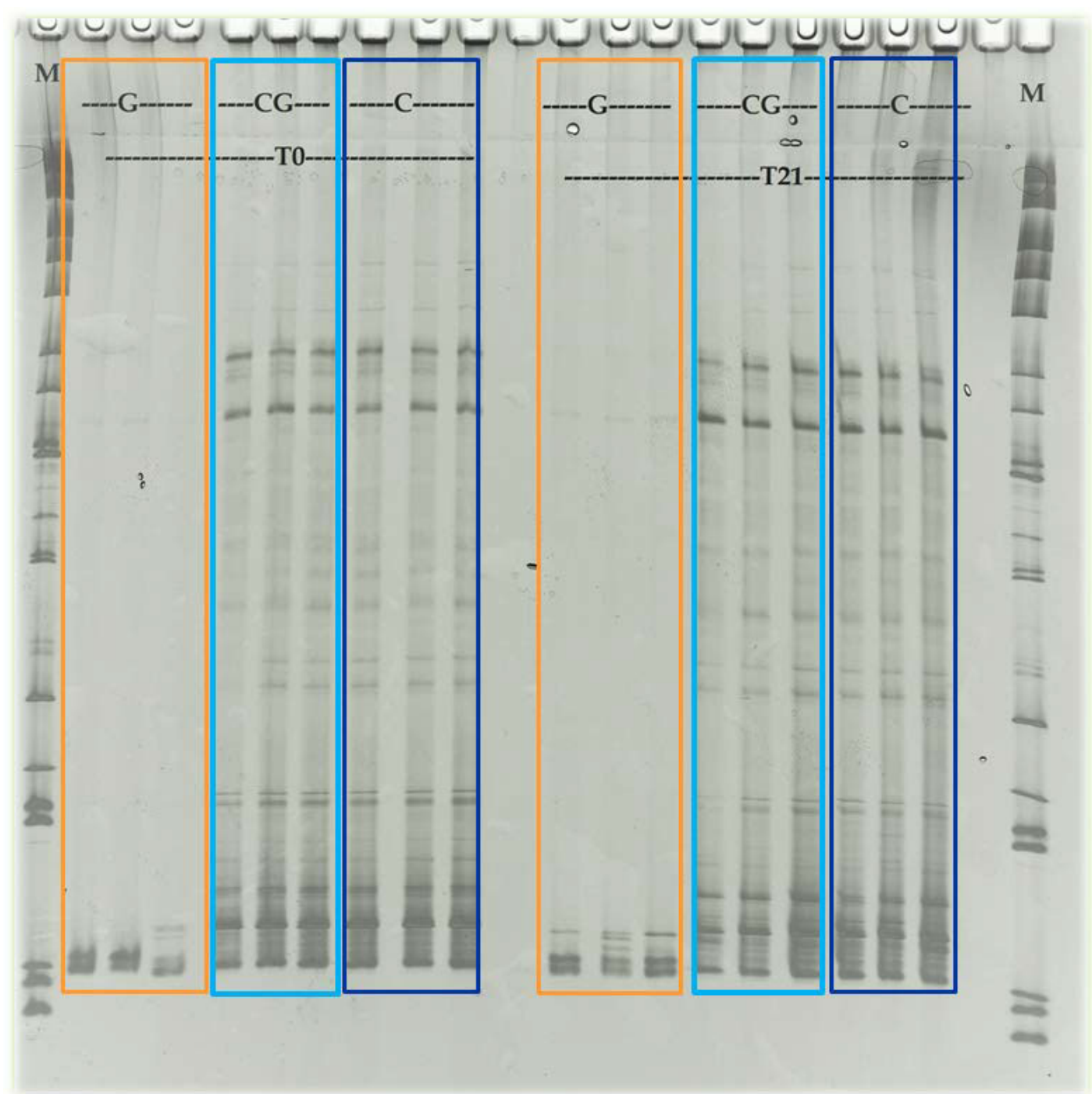

Figure 20. DGGE analysis of partial amoA gene products from triplicate soil slurries of $(G)$ Campo sujo-only, (CG) 1:1 Campo sujo: Craibstone mixed and (C) Craibstone-only sampled after incubation for 0 and 21 days.

\section{Effects of soil $\mathrm{pH}$ and moisture content}

The effects of $\mathrm{pH}$ and moisture content on nitrification in the Campo sujo soil was investigated in soil microcosms. Mineralization in the microcosms was determined by the increase of inorganic $\mathrm{N}\left(\mathrm{NH}_{4}{ }^{+}-\mathrm{N}+\mathrm{NO}_{3}{ }^{-} \mathrm{N}\right)$ concentration over time, assuming that other nitrogen cycle processes were not significant (Figure 20A). Mineralization in the dry soil did not increase after wetting, in contrast to the expected "Birch" effect (Birch, 1964)(Figure 20A). Soil pH did not change significantly with time in the microcosms and remained at 5.2 for 'Water Pulse', 'Moist' and 'Dry' treatments, and 6.3 for the ' $\mathrm{pH}$ ' microcosms in which $\mathrm{pH}$ was increased artificially with $\mathrm{CaCO}_{3}$. There was no evidence of significant increases in 
nitrate concentration in any of the treatments (Figure 20B), with no significant difference between treatments ( $p$ treat $=0.140)$.

Acetylene was used as an inhibitor of ammonia oxidation in half of the samples for all four treatments ('Dry', 'Water Pulse', 'Moist' and ' $\mathrm{pH}$ ') to discriminate $\mathrm{N}$ utilization by soil ammonia oxidizers. No significant difference was observed with and without acetylene, except for the $\mathrm{NO}_{3}{ }^{-} \mathrm{N}$ concentration in the moist microcosms after 21 days. After 21 days, $\mathrm{NO}_{3}^{-}-\mathrm{N}$ concentration was higher in the non-acetylene treated moist microcosms than in those with added acetylene.
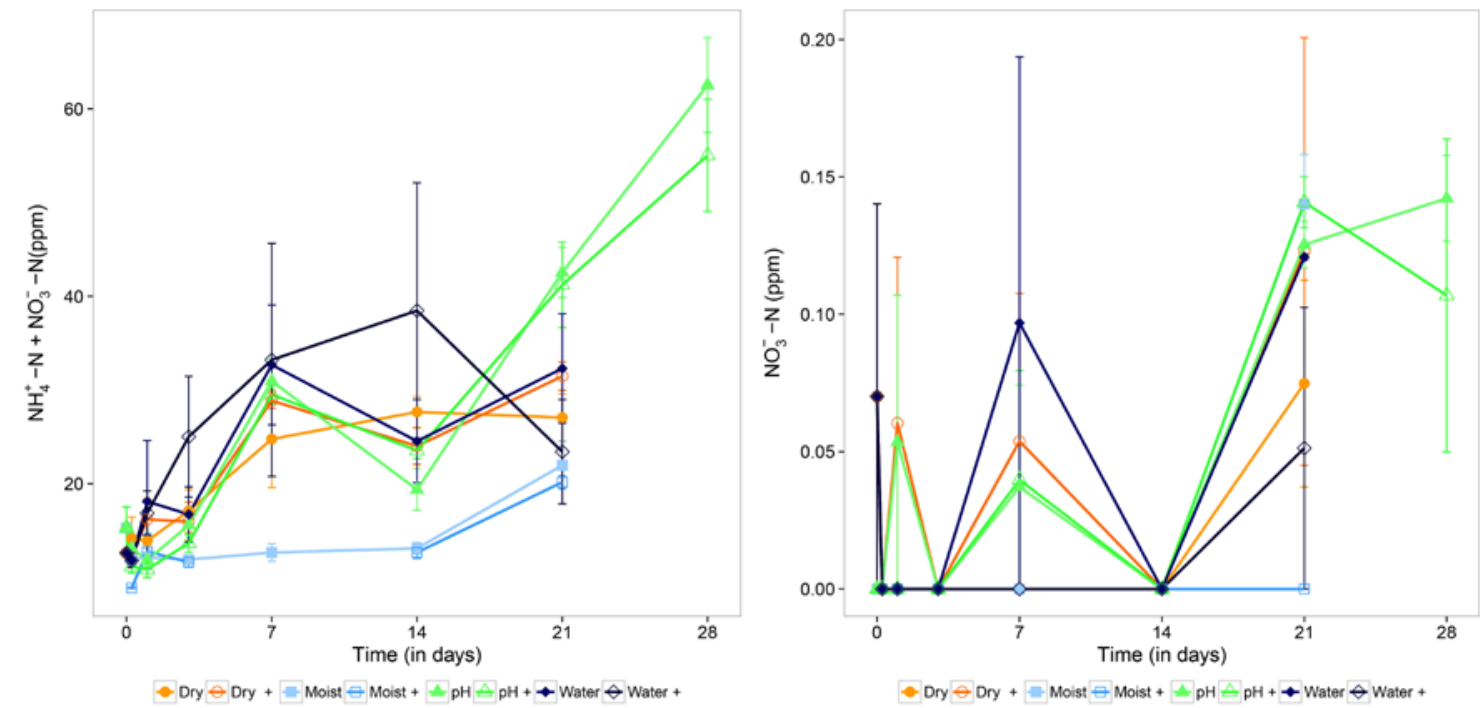

Figure 21. Changes in (A) $\left(\mathrm{NH}_{4}{ }^{+}-\mathrm{N}+\mathrm{NO}_{3}{ }^{-} \mathrm{N}\right)$ and (B) $\mathrm{NO}_{3}{ }^{-} \mathrm{N}$ during incubation of microcosms containing Campo sujo or Craibstone soil after manipulation of $\mathrm{pH}$ and moisture content. Open symbols represent treatments with addition of $0.01 \%$ acetylene in the headspace. Red line represents the threshold limit of detection considered for the FIA technique. Dry: airdried soil to $8.66 \mathrm{~g} \mathrm{H}_{2} \mathrm{O} \mathrm{g}^{-1}$ dry soil; Water: rewetted soil to $39.6 \pm 1.92 \mathrm{~g} \mathrm{H}_{2} \mathrm{O} \mathrm{g}^{-1}$ dry soil; Moist: moist soil; $\mathrm{pH}$ : soil treated with $\mathrm{CaCO}_{3}$ with one $\mathrm{pH}$ unit higher than the other treatments. 


\section{Discussion}

Nitrification is frequently undetectable in undisturbed Cerrado ecosystems, although its management and conversion to agricultural production results in nitrate production (Catão et al., 2016). Previous studies provide evidence for low abundance of AOA and AOB in Campo sujo soil (Catão et al., 2016), which is a shrubland with some sparse shrubs over a continuous grass layer. The aim of this work was to determine whether the lack of nitrification and low abundance of $\mathrm{AO}$ was due to low $\mathrm{pH}$, low soil moisture or $\mathrm{NH}_{4}{ }^{+}$ limitation or biological inhibition of ammonia oxidation.

Certain plants release biological nitrification inhibitors (BNI), that suppress ammonia oxidation in soils (Subbarao et al., 2015), and some, for example produced by Brachiaria (Subbarao et al., 2009) and Sorghum (Zakir et al., 2008), inhibit a recombinant $N$. europaea strain possibly by blocking the ammonia monooxygenase and hydroxylamine oxidoreductase enzymes (Subbarao et al., 2008). Exudation of BNI can be promoted by exposure to high of $\mathrm{NH}_{4}^{+}: \mathrm{NO}_{3}^{-}$ratios (Subbarao et al., 2015), which are found in Campo sujo soil (Catão et al., 2016). There was, however, no evidence for nitrification inhibitors in the Campo sujo soil. Cultures of four $\mathrm{AOB}$ and one $\mathrm{AOA}$, all of which were originally isolated from soil, were not inhibited by aqueous soil, where allylthiourea, a known inhibitor of AOB, prevented nitrification of these organisms, but not that of the AOA culture. This is consistent with other studies that indicate greater tolerance of AOA to allylthiourea (Hatzenpichler and Lebedeva, 2008; Stempfhuber et al., 2015), highlighting the need to testing of potential $\mathrm{BNI}$ and other inhibitors against both $\mathrm{AOA}$ and $\mathrm{AOB}$, rather than $\mathrm{N}$. europaea only.

The above studies suggest the absence of inhibitors within Campo sujo soil, but are based on aqueous soil extracts and a small number of cultivated strains. The potential for soil inhibitory factors was tested more directly by mixing Campo sujo soil with Craibstone soil, a strongly nitrifying soil (Nicol et al., 2008; Zhang et al., 2010) with similar pH, in soil slurries. Soil slurries also provided no evidence of nitrification inhibitors in Campo sujo soil. Nitrate accumulation in soil mixtures was lower than in 'undiluted' Craibstone soil but reductions in mixtures were greater than or equal to those predicted merely through dilution, and not through additional inhibition. There was also no evidence for negative effects of Campo sujo soil on $A O A$ and $A O B$ amoA gene abundances. $A O A$ amoA genes were more abundant than those of bacteria, and no bacterial amoA transcript was detected, as found in previous studies with Craibstone soil (Zhang et al., 2010). Neither AOA nor AOB 
amoA abundance changed significantly during incubation in any of the slurries containing Craibstone soil, despite active nitrate production, but there was evidence for an increase in the $A O A: A O B$ amoA gene ratio, suggesting greater growth, or lower death, of $A O A$. There was no evidence for growth of $A O B$ or $A O A$ in the Campo sujo soil. The low abundance of amoA transcripts in the Campo sujo soil, and smaller number of DGGE bands, compared to Craibstone soil, are further evidence of the low abundance and activity of ammonia oxidizers in the former soil and the absence of detectable ammonia oxidizer activity. Nevertheless, AOA amoA transcripts detection in Campo sujo-only slurries after 21 days suggest that $A O A$ had begun to grow in the Campo sujo soil but that their abundance was not sufficient for them to generate detectable nitrate. Alternatively, undetectable nitrate can reflect the greater variability of amoA community present in the Craibstone-only slurries and the mixed slurries.

Microcosm studies were performed to determine whether low nitrification rates were due to low $\mathrm{pH}$ or low soil moisture content. Soil $\mathrm{pH}$ is considered one of the major factors that influences microbial diversity (Fierer et al., 2012a; Lauber et al., 2009); it has previously been shown to influence soil ammonia oxidizer abundance and activity (de Boer and Kowalchuk, Nicol et al. 2008), with higher transcriptional activity of Archaea than Bacteria as pH decreases (Nicol et al., 2008). An increase in soil pH increased the mineralization rate but did not lead to detectable nitrate production in Campo sujo soil after incubation for 28 days. There was therefore no evidence for limitation of nitrification by low pH. Mineralization was lower in moist soil, but again, the increase in moisture did not lead to detectable nitrate production.

Low nitrification, and low $\mathrm{AO}$ abundance, in both microcosms and slurries was not due to $\mathrm{NH}_{4}{ }^{+}$limitation, as $\mathrm{NH}_{4}{ }^{+}$concentration was even higher than that measured in the Craibstone soil slurries at the beginning of the experiment. Ste-Marie and Paré (Ste-Marie and Paré, 1999) described similar results on a jack pine forest soils that accumulated high concentrations of ammonium but nitrate was not detectable. None of the treatments applied promoted nitrification in Campo sujo soil and no inhibition by this soil on Craibstone or pure culture nitrifiers was observed. In the jack pine forest, nitrification was not stimulated by an increase in $\mathrm{pH}$ or ammonium amendment, but by the addition of nitrifying soil from a forest floor (Ste-Marie and Paré, 1999). In our study, both AOA and AOB were detectable, but at low levels that are unlikely to lead to detectable nitrate production. As a consequent, Cerrado soils have much greater ability to retain $\mathrm{N}$ as $\mathrm{NH}_{4}^{+}$, through ion exchange, and leaching $\mathrm{NO}_{3}{ }^{-}$of nitrate will be low. Our study indicates that low nitrification 
rates and ammonia oxidizer abundance are not due to low moisture content, low $\mathrm{pH}$ or ammonia oxidizer inhibitors within the soil.

Some other process of $\mathrm{NO}_{3}{ }^{-}$use by the microbiota should be considered in further studies, i.e. competition for $\mathrm{NH}_{4}{ }^{+}$by plants or heterotrophic microbes, as described in a Californian grassland (Jackson et al., 1989); dissimilatory reduction of $\mathrm{NO}_{3}{ }^{-}$to $\mathrm{NH}_{4}{ }^{+}$(DNRA) (Chen et al., 2015; Cole and Brown, 1980). 


\section{Chapter 5 - Abiotic and biotic factors that affect ammonia oxidizers and therefore nitrification: final discussion}

“Le savant n'étudie pas la nature parce que cela est utile; il l'étudie parce qu'il y prend plaisir et il y prend plaisir parce qu'elle est belle" Henri Poincaré

\section{0}

years, at least, have passed since $\mathrm{N}$ cycling is the focus of research in the Cerrado biome. Each experiment takes us one step ahead to understand $\mathrm{N}$ conservation in soil ecosystem and the changes that take place in $\mathrm{N}$ utilization by soil fauna, flora and microbiota after natural or artificial disturbances (i.e. fire episodes and agriculture, respectively). The relevance of understanding $\mathrm{N}$ dynamics in the biosphere is both related with how $\mathrm{N}$ limitation controls net primary productivity and the fact that $\mathrm{N}$ cycle is one of the most affected cycles by anthropogenic impact, having crossed the threshold for planetary boundaries (Rockström et al., 2009). Yet, it is a cycle mainly controlled by microbial dynamics, therefore the numerous scientific researches focusing on the association of specific groups of microorganisms and the $\mathrm{N}$ metabolism. 
In the Cerrado, microbial community structure varies according to the types of vegetation (Araujo et al., 2012; Catão et al., 2013; de Castro et al., 2008; Quirino et al., 2009), and to the variations in soil moisture that occurs in Cerrado soils (Catão et al., 2014; Pereira de Castro et al., 2016; Viana et al., 2011). Recently, Pereira de Castro et al. (2016) discussed the general metabolic potential distribution in the Cerrado biome besides the taxonomy approach. Nonetheless, until now no work has focused on the microbial genes associated with $\mathrm{N}$ cycling in the Cerrado.

$\mathrm{NO}_{3}$, the most oxidized form of $\mathrm{N}$, does not accumulate in native Cerrado soils as described in the literature and as found in the three projects developed here (0.03-0.09 $\mu \mathrm{g}$ $\mathrm{NO}_{3}{ }^{-}-\mathrm{N} \mathrm{g}^{-1}$ dry soil). Furthermore, $\mathrm{NO}_{3}{ }^{-}$were low or undetectable in soils sampled from the Campo sujo, contrary to the values obtained in the soil under cultivation of soybean. Net nitrification, obtained as the $\mathrm{NO}_{3}-\mathrm{N}$ over time, was also insignificant in most of the manipulated soils microcosms and slurries, except in the $\mathrm{pH}$ and moist microcosms in which $\mathrm{NO}_{3}{ }^{-}$was detectable after 21 days of incubation. In all of the experiments here performed, $\mathrm{NH}_{4}{ }^{+}: \mathrm{NO}_{3}{ }^{-}$was always greater than 10 , sometimes greater than 50 (as for example in the Cerrado sensu stricto of PNCV, and the Campo sujo in the Farm).

Low net nitrification in the Cerrado biome seems to be related with different biotic and abiotic factors, here described. Soil nutrient dynamics is neither unidirectional nor linear, even though most times the variables have to be considered as such. For instance, $\mathrm{NH}_{3}$ is the substrate for nitrification, but it can be inhibitory in determinate concentrations, especially to AOA that seem to be more sensitive than $A O B$ to ammonia inhibition (Prosser and Nicol, 2012). Therefore, to say that oxidation of ammonia by Bacteria or Archaea is dependent of the soil $\mathrm{pH}$, or the quantity or quality of $\mathrm{N}$ substrate, or moisture, is not informative per se. Especially if we want to understand how soil characteristics' affect the microbial community (or vice-versa), and how we can have better manage the land use with less environmental pollution. This discussion focuses on the results obtained along this thesis and elaborates on the microbial ecology of nitrification, which is resumed in Figure 21.

pH

$\mathrm{pH}$ is within the most cited variables that explains bacterial community distribution in terrestrial ecosystems whether in local scale (Rousk et al., 2010), regional (Bru et al., 2011; Griffiths et al., 2011; Kuramae et al., 2012) or global (Lauber et al., 2009). pH affects microbial cells direct or indirectly and different communities have optimal growth $\mathrm{pH}$, as low $\mathrm{pH}$ seems to be more limiting for bacterial growth than for fungal growth (Bárcenas-Moreno et 
al., 2016). As an example, acidophilic organisms require high protons concentration to keep the integrity of the cytoplasmic membrane, and bacterial communities from acidic soil reach their respiration peak twice later than communities from soil with higher $\mathrm{pH}$ (Bárcenas-Moreno et al., 2016). Nonetheless, bacteria adapted to low pH grow more in higher $\mathrm{pH}$, but bacterial communities transplanted from alkaline soil to acidic one are less successful to grow (Bárcenas-Moreno et al., 2016). As a result, it is not surprising that we find a great correlation between soil $\mathrm{pH}$ and microbial distribution.

Archaeal communities, and more specifically archaeal oxidizers, also present ecological coherence with $\mathrm{pH}$ in soil and can be classified depending on the soil $\mathrm{pH}$ of their greatest occurrence (Gubry-Rangin et al., 2011). AOA predominance over AOB (Leininger et al., 2006) is often associated with low pH soils (Erguder et al., 2009; Gubry-Rangin et al., 2011; Lu et al., 2012; Nicol et al., 2008; Prosser and Nicol, 2012). This was also observed in our data where both fertilization and soybean cultivation decreased the AOA:AOB ratio in association with increases in $\mathrm{pH}$. However, some AOA clusters contribute to nitrification in soils with pH > 5.5 (Gubry-Rangin et al., 2011; Gubry-Rangin et al., 2010), and there is evidence for long-term pH selection of both $\mathrm{AOB}$ and $\mathrm{AOA}$ phylotypes in soil (Nicol et al., 2008; Stephen et al., 1998). As different groups, either between AOA and AOB or within this clades, have different sensibilities to $\mathrm{pH}$ (Stempfhuber et al., 2015) nitrification measurement should be estimated with original soil $\mathrm{pH}$ and not with changed $\mathrm{pH}$ in buffered potential nitrification assays as performed sometimes.

We have observed in situ the change in $\mathrm{NO}_{3}{ }_{-}^{-} \mathrm{N}$ accumulation along the soybean cultivation possibly due to liming and associated with a decrease in the AOA:AOB gene abundance ratio. The field study performed in the farm at Cocalzinho de Goiás (GO) showed a rapid turnover (nearly 4 months) effect of the agricultural practices on the soil microbial community. Whether higher nitrification activity in the soybean soil is due to greater cell growth rates or higher $\mathrm{NH}_{3}$ availability, both related with the greater $\mathrm{pH}$, or if it is a consequence of the NPK solution and urea provided remains to be tested.

Increase in the abundance of ammonia oxidizers associated with increased $\mathrm{pH}$ in the soybean cultivation suggested a pH limitation for ammonia oxidizers growth in the Cerrado soils, which lead to the experiment of $\mathrm{pH}$ change in soil microcosms. The soil from the Campo sujo was mixed with $\mathrm{CaCO}_{3}$ to increase $\mathrm{pH}$ in one unit in microcosms. During incubation it mineralized more inorganic $\mathrm{N}$ than the microcosms incubated with the original $\mathrm{pH}$. Net nitrification increased significantly after 28 days of incubation, but nitrate accumulation was still little $\left(0.14 \pm 0.03 \mu \mathrm{g} \mathrm{NO}{ }^{-}-\mathrm{N} \mathrm{g}^{-1}\right.$ dry soil). We cannot rule out the 
impact of $\mathrm{pH}$ changing the soil microbial community associated with nitrate production in the Campo sujo soil, but modification possibly takes more than 1 month to be significant in laboratory or field assays.

On the other hand, the incubation of the Campo sujo soil in slurries with Craibstone soil of same $\mathrm{pH}$ (original $\mathrm{pH}$ of 5.3) in a ratio 1:1 accumulated nitrate due to the activity of ammonia oxidizers from the Craibstone soil. In 1932, Fraps and Sterges presented similar conclusion that soils with little ability to nitrify has increased nitrate concentration after either soil pH modification with calcium carbonate and/or with the addition of nitrifying soil (Fraps and Sterges, 1932).

Experimental liming in Cerrado parcels lead to a greater differentiation in the microbial community than in the treatments fertilized with $\mathrm{N}, \mathrm{P}$ or $\mathrm{N}+\mathrm{P}$, with a special increase in certain phyla as Gemmatimonadetes (da Silva, 2012). In addition, an increase in $\mathrm{NO}_{3}{ }^{-}-\mathrm{N}$ concentration was observed most likely due to the increase in $\mathrm{pH}$ to 6 (initial $\mathrm{pH}$ was approximatively 4) (da Silva, 2012), which is expected since liming can increase organic matter mineralization a nitrification in soils (Rosolem et al., 2003). Nevertheless, liming was performed in those areas for years which differs from our study in the microcosms that lasted only 1 month.

\section{$\mathrm{NH}_{4}{ }^{+}$}

Furthermore, cells need to be adapted to the availability of nutrients in lower $\mathrm{pH}$. $\mathrm{NH}_{3}$ instead of $\mathrm{NH}_{4}{ }^{+}$is assumed to be the substrate for ammonia oxidation (Suzuki et al., 1974) as $\mathrm{NH}_{3}$ diffuses passively but $\mathrm{NH}_{4}{ }^{+}$needs active transport inside the cell, which leaded to the hypothesis that intracellular urea hydrolysis facilitates autotrophic ammonia oxidation in low pH soil and $\mathrm{NH}_{4}{ }^{+}$produced in excess can locally increase $\mathrm{pH}$ (Burton and Prosser, 2001).

High $\mathrm{NH}_{4}{ }^{+}$concentration was considered to be toxic to AOA especially, which seemed to be more sensitive to $\mathrm{NH}_{4}{ }^{+}$concentration than $\mathrm{AOB}$ (Verhamme et al., 2011), and AOA were found in higher abundance in the Campo sujo (Catão et al., 2016) soil as expected due to the low pH (Prosser and Nicol, 2012). As the undisturbed Campo sujo soil had the highest net $\mathrm{N}$ mineralization rate (average of $2 \mu \mathrm{g} \mathrm{NH}_{4}{ }^{+}-\mathrm{N} \mathrm{g}^{-1}$ dry soil day ${ }^{-1}$ ) and the lowest net nitrification rate, an inhibition of nitrification or low abundance of nitrifiers despite the presence of $\mathrm{NH}_{4}{ }^{+} \mathrm{N}$ had to be considered. However, inhibition by $\mathrm{NH}_{4}{ }^{+}$concentration was also ruled out as ammonia oxidizers community from Craibstone was also represented by more $A O A$ than $A O B$ gene abundance and activity and was stimulated by the $\mathrm{NH}_{4}{ }^{+}$ 
concentration with increased nitrification with time. Others have found similar result were $\mathrm{NH}_{4}+$ availability did not constrain net nitrification (Nugroho et al., 2007).

\section{Heterotrophic nitrification}

Substrate is one of the determinants for the predomination in $A O A$ or $A O B$ in terms of ammonia oxidation: AOA dominate soils in which ammonia is available from organic $\mathrm{N}$ (Levičnik-Höfferle et al., 2012) and in lower concentrations (Prosser and Nicol, 2012). The balance between autotrophic and heterotrophic nitrification seems also to be regulated by the substrate source in certain soils (Zhang et al., 2014). Poth et al (1995) detected the NO formation related to hetetrotrophic nitrifiers in Cerrado (Poth et al., 1995).

In addition, $\mathrm{C}$ substrate, or as often cited, the C:N ratio, influences the nitrogen cycling. In less than 4 months we could observe a change in the $\mathrm{N}$ dynamic of the soybean cultivation area with slight increase in $\delta 15 \mathrm{~N}$ and nitrification rate and significant increase in the abundance of ammonia oxidizers. Soil gross $\mathrm{N}$ transformation was modified in a conversion from woodland to tea plantation in an acidic oxisol, measured in lands where plantation was established after 1,5 or 30 years; $\mathrm{NO}_{3}^{-}-\mathrm{N}$ production by nitrification and $\mathrm{N}_{2} \mathrm{O}$ increased and $\mathrm{NO}_{3}{ }^{-}-\mathrm{N}$ immobilization decreased according to the time after conversion. In addition, under the woodland, nitrification was mostly heterotrophic, contrary to both autotrophic and heterotrophic nitrification in the tea plantation soil as measured by ${ }^{15} \mathrm{~N}$ trace experiment (Zhu et al., 2014). Finally, nitrification in Cerrado soils might be performed by heterotrophic organisms also able to denitrify so nitrate does not accumulate (Kuenen and Robertson, 1994).

In the microcosms experiment, the $\mathrm{pH}$-changed treatments had no significant difference between acetylene treated and non-acetylene microcosms, which might suggest that the observed increase in $\mathrm{NO}_{3}^{-}-\mathrm{N}$ was a result of heterotrophic nitrification. Furthermore, there is evidence that the amoA community present in the Cerrado soils is not performing ammonia oxidation. Thaumarchaeota are often related to $\mathrm{N}$ metabolism in soil, but the 1.1c cluster is abundant in soil but not related to ammonia oxidation (Weber et al., 2015). The higher ratio of thaumarchaeal 16S rRNA:archaeal amoA found in the undisturbed soil than in the soybean field is an indicative that a greater part of the archaeal community in these soils might be from $1.1 \mathrm{c}$ cluster. 


\section{Inhibition of nitrification}

Nitrification is the main focus of this work and many others, however mineralization is the first step to be consider as it is responsible for the release of inorganic N (SCHIMEL). As fungal/bacterial abundance ratio increases in lower pH (Bárcenas-Moreno et al., 2016), fungi might have higher effect on organic matter mineralization in acidic soils. The low abundance of ammonia oxidizers in Cerrado soils may be due to competition with soil fungi for ammonium or inhibition by bioactive compounds synthesized by fungi (Suzuki et al., 1974).

In addition, some plants produce inhibitors of nitrification that preserve $\mathrm{N}$ in $\mathrm{NH}_{4}+$ form in the soil (Kölln et al., 2016), named biological inhibition (BNI) promoted by plants (Subbarao et al., 2015) (Subbarao et al., 2009) (Zakir et al., 2008). Root extracts from plants used in agriculture (S. spontaneum, species that forms sugarcane hybrids cultivated) or pasture (B. humidicola) (Kölln et al., 2016) or soils cultivated with brachiarias (Fernandes et al., 2011) (Subbarao et al., 2009) in Cerrado biome decrease $\mathrm{NO}_{3}^{-}$accumulation in soil, but less than the inhibitory effect of DCD.

Another example is the selection of specific subset of the soil bulk microbial community, which appears to be related to growth promotion and nutrition, in soybean rhizosphere (Mao et al., 2011; Mendes et al., 2014). Albeit possible for Cerrado native plants, this has not been demonstrated yet and neither soil solution from native Campo sujo nor soil sampled at same $\mathrm{pH}$ in nitrifying Craibstone station, did not inhibit AOA or AOB pure cultures. The activation of BNI synthesis depends on the exposition to a higher concentration of $\mathrm{NH}_{4}^{+}$than $\mathrm{NO}_{3}^{-}$(Subbarao et al., 2015), which is the case of the Campo sujo soil here studied. Despite that, the general assumption of low nitrifiers abundance in bulk soil, and the potential ability of hydrophilic BNIs to diffuse in soil, it is still possible that BNIs are only relevant in the rhizosphere and for the microbial community present in this microhabitat. However, bulk soil from Campo sujo just did not inhibit as it stimulated ammonia oxidation from organisms from the Craibstone soil in slurries. In addition, the detection of $A O A$ amoA transcript increased after the 21 days in the Campo sujo, indication of activity in the $\mathrm{AOA}$ community despite undetectable $\mathrm{NO}_{3}$.

$\mathrm{Fe}$

Moreover, inhibition does not need to be biotic. For example, $\mathrm{NO}_{3}^{-}$can be immobilized biotically and abiotically. The adsorption of $\mathrm{NO}_{3}^{-}-\mathrm{N}$ to free Fe oxide might to be 
considered; especially as Fe concentration was high in the Cerrado soils sampled in this study. In temperate forest soils, abiotic immobilization of ${ }^{15} \mathrm{NO}_{3}{ }^{-}$to the $\mathrm{DO}^{15} \mathrm{~N}$ occurs within minutes (Dail et al., 2001) and is independent of soil $\mathrm{N}$ status, contrary to the negative correlation observed between microbial $\mathrm{N}$ immobilization and soil $\mathrm{N}$ concentration (Johnson et al., 2000). Net nitrification in subtropical acid soils was also significantly inhibited by Fe oxide addition in the form of hematite in cambisols, and $A O A$ and $A O B$ gene abundance decreased (Jiang et al., 2015). Total Fe concentration in the Cerrado soils studied (ranged from 46 to $375 \mathrm{mg} \mathrm{dm}^{-3}$ ) here were higher than the values mentioned by Jiang et al. (2015) for the subtropical ferralsols with high $\mathrm{NO}_{3}{ }^{-}$immobilization and low net nitrification, supporting the hypothesis that abiotic $\mathrm{NO}_{3}{ }^{-}$immobilization takes place in soils from the Cerrado. The mechanism involves reduction of nitrate to nitrite catalyzed by Fe(II) minerals in soil, that being more reactive, reacts with DOC, producing DON which would be available to heterotrophic use (Davidson et al., 2003). The model proposed by Zhu et al. considers the increase of the abiotic adsorption of $\mathrm{NO}_{3}{ }^{-} \mathrm{N}$ in tea plantation than in the woodland control to be related with the higher concentration of Fe oxides measured in the soil under tea plantation (Zhu et al., 2014).

Yet, the low abundance of ammonia oxidizers observed in the Cerrado soils is congruent with the low values of nitrate obtained and the hypothesis of $\mathrm{N}$ retention in those soils. Nonetheless, the possible interference of Fe in the accurate measurement of $\mathrm{NO}_{3}{ }^{-}$concentration is debatable (Colman et al., 2008; Davidson et al., 2008), and different methods (Yang et al., 2012) should be further tested with the Cerrado soil. Abiotic retention of nitrate should be considered, but is not the only explanation, as the observed increase nitrification in the soybean cultivation soils occurred despite the permanence of measurable levels of Fe in these soils. In this case, the Fe oxidation state in soil should be evaluated as well.

\section{Soil texture and water contents}

Another variable to be considered is microbial substrate, as microorganisms are not planktonic in soil, and are most likely protected from $\mathrm{pH}$ fluctuations in soil, as suggested in culture with added vermiculite (Allison and Prosser, 1993). Furthermore, clay particles and the presence of charcoal shaped the bacterial community structure, which stablished in a non-stochastic manner, as shown for the inoculation of artificial soils with different mineral composition (Ding et al., 2013). Similarly, nitrification was stimulated by increasing soil 
particle surface due to higher abundance and activity of both $A O A$ and $A O B$ in an acidic soil (Jiang et al., 2011).

Nowadays, researchers are aware of the need to consider microhabitats between soil particles to understand the microbial response to disturbances in micro-scale (Vos et al., 2013). Soil texture influences the size of pores, water capacity, and soil particles charge. Potentially this affects the microbial community, as found for the Cerrado conservation parks that presented higher a-diversity in sandy soils, therefore lower pore connectivity and lower competition between cells or for substrate (Carson et al., 2010). Fine particles allow for a greater colonization because of greater surface area as showed for the addition of pure culture of Nitrosomonas europaea with ammonia-treated vermiculite (Armstrong and Prosser, 1988). Ammonia oxidation occurs preferentially at the surface of vermiculite, but not all ammonia is used by the bacteria possibly because of ammonium adsorption to the clay particles (Armstrong and Prosser, 1988).

Soil texture is directly correlated with water soil capacity, soil minerals and metals. Such that Cerrado rupestre was the driest soil sampled, and the soil with greatest composition of sand. The two conservation parks differ mainly in soil texture, varying from loamy sand (CR in PNCV) to clay (CD in PESA). Most of them were classified as sandy clay loam (PNCV: MG, SS; PESA: MG, SS, FSD). The soils in PESA have higher clay content than those in PNCV, even though there was a significant difference in soil texture within the samples in PNCV. Nevertheless, in all of them, the phyla Proteobacteria, Actinobacteria and Firmicutes were the most abundant.

Furthermore, water availability is considered one of the main drivers of the vegetation gradient in the Cerrado (Bustamante et al., 2006), and of microbial distribution, which is reasonable if we consider that microbes are confined to a thin layer of water in the soil particles, and that water limits prokaryotic life in soil (Fenchel, 2012). This was observed in the metagenomes, as Campo limpo, the vegetation type with greatest soil water content, had significantly more genes annotated for motility and chemotaxis than the other soils in PNCV ( $p<0.0001)$. Campo limpo had also a significant higher frequency of genes annotated for nitrogen fixation, in accordance with the high abundance of sequences from the order Rhizobiales (more than $50 \%$ of bacterial sequences, $\mathrm{p}=0.048$ ), mainly represented by Bradyrhizobiaceae. Even though $\mathrm{N}$ fixation is often correlated with symbiotic interactions, which are major for plant nutrition, in the Campo limpo, the microorganisms performing $\mathrm{N}$ fixation are most likely free-living. 
Considering the relevance of water in Cerrado terrestrial ecosystems and the effect of rainfall on soil microbial communities (Bresolin et al., 2010; Mendes et al., 2012; Pinto et al., 2006; Viana et al., 2011), and that soil moisture may explain potential nitrification rate with the soil water content more than pH (Stempfhuber et al., 2015), an experiment was designed to test the effect of soil moisture on nitrification in a Cerrado Campo sujo soil. For instance, in a Chilean semiarid soil and in the seasonally dry Californian grassland, water addition promoted a change in the community of ammonia oxidizers and increased nitrification (Bustamante et al., 2012a; Placella and Firestone, 2013). Initially, Campo sujo soil was air-dried to $8 \%$ soil water content, which is a value previously described as normal during dry season in the Cerrado soils, and was also found in the Cerrado rupestre in PNCV. It was assumed that by increasing soil water content to $40 \%$ with or without previously airdrying the soil, solute transportation or cell mobility would facilitate ammonium availability for ammonia oxidizers. Furthermore, the water addition after drying the soil would lead to a birch effect (Birch, 1964) with higher $\mathrm{N}$ mineralization, therefore providing substrate for AOA especially known to prefer inorganic forms of N (Prosser and Nicol, 2012). However, we could not detect the expected effect of soil moisture over nitrate production. $\mathrm{NO}_{3}^{-}{ }^{-} \mathrm{N}$ was only detected after 21 days, indicating once more that the time of experiment might have been short to promote a change in the community.

As mentioned before, Cerrado has annual draught during winter and the beginning of the rainy season, and also the addition of water experimentally, promotes an increase on microbial biomass (da Silva, 2004; Nardoto and Bustamante, 2003), microbial activity and nitrification rates (da Silva, 2004), change the bacterial composition with the transition of dry season to the rainy (Bresolin et al., 2010; Nardoto and Bustamante, 2003; Pinto et al., 2006). Generally, low emissions of $\mathrm{NO}$ and $\mathrm{N}_{2} \mathrm{O}$ are associated with soils in which $\mathrm{NH}_{4}{ }^{+}$is the dominant form of inorganic $\mathrm{N}$ and the pool size can be a good indicator of whether the system is open to nitrate leaking or conserves $N$ in ammonia (Davidson et al., 2000). Litterfall C:N ratio also reflects $\mathrm{N}$ availability and consequently predicts $\mathrm{NO}$ and $\mathrm{N}_{2} \mathrm{O}$ emissions from soils (Davidson et al., 2000). Davidson et al (1990) suggested that in low N availability soils, nitrifying bacteria starve and low population capacity is associated with low nitrification potential (Davidson et al., 1990).

Heil et al (2015) highlighted the relevance of considering the coupling between abiotic and biotic reactions (Heil et al., 2015). For example, the delay between ammonia and nitrite oxidizers recovery after rewetting a dry soil can possibly allow for $\mathrm{NO}_{2}^{-}$accumulation (Gelfand and Yakir, 2008), otherwise unusual as ammonia oxidation is considered the rate- 
limiting step of nitrification. Consequently, higher $\mathrm{NO}_{2}^{-}$concentration after the first rain leads to pulses of nitrogen trace gases emissions, as HONO and NO can be abiotically selfdecomposed from $\mathrm{NO}_{2}^{-}$(Su et al., 2011) or directly produced by AOB (Oswald et al., 2013). In the microcosm experiments, conclusions for little influence of soil moisture on nitrification were taken from the undetectable concentration of $\mathrm{NO}_{x}$ (data not shown). However, if the recovery rate of nitrite oxidizers is delayed, follow-up experiments should measure nitrite specifically and amoA transcripts, which was not possible with the soil used in the microcosms as RNA recovery was not efficient with the methodology used. Special attention should be payed to AOA amoA as NO may be an intermediate in the archaeal ammonia oxidation pathway (Stahl and de la Torre, 2012), and as studies with gases show an increase in NO emission after water addition (Pinto et al., 2002), otherwise $\mathrm{NO}$ and N2O emission are near limit of detection and lower than the observed in Amazon sites (Verchot et al., 1999).

Most likely the low $\mathrm{NO}$ and undetectable $\mathrm{N}_{2} \mathrm{O}$ emissions are related with the low levels of $\mathrm{NO}_{3}$ - and nitrification in Cerrado soils, as well as with the high $\mathrm{NH}_{4}{ }^{+}-\mathrm{N}^{-} \mathrm{NO}_{3}{ }^{-} \mathrm{N}$ ratio found. Nonetheless, the $\mathrm{N}$ gases emissions are expected to increase after land use change (Weitz et al., 1998). N conservation in a Namibian savanna soil was also correlated with the low availability of $\mathrm{N}$ for nitrification and denitrification; and the use of low amounts of fertilizers did not increase significantly the $\mathrm{N}_{2} \mathrm{O}$ emissions when compared to the native savanna (Braker et al., 2015). Nevertheless, the conversion of land use and the increased availability of $\mathrm{C}$ is expected to change denitrification in these soils, as low $\mathrm{N}_{2} \mathrm{O}$ emission was associated with low organic matter beside soil drainage and low nutrient levels (Castaldi et al., 2006).

Increase in soil moisture is associated with increased $\mathrm{N}$ loss either with $\mathrm{NO}_{3}^{-}$leaching or runoff after a rainfall or by emission of $\mathrm{N}$ gases during denitrification. Consequently, the regulation of $\mathrm{NO}$ or $\mathrm{N}_{2} \mathrm{O}$ emission are genetic, ultimately, as it depends on the abundance of microbial guilds for nitrification and/or denitrification. Modular reactions characterize denitrification and can be performed by different organisms (Graf et al., 2014). These might contain genes for the reduction of nitrite, nitric oxide and nitrous oxide, or just one of the above (Graf et al., 2014). Therefore, the greater relative abundance of nosZ gene, especially of clade II, the greater sink capacity for $\mathrm{N} 2 \mathrm{O}$ (Jones et al., 2014). This trait is a polyphyletic characteristic, found in Bacteria, Archaea, and Fungi. Most of the organisms capable of reducing nitrate and nitrite are heterotrophic aerobic able to live in anaerobic environments. Although Cerrado soils are well-drained these organisms may be able to 
denitrify in semiarid soils (McLain and Martens, 2006) (Braker et al., 2015). In addition, McLain and Martens (2006) highlight the relevance of heterotrophic nitrificationdenitrification in $\mathrm{N} 2 \mathrm{O}$ emission by fungi in semiarid soils (McLain and Martens, 2006).

\section{Cerrado vegetation cover and land use change}

The Cerrado is composed by a gradient of trees/shrubs layer ranging from grasslands to forests and savannas. Both analysis of phospholipid fatty acids and 16S rRNA genes have showed that this vegetation cover influences the soil microbial composition (Araujo et al., 2012; Mendes et al., 2012; Viana et al., 2011). However, agriculture and managed pasture for cattle breeding changed Cerrado landscape in approximately 53\% (Beuchle et al., 2015), with increasing alterations in floristic composition and edaphic characteristics due to fertilization, liming, and crop monoculture itself.

Soil management and monoculture crops are associated with a decrease in total and microbial N (Hernández-Hernández and López-Hernández, 2002; Peixoto et al., 2010; Vinhal-Freitas et al., 2012) (Bresolin et al., 2010; Paula et al., 2014). Land use change can alter soil sink (or source) capacity for $\mathrm{N}$ gas emissions, which can be produced during nitrification and denitrification. In view of the economic and ecological costs of fertilization and $\mathrm{N}$ losses, it is important to investigate nitrifiers in Cerrado soils to develop better soil management practices.

We showed the short-term modification on $A O A$ and $A O B$ abundance along a soybean culture. The change in the abundance of ammonia oxidizers was associated with the increase in $\mathrm{pH}$, but in turn, the soil $\mathrm{pH}$ decreases the availability of $\mathrm{Al}^{+3}$ and other cations, and as we have described above, the presence of Fe in soil can alter its capacity of $\mathrm{NO}_{3}{ }^{-}$absorption.

Not only we can see that $\mathrm{N}$ dynamic changes according to several soil biotic or abiotic variables, the change in the microbial community is related with the input and output of $\mathrm{N}$ forms in soil. Mostly, the input of fertilizers in agriculture, aimed at a higher plant productivity, promote a shift in the microorganisms performing mineralization, nitrification and other processes, and leads to higher nitrate leaching and $\mathrm{N}$ gases emission. None of this is new, but clearly more changes towards a more sustainable agriculture is needed, as no one expects agriculture to stop growing, but to be more effective. Moreover, there is a debate in the use of microorganisms as indicators of soil quality (Mendes et al., 2016). 
Although the work in the present thesis was performed only in one type of soil in a farm land area in recovery from gravel, native soil was sampled in two other areas and showed similar patterns of low nitrate accumulation and potentially low abundance of ammonia oxidizers. Therefore, it is reasonable to assume that similar changes can take place in other areas of Cerrado. The impact of soil history on the microbial community was evaluated in the Cerrado: even after 17 years of succession from recovery of agricultural use the microbial community was still more similar to that present in the soil under a monoculture community than the one found in an adjacent native area (Rosolem et al., 2003).

Considering the above, it is suggested that microbial phylogenetic and/or functional potential diversity should be considered in models. As an example, microbial stoichiometry is more and more considered in models of carbon or other nutrients cycling. For example, the lower microbial carbon use efficiency (the fraction of assimilated $C$ used for growth rather respiration) is related with higher C:N (more recalcitrant) plant inputs (Averill et al., 2014). In addition, it was suggested that microbial N:P ratios, better than those from plants, can help the assessment of nutrient limitation in terrestrial ecosystems, at least in the tropical rain forest P-limited in Costa Rica (Cleveland and Liptzin, 2007).

On the other hand, Graham et al. found that models on edaphic parameters were not improved by data on microbial gene abundance, but they also criticized that they might have missed environmental factors that better explain microbial community structuring. Furthermore, they suggest the inclusion of temporal dynamics in models to understand edaphic factors and microbial communities on the ecosystem functioning (Graham et al., 2014).

\section{Final considerations and new hypotheses}

Metagenomic studies have been of great importance to show the potential diversity of an environment, however it has a tendency of amplifying the most abundant microorganisms in the sample, which justifies the fact that $97 \%$ of the annotated genes are bacterial. This is also related with the fact that only 2 genes were annotated as ammonia monooxygenase in the metagenomes, as $\mathrm{QPCR}$ analysis showed AOA and AOB abundances between $10^{3}$ to $10^{5}$ maximum, most likely under the threshold of capturing with the coverage used with 454 sequencing. Considering the higher number observed of AOA in the Campo sujo $\left(10^{5}\right)$, and that microorganisms occupy $5 \%$ of the soils pore space, and 
considering a density of $1.2 \mathrm{~g} / \mathrm{dm}^{3}$ for the Cerrado's soil, we find that microbial cells occupy $10^{+15} \mu \mathrm{m}^{3}$ of pore space. The average cell size is $0.6 \mu \mathrm{m}^{3}$, therefore there are around 67 millions of microorganisms in $1 \mathrm{~g}$ of Cerrado soil, which is accordance to previous cultureindependent descriptions (Roesch et al., 2007). According to this there is $1 \mathrm{amoA}$ of Archaea per $10^{7}$ cells, approximately. Comparing our findings with other metagenomes available (IDs 4477751.3-4478937.3 (Mendes et al., 2014), IDs 4578924.3-4578926.3, 4577669.3-4577672.3, 4578714.3 (Souza et al., 2016), project “Biodiversidade microbiana do bioma caatinga” (Lopes et al., 2016), IDs 4485218.3-4485219.3, IDs 4493544.3-4493893.3 (Navarrete et al., 2015)) in the MG-Rast platform there is an average of 1 copy of ammonia monooxygenase per 100 thousand sequences, independent of the sequencing methodology or the sample. Although there were samples that presented higher abundance as for example the environmental samples from the Paraguaçu river (Lopes et al., 2016).

On the other hand, this is the first assessment of the $\mathrm{N}$ metabolism in the Cerrado with metagenomic data, and these data might help understand the impact of land use change on soil microbiota on this Brazilian savanna and consequently in the ecological processes by them produced. Although metagenomics allowed a holistic assessment of the $\mathrm{N}$ cycling in this study, low abundance genes are ignored and the valuation of relative abundance of processes had to be carefully discussed. The direct amplicon sequencing or the measurement of abundance of specific genes by $\mathrm{QPCR}$ are more advised in studies aiming at the balance of microbial community due to biotic or abiotic disturbance. Although a recent study highlighted the relevance of metagenomic and single-cell techniques to tackle the unclassified sequences obtained with amplicon due to primer bias (Eloe-Fadrosh et al., 2016). In addition, when working with databases one should be aware of where to look for the genes, as we found the amo genes classified as membrane transporters and not in the list of genes for the subsystems of $\mathrm{N}$ metabolism. This is reasonable since the gene amoA used to quantify the abundance of ammonia oxidizers codes for the membranebound $\mathrm{AMO}$ enzyme, that takes $\mathrm{NH}_{3}$ rather than $\mathrm{NH}_{4}{ }^{+}$as a substrate.

The little accumulation of nitrate in the treated microcosms or in the slurries, and the absence of the inhibition effect observed in slurries and pure cultures suggests that some other mechanism occurs in this ecosystem to preserve inorganic $\mathrm{N}$ preferentially in the $\mathrm{NH}_{3}$ form. It is likely that not only the presence of ammonia oxidizers is fundamental for nitrification to occur, but that the microbial community composition and diversity affects the direction in which $\mathrm{N}$ process occur in soil, as showed by the higher number of bands in the DGGE analysis in the Craibstone AOA community than in the Campo sujo soil. As 
"narrow processes" have additive functionality (Levine et al., 2011), the lower number of bands of amoA gene detected in the Campo sujo soil can be related with the lower nitrification activity. On the other hand, we could not detect the expected effect of soil moisture over $\mathrm{NO}_{3}$ production, indicating once more that the time of experiment might have been short to promote a change in the community.

Most likely there is a relation between abiotic and biotic conditions that limits the microbial community to low abundance of autotropic ammonia oxidizers possibly towards an ecosystem $\mathrm{N}$ conservation. Figure 21 repeats the basic $\mathrm{N}$ cycle that occurs in terrestrial ecosystems (annanmox was excluded) presented in Figure 1 and includes now the influences evaluated in this work and/or considered in the discussion.

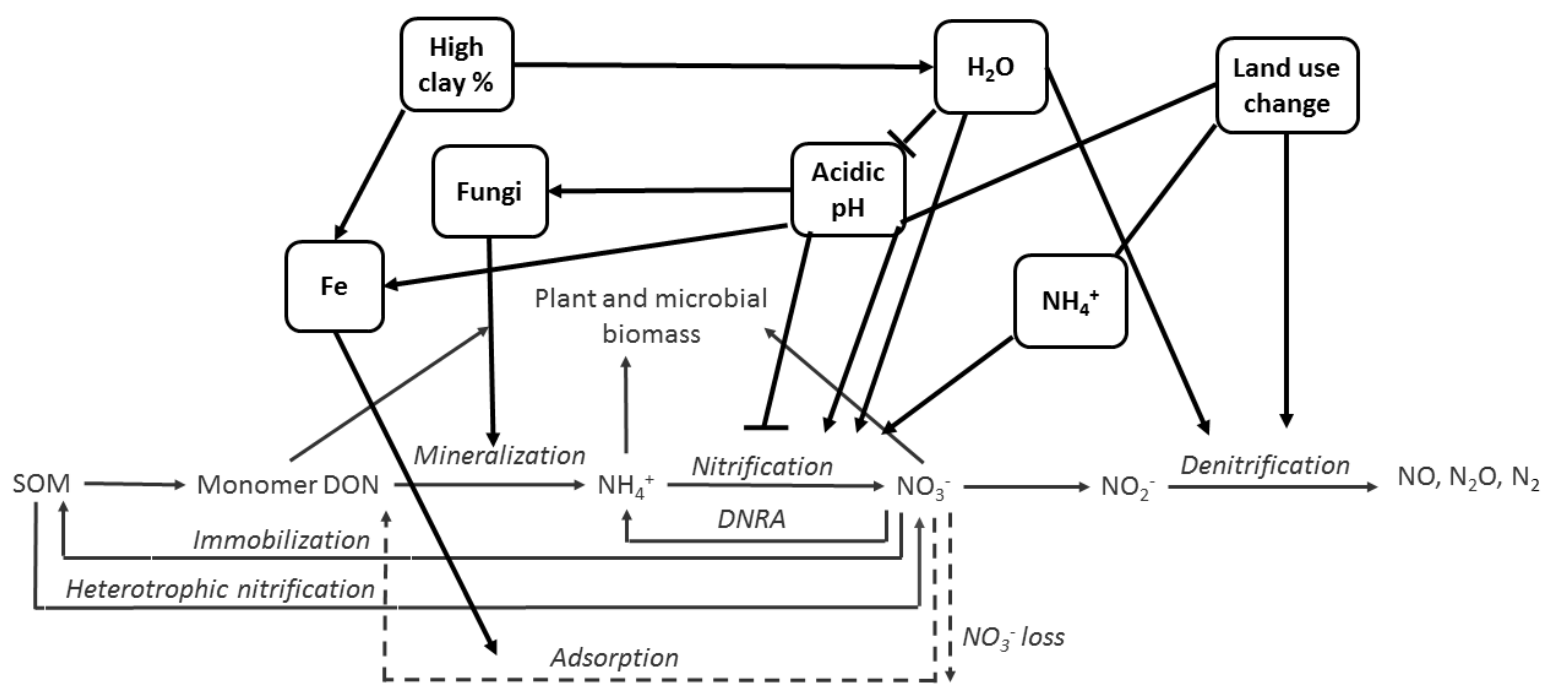

Figure 22. Interaction between abiotic and biotic factors and their effect on the $\mathrm{N}$ cycle processes

Others have showed environmental factors that affect ammonia oxidation (Erguder et al., 2009). In this study we observed that tillage, fertilization, liming, and soybean monoculture altered soil $\mathrm{pH}$, moisture, and inorganic $\mathrm{N}$ contents, all of which can influence the abundance and diversity of microbial communities and their functional potential, thereby influencing the production of $\mathrm{NO}_{3}{ }^{-}, \mathrm{NO}_{2}{ }^{-}, \mathrm{NO}$, and $\mathrm{N}_{2} \mathrm{O}$ (Mao et al., 2011). The change after fertilization and liming illustrates the prevalence of determinate species in nutrient utilization, and highlights the shift in the community related with the nutrient dynamic, loss and conservation. 
Moreover, microbial ecology research needs to consider microbial cells physiology as different organisms have knowingly diverse growth rates and to not observe increase in abundance or growth of an organism does not mean necessarily that this one is not active, but that something is limiting its growth; limitation that can be either biotic or abiotic as exposed above. Allison and Prosser (1993) suggested that even though cells can be actively oxidizing ammonia at low $\mathrm{pH}$, the energy produced is enough to maintain cell but not for growth (Allison and Prosser, 1993). In this case, metatranscriptomics helps to better determine who is active in certain conditions (Prosser, 2015) regardless of the change in gene abundance (as increase in gene abundance is a presumptive measure of growth in incubation assays). However, RNA extraction from soil is not as simple as for DNA and in this work it was more successful after soil incubations, where we could successfully observe an AOA amoA transcripts in the Campo sujo-only slurry incubation after 21 days.

Some other process of $\mathrm{NO}_{3}^{-}$use by the microbiota should be considered in further studies, i.e. competition for $\mathrm{NH}_{4}{ }^{+}$by plants or heterotrophic microbes, as described in Californian grasslands (Jackson et al., 1989); dissimilatory reduction of $\mathrm{NO}_{3}{ }^{-}$to $\mathrm{NH}_{4}{ }^{+}$(DNRA) (Chen et al., 2015; Cole and Brown, 1980); abiotic $\mathrm{NO}_{3}^{-}$immobilization according to the ferrous wheel hypothesis (Jiang et al., 2015), or the clay fixation of $\mathrm{NH}_{4}^{+}$.

The competition for $\mathrm{NH}_{3}$ between plant roots, nitrifying and heterotrophic bacteria has been reviewed before (Verhagen et al., 1994). Verhagen et al. showed that heterotrophic and plant roots win the competition for ammonium, in this order, against nitrifiers, and they also could not find a nitrification inhibition by plants allelochemicals. However, the works considered by them have compared heterotrophic organisms with $\mathrm{N}$. europaea. New studies should consider the competition for $\mathrm{NH}_{3}$ between hetetrophic with $\mathrm{AOA}$ and $\mathrm{AOB}$.

This thesis focused on the understanding of autotrophic ammonia oxidation by Archaea and Bacteria in the Cerrado soil, but the results obtained, along with the literature suggest that future work should expand on the heterotrophic nitrification in these soils and specifically with regard to fungal community. The use of specific inhibitors for bacteria or fungi show the capacity of fungi to nitrify $\mathrm{NH}_{4}{ }^{+}$and organic $\mathrm{N}$ in grassland soils (Laughlin et al., 2008). Zhu et al. also suggest that the higher $\mathrm{NO}_{3}{ }^{-}$immobilization rate in the soils under the woodland than in the tea plantation was an efficient way of conservation of produced $\mathrm{NO}_{3}^{-}$by the heterotrophic nitrification (Zhu et al., 2014).

This work focused on the microbial perspective of the natural conservation of $\mathrm{N}$ in the Cerrado soils. Our look is misleading, more preoccupied with the systems that increase 
$\mathrm{N}$ loss than understanding how some systems, and their microbiota, maintain low $\mathrm{N}$ losses. The input of fertilizers in lower concentration, the maintenance of high C:N ratio with addition of organic matter rich in C or the non-continuous supply of nutrients (i.e. the use of biochar), which seems to keep a dynamic between plants and microorganisms are some solutions to be addressed to lower nutrient loss. But also, the change of land use leads to a decrease in soil microbial diversity; in turn, loss of functional diversity has been associated with the decrease in ecosystem multifunctionality (Bradford et al., 2014), potentially reflecting on the provision of ecological services. So greater aboveground diversity might allow similar increase in the belowground and consequently facilitate the sustainability of soil functions.

Paralleling what the philosopher Edgar Morin suggests for complex systems, the study of soil needs to distinguish the components that compose the soil and to consider that the all is formed by smaller parts, but these, in turn, interact with each other in a way that the sum of parts is smaller than the all. The tendency is to have more multidisciplinary studies linking soil physics, plant physiology and genetics, soil microbiology, biostatistics, network modelling to understand soil's behavior face to natural or anthropogenic disturbances. 


\section{Capítulo 6 - Conclusões e perspectivas}

$\checkmark \quad$ Baixas taxas de nitrificação líquida nos solos do Cerrado

$\checkmark \quad$ Alta abundância de genes relative à oxidação de amônia

$\checkmark \quad$ Presença de oxidantes de amônia em solos do Cerrado, dos Domínios Archaea e Bacteria, no entanto, em baixa abundância quando comparado a outros solos

$\checkmark \quad$ AOA são mais abundantes que AOB, tal como esperado devido ao baixo pH típico dos solos de Cerrado

$\checkmark \quad$ O cultivo da soja (manejo, fertilização, calagem e a monocultura) alteraram a abundância de AOA e AOB em um curto período de tempo (134 dias)

$\checkmark \quad$ AOA e AOB podem estar dormentes ou desenvolvendo outras funções nos solos do Cerrado

$\checkmark \quad$ A nitrificação não é limitada por pH, água ou inibidores biológicos

$\checkmark \quad$ O perfil de DGGE indica uma composição de baixo número de bandas de AOA, sugerindo uma baixa diversidade desse grupo nos solos de Cerrado

$\checkmark \quad$ Em termos de processos de baixo espectro, como aqueles relativos ao ciclo do nitrogênio, a diversidade e a estrutura da comunidade microbiana são importantes fatores para o funcionamento do ciclo

Considerando o que foi relatado nos trabalhos desta tese, algumas perspectivas para trabalhos futuros são enumeradas abaixo:

A comunidade fúngica deveria ser considerada em futuras análises da limitação do crescimento de oxidantes de amônia

> A modificação na dinâmica de $\mathrm{N}$ dirigida à conservação de $\mathrm{NH}_{4}{ }^{+}$pode ser avaliada considerando também a taxa bruta de nitrificação pelo método de diluição de ${ }^{15} \mathrm{NO}_{3}{ }^{-}$

$>$ Devido à maior razão entre $\mathrm{NH}_{4}{ }^{+}$e $\mathrm{NO}_{3}{ }^{-}$nos solos do Cerrado, um estudo futuro deve avaliar a comunidade de organismos que realizam redução dissimilatória de nitrato a amônia

O estudo do fluxo de $\mathrm{N}$ nos compartimentos do solo e a microbiota associada à assimilação de $\mathrm{N}$ pode ser acompanhada pelo isótopo $15 \mathrm{~N}$ 


\section{References}

ALLISON, S. M.; PROSSER, J. I. Ammonia oxidation at low $\mathrm{pH}$ by attached populations of nitrifying bacteria. Soil Biology and Biochemistry, v. 25, n. 7, 1993.

ANDREOTE, F. D.; JIMENEZ, D. J.; CHAVES, D.; DIAS, A. C.; LUVIZOTTO, D. M.; DINI-ANDREOTE, F.; FASANELLA, C. C.; LOPEZ, M. V.; BAENA, S.; TAKETANI, R. G.; DE MELO, I. S. The microbiome of Brazilian mangrove sediments as revealed by metagenomics. PLoS One, v. 7, n. 6, p. e38600, 2012.

ARAUJO, J. F.; DE CASTRO, A. P.; COSTA, M. M.; TOGAWA, R. C.; JUNIOR, G. J.; QUIRINO, B. F.; BUSTAMANTE, M. M.; WILLIAMSON, L.; HANDELSMAN, J.; KRUGER, R. H. Characterization of soil bacterial assemblies in Brazilian savanna-like vegetation reveals acidobacteria dominance. Microbial ecology, v. 64, n. 3, p. 760-70, Oct 2012.

ARMSTRONG, E. F.; PROSSER, J. I. Growth of Nitrosomonas europaea on ammonia-treated vermiculite. Soil Biology and Biochemistry, v. 20, n. 3, p. 409-411, 1988.

AVERILL, C.; TURNER, B. L.; FINZI, A. C. Mycorrhiza-mediated competition between plants and decomposers drives soil carbon storage. Nature, v. 505, n. 7484, p. 543-5, Jan 232014.

BÁRCENAS-MORENO, G.; BÅÅTH, E.; ROUSK, J. Functional implications of the pH-trait distribution of the microbial community in a re-inoculation experiment across a $\mathrm{pH}$ gradient. Soil Biology and Biochemistry, v. 93, p. 69-78, 2016.

BARTOSSEK, R.; SPANG, A.; WEIDLER, G.; LANZEN, A. Metagenomic analysis of ammoniaoxidizing archaea affiliated with the soil group. Frontiers in Microbiology, v. 3, n. 208, p. 1-14, 2012.

BEUCHLE, R.; GRECCHI, R. C.; SHIMABUKURO, Y. E.; SELIGER, R. Land cover changes in the Brazilian Cerrado and Caatinga biomes from 1990 to 2010 based on a systematic remote sensing sampling approach. Applied Geography, v. 58, p. 116-127, 2015.

$\mathrm{BIRCH}, \mathrm{A}$. F. Mineralisation of plant nitrogen following alternate wet and dry conditions. Plant and Soil, v. 24, p. 333-339, 1964.

BLAINEY, P. C.; MOSIER, A. C.; POTANINA, A.; FRANCIS, C. A.; QUAKE, S. R. Genome of a lowsalinity ammonia-oxidizing archaeon determined by single-cell and metagenomic analysis. PLoS One, v. 6, n. 2, p. e16626, 2011.

BOTHE, H.; JOST, G.; SCHLOTER, M.; WARD, B. B.; K., W. Molecular analysis of ammonia oxidation and denitrification in natural environments. FEMS Microbiol Rev, v. 24, p. 673-690, 2000.

BRADFORD, M. A.; WOOD, S. A.; BARDGETT, R. D.; BLACK, H. I.; BONKOWSKI, M.; EGGERS, T.; GRAYSTON, S. J.; KANDELER, E.; MANNING, P.; SETÄLÄ, H.; JONES, T. H. Discontinuity in the responses of ecosystem processes and multifunctionality to altered soil community composition. Proceedings of the National Academy of Sciences of the United States of America, v. 111, n. 40, p. 14478-14483, 2014. 
BRAKER, G.; MATTHIES, D.; HANNIG, M.; BRANDT, F. B.; BRENZINGER, K.; GRÖNGRÖFT, A. Impact of Land Use Management and Soil Properties on Denitrifier Communities of Namibian Savannas. Microbial ecology, v. 70, n. 4, p. 981-92, 2015.

BRESOLIN, J. D.; BUSTAMANTE, M. M.; KRUGER, R. H.; SILVA, M. R.; PEREZ, K. S. Structure and composition of bacterial and fungal community in soil under soybean monoculture in the Brazilian Cerrado. Brazilian Journal of Microbiology, v. 41, n. 2, p. 391-403, Apr 2010.

BRU, D.; RAMETTE, A.; SABY, N. P.; DEQUIEDT, S.; RANJARD, L.; JOLIVET, C.; ARROUAYS, D.; PHILIPPOT, L. Determinants of the distribution of nitrogen-cycling microbial communities at the landscape scale. The ISME journal, v. 5, n. 3, p. 532-42, 2011.

BURTON, S. A. Q.; PROSSER, J. I. Autotrophic Ammonia Oxidation at Low pH through Urea Hydrolysis. Applied and environmental microbiology, v. 67, n. 7, p. 29522957, 2001.

BUSTAMANTE, M.; VERDEJO, V.; ZÚÑIGA, C. Comparison of water availability effect on ammonia-oxidizing bacteria and archaea in microcosms of a Chilean semiarid soil. Frontiers in Microbiology, v. 3, n. 282, p. 1-10, 2012 a.

BUSTAMANTE, M. M. C.; DE BRITO, D. Q.; KOZOVITS, A. R.; LUEDEMANN, G.; DE MELLO, T. R. B.; PINTO, A. S.; MUNHOZ, C. B. R.; TAKAHASHI, F. S. C. Effects of nutrient additions on plant biomass and diversity of the herbaceous-subshrub layer of a Brazilian savanna (Cerrado). Plant Ecology, v. 213, n. 5, p. 795-808, 2012b.

BUSTAMANTE, M. M. C.; MEDINA, E.; ASNER, G. P.; NARDOTO, G. B.; GARCIA-MONTIEL, D. C. Nitrogen cycling in tropical and temperate savannas. Biogeochemistry, v. 79, p. 209-237, 2006.

BUSTAMANTE, M. M. C.; NARDOTO, G. B.; PINTO, A. S.; RESENDE, J. C. F.; TAKAHASHI, F. S. C.; VIEIRA, L. C. G. Potential impacts of climate change on biogeochemical functioning of Cerrado ecosystems. Brazilian Journal of Biology, v. 72, n. 3, p. 655-671, 2012c.

CARSON, J. K.; GONZALEZ-QUIÑONES, V.; MURPHY, D. V.; HINZ, C.; SHAW, J. A.; GLEESON, D. B. Low pore connectivity increases bacterial diversity in soil. Applied and environmental microbiology, v. 76, n. 12, p. 3936-3942, 2010.

CARVALHO, J. L. N.; CERRI, C. E. P.; FEIGL, B. J.; PICCOLO, M. C.; GODINHO, V. P.; CERRI, C. C. Carbon sequestration in agricultural soils in the Cerrado region of the Brazilian Amazon. Soil Tillage Research, v. 103, n. 2, p. 342-349, 2009.

CASTALDI, S.; ERMICE, A.; STRUMIA, S. Fluxes of $\mathrm{N} 2 \mathrm{O}$ and $\mathrm{CH} 4$ from soils of savannas and seasonally-dry ecosystems. Journal of Biogeography, v. 33, p. 401-415, 2006.

CATÃO, E.; CASTRO, A. P.; BARRETO, C. C.; KRUGER, R. H.; KYAW, C. M. Diversity of Archaea in Brazilian savanna soils. Arch Microbiol, v. 195, n. 7, p. 507-12, Jul 2013.

CATÃO, E. C. P.; LOPES, F. A. C.; DA SILVA, M. R. R. S.; SANTANA, R. H.; BUSTAMANTE, M. M. C.; KRÜGER, R. H. Diversity and Function of Bacterial Assemblages in Savanna Vegetation Soils. In: MAHESHWARI, D. K. (Ed.). Sustainable Development and Biodiversity: Springer International Publishing, v.1, 2014. p.147-165.

CATÃO, E. C. P.; LOPES, F. A. C.; RUBINI, M. R.; NARDOTO, G. B.; PROSSER, J. I.; KRÜGER, R. H. Short-term impact of soybean management on ammonia oxidizers in a Brazilian savanna under 
restoration as revealed by coupling different techniques. Biology and Fertility of Soils, v. 52, n. 3, p. 401-412, 2016.

CHEN, Z.; WANG, C.; GSCHWENDTNER, S.; WILLIBALD, G. Relationships between denitrification gene expression, dissimilatory nitrate reduction to ammonium and nitrous oxide and dinitrogen production in montane grassland soils. Soil Biology and Biochemistry, v. 87, p. 6777, 2015.

CHOI, P. S.; NAAL, Z.; MOORE, C.; CASADO-RIVERA, E.; ABRUNA, H. D.; HELMANN, J. D.; SHAPLEIGH, J. P. Assessing the impact of denitrifier-produced nitric oxide on other bacteria. Applied Environmental Microbiology, v. 72, n. 3, p. 2200-5, Mar 2006.

CLEVELAND, C. C.; LIPTZIN, D. C:N:P stoichiometry in soil: is there a "Redfield ratio" for the microbial biomass? Biogeochemistry, v. 85, p. 235-252, 2007.

CLEVELAND, C. C.; TOWNSEND, A. R.; SCHIMEL, D. S.; FISHER, H.; HOWARTH, R. W.; HEDIN, L. O.; PERAKIS, S. S.; LATTY, E. F.; VON FISCHER, J. C.; ELSEBOARD, A.; WASSON, M. F. Global patterns of terrestrial biological nitrogen (N2) fixation in natural ecosystems. Global Biogeochemical Cycles, v. 13, n. 2, p. 623-645, 1999.

COBO-DÍAZ, J. F.; FERNÁNDEZ-GONZÁLEZ, A. J.; VILLADAS, P. J.; ROBLES, A. B.; TORO, N.; FERNÁNDEZ-LÓPEZ, M. Metagenomic assessment of the potential microbial nitrogen pathways in the rhizosphere of a mediterranean forest after a wildfire. Microbial ecology, v. 69, n. 4, p. 895-904, 2015.

COLE, J. A.; BROWN, C. M. Nitrite reduction to ammonia by fermentative bacteria: a short circuit in the biological nitrogen cycle. FEMS Microbiology Letters, v. 7, n. 2, p. 65-72, 1980.

COLMAN, B. P.; FIERER, N.; SCHIMEL, J. P. Abiotic nitrate incorporation, anaerobic microsites, and the ferrous wheel. Biogeochemistry, 2008.

CONRAD, R. Soil microorganisms as controllers of atmospheric trace gases $(\mathrm{H} 2, \mathrm{CO}, \mathrm{CH} 4, \mathrm{OCS}$, N2O, and NO). Microbiol Rev, v. 60, n. 4, p. 609-40, Dec 1996.

CRUVINEL, Ê. B. F.; BUSTAMANTE, M. M. C.; KOZOVITS, A. R. K.; ZEPP, R. G. Soil emissions of $\mathrm{NO}, \mathrm{N} 2 \mathrm{O}$ and $\mathrm{CO} 2$ from croplands in the savanna region of central Brazil. Agriculture, Ecosystems \& Environment, v. 144, n. 1, p. 29-40, 2011.

DA SILVA, M. R. R. S. Produção de serrapilheira, biomassa e diversidade de comunidades bacterianas do solo em áreas de Cerrado sob diferentes usos e manejos. 2004. (Master). Departamento de Ecologia, Universidade de Brasília, Brasília.

DA SILVA, M. R. S. S. Diversidade de comunidades bacterianas de solo de Cerrado em resposta a diferentes alterações dos ecossistemas. 2012. 154 (PhD). Departamento de Ecologia, Universidade de Brasília, Brasília.

DAIL, B. D.; DAVIDSON, E. A.; CHOROVER, J. Rapid abiotic transformation of nitrate in an acid forest soil. Biogeochemistry, v. 54, p. 131-146, 2001.

DAIMS, H.; LEBEDEVA, E. V.; PJEVAC, P.; HAN, P.; HERBOLD, C.; ALBERTSEN, M.; JEHMLICH, N.; PALATINSZKY, M.; VIERHEILIG, J.; BULAEV, A.; KIRKEGAARD, R. H.; VON BERGEN, M.; RATTEI, T.; BENDINGER, B.; NIELSEN, P. H.; WAGNER, M. Complete nitrification by Nitrospira bacteria. Nature, v. 528, n. 7583, p. 504-509, 2015. 
DALTON, H. Ammonia oxidation by the methane oxidising bacterium Methylococcus capsulatus strain bath. Archives in Microbiology, v. 114, n. 3, p. 273-279, 1977.

DAVIDSON, E. A.; CHOROVER, J.; DAIL, B. D. A mechanism of abiotic immobilization of nitrate in forest ecosystems: the ferrous wheel hypothesis. Global Change Biology, v. 9, n. 2, p. 228-236, 2003.

DAVIDSON, E. A.; DAIL, D. B.; CHOROVER, J. Iron interference in the quantification of nitrate in soil extracts and its effect on hypothesized abiotic immobilization of nitrate. Biogeochemistry, v. 90, p. 65-73, 2008.

DAVIDSON, E. A.; HART, S. C.; SHANKS, C. A.; FIRESTONE, M. K. Measuring gross nitrogen mineralization, immobilization, and nitrification by $15 \mathrm{~N}$ isotopic pool dilution in intact soil cores. European Journal of Soil Science, v. 42, n. 3, p. 335-349, 1991.

DAVIDSON, E. A.; KELLER, M.; ERICKSON, H. E.; VERCHOT, L. V.; VELDKAMP, E. Testing a Conceptual Model of Soil Emissions of Nitrous and Nitric Oxides. BioScience, v. 50, n. 8, p. 667, 2000.

DAVIDSON, E. A.; STARK, J. M.; FIRESTONE, M. K. Microbial production and consumption of nitrate in an annual grassland. Ecology, v. 71, n. 5, p. 1968-1975, 1990.

DE BOER, W.; DUYTS, H.; LAANBROEK, H. J. Urea stimulated autotrophic nitrification in suspensions of fertilized, acid heath soil. Soil Biology and Biochemistry, v. 21, p. 349-354, 1989.

DE BOER, W.; KLEIN GUNNEWIEK, P. J. A.; VEENHUIS, M.; BOCK, E.; LAANBROEK, H. J. Nitrification at low pH by aggregated chemolithotrophic bacteria. Applied and environmental microbiology, v. 57, n. 12, p. 3600-3604, 1991.

DE BOER, W.; KOWALCHUK, G. A. Nitrification in acid soils: micro-organisms and mechanisms. Soil Biology and Biochemistry, v. 33, n. 7-8, p. 853866, 2001.

DE CASTRO, A. P.; QUIRINO, B. F.; PAPPAS, G., JR.; KUROKAWA, A. S.; NETO, E. L.; KRUGER, R. $\mathrm{H}$. Diversity of soil fungal communities of Cerrado and its closely surrounding agriculture fields. Archives in Microbiology, v. 190, n. 2, p. 129-39, Aug 2008.

DELMONT, T. O.; PRESTAT, E.; KEEgAN, K. P.; FAUBLADIER, M.; ROBE, P.; CLARK, I. M.; PELLETIER, E.; HIRSCH, P. R.; MEYER, F.; GILBERT, J. A.; LE PASLIER, D.; SIMONET, P.; VOGEL, T. $M$. Structure, fluctuation and magnitude of a natural grassland soil metagenome. The ISME journal, v. 6, n. 9, p. 1677-87, Sep 2012.

DING, G.-C.; PRONK, G.; BABIN, D.; HEUER, H.; HEISTER, K.; KÖGEL-KNABNER, I.; SMALLA, K. Mineral composition and charcoal determine the bacterial community structure in artificial soils. FEMS microbiology ecology, v. 86, n. 1, p. 15-25, 2013.

ELOE-FADROSH, E. A.; IVANOVA, N. N.; WOYKE, T.; KYRPIDES, N. C. Metagenomics uncovers gaps in amplicon-based detection of microbial diversity. Nature Microbiology, v. 15032, p. 1-4, 2016.

ENWALL, K.; THROBÄCK, I. N.; STENBERG, M. Soil resources influence spatial patterns of denitrifying communities at scales compatible with land management. Applied and environmental microbiology, v. 76, n. 7, p. 2243-2250, 2010. 
ERGUDER, T. H.; BOON, N.; WITTEBOLLE, L.; MARZORATI, M.; VERSTRAETE, W. Environmental factors shaping the ecological niches of ammonia-oxidizing archaea. FEMS Microbiology Reviews, v. 33, n. 5, p. 855-869, 2009.

FALKOWSKI, P. G.; FENCHEL, T.; DELONG, E. F. The microbial engines that drive Earth's biogeochemical cycles. Science, v. 320, n. 5879, p. 1034-9, May 232008.

FAUTH, J. E.; BERNARDO, J.; CAMARA, M.; RESETARITS, W. J.; VAN BUSKIRK, J.; MCCOLLUM, S. A. Simplifying the jargon of community ecology: a conceptual approach. American Naturalist, v. 147, n. 2, p. 282-286, 1996.

FENCHEL, T. K., G.M.; BLACKBURN, H. . Bacterial Biogeochemistry: The Ecophysiology of Mineral Cycling. Academic Press, Elsevier, 2012. 303

FERNANDES, A. M.; ANDRADE, G. J. M.; SOUZA, E. F. C.; ROSOLEM, C. A. Brachiaria species affecting soil nitrification. Revista Brasileira de Ciência do Solo, v. 35, p. 1699-1706, 2011.

FIERER, N.; LAUBER, C. L.; RAMIREZ, K. S.; ZANEVELD, J.; BRADFORD, M. A.; KNIGHT, R. Comparative metagenomic, phylogenetic and physiological analyses of soil microbial communities across nitrogen gradients. The ISME journal, v. 6, n. 5, p. 1007-17, May 2012a.

FIERER, N.; LEFF, J. W.; ADAMS, B. J.; NIELSEN, U. N.; BATES, S. T.; LAUBER, C. L.; OWENS, S.; GILBERT, J. A.; WALL, D. H.; CAPORASO, J. G. Cross-biome metagenomic analyses of soil microbial communities and their functional attributes. Proceedings of the National Academy of Sciences of the United States of America, v. 109, n. 52, p. 21390-5, Dec 262012 b.

FILGUEIRAS, T. Herbaceous plant Communities. In: OLIVEIRA, P. M., RJ (Ed.). The cerrados of Brazil: ecology and natural history of a Neotropical savanna. New York: Columbia University Press, 2002. cap. 7, p.121-139.

FRAPS, G. S.; STERGES, A. J. CAUSES OF LOW NITRIFICATION CAPACITY OF CERTAIN SOILS. Soil Science, v. 34, n. 5, p. 353-364, 1932.

GALLOWAY, J. N.; COWLING, E. B. Reactive nitrogen and the world: 200 years of change. Ambio, v. 31, n. 2, p. 64-71, Mar 2002.

GELFAND, I.; YAKIR, D. Influence of nitrite accumulation in association with seasonal patterns and mineralization of soil nitrogen in a semi-arid pine forest. Soil Biology and Biochemistry, $v$. 40, p. 415-424, 2008.

GOMES, R. C.; SEMEDO, L. T.; SOARES, R. M.; ALVIANO, C. S.; LINHARES, L. F.; COELHO, R. R. Chitinolytic activity of actinomycetes from a cerrado soil and their potential in biocontrol. Letters Applied Microbiology, v. 30, p. 146-150, 2000.

GRAF, D. R.; JONES, C. M.; HALLIN, S. Intergenomic comparisons highlight modularity of the denitrification pathway and underpin the importance of community structure for N2O emissions. PLoS One, v. 9, n. 12, p. e114118, 2014.

GRAHAM, E. B.; WIEDER, W. R.; LEFF, J. W.; WEINTRAUB, S. R.; TOWNSEND, A. R.; CLEVELAND, C. C.; PHILIPPOT, L.; NEMERGUT, D. R. Do we need to understand microbial communities to predict ecosystem function? A comparison of statistical models of nitrogen cycling processes. Soil Biology and Biochemistry, v. 68, p. 279-282, 2014. 
GREMION, F.; CHATZINOTAS, A.; HARMS, H. Comparative 16S rDNA and 16S rRNA sequence analysis indicates that Actinobacteria might be a dominant part of the metabolically active bacteria in heavy metal-contaminated bulk and rhizosphere soil. Environmental microbiology, v. 5, n. 10 , p. 896-907, Oct 2003.

GRIFFITHS, R. I.; THOMSON, B. C.; JAMES, P.; BELL, T.; BAILEY, M.; WHITELEY, A. S. The bacterial biogeography of British soils. Environmental microbiology, v. 13, n. 6, p. 1642-54, Jun 2011.

GUBRY-RANGIN, C., ; NICOL, G. W.; PROSSER, J. I. Archaea rather than bacteria control nitrification in two agricultural acidic soils. FEMS microbiology ecology, v. 74, n. 3, p. 566-574, 2010.

GUBRY-RANGIN, C.; HAI, B.; QUINCE, C.; ENGEL, M.; THOMSON, B. C.; JAMES, P.; SCHLOTER, M.; GRIFFITHS, R. I.; PROSSER, J. I.; NICOL, G. W. Niche specialization of terrestrial archaeal ammonia oxidizers. Proceedings of the National Academy of Sciences of the United States of America, v. 108, n. 52, p. 21206-21211, 2011.

HAMMER, O.; HARPER, D. A. T.; RYAN, P. D. PAST: Paleontological Statistics software package for education and data analysis. Palaeontologica Eletronica, v. 4, n. 1, p. 9, 2001.

HARIDASAN, M. Solos. In: FELFILI, J. M.;REZENDE, A. V. e SILVA-JÚNIOR, M. C. (Ed.). Bioma Cerrado: vegetação e solos da Chapada dos Veadeiros. Brasília: UnB/FINATEC, 2007. p.256.

HATZENPICHLER, R.; LEBEDEVA, E. V. A moderately thermophilic ammonia-oxidizing crenarchaeote from a hot spring. Proceedings of the National Academy of Sciences, v. 105, n. 6, p. 2134-2139, 2008.

HEIL, J.; VEREECKEN, H.; BRÜGGEMANN, N. A review of chemical reactions of nitrification intermediates and their role in nitrogen cycling and nitrogen trace gas formation in soil. European Journal of Soil Science, v. 67, n. 1, p. 23-39, 2015.

HERNÁNDEZ-HERNÁNDEZ, R. M.; LÓPEZ-HERNÁNDEZ, D. Microbial biomass, mineral nitrogen and carbon content in savanna soil aggregates under conventional and no-tillage. Soil Biology and Biochemistry, v. 34, p. 1563-1570, 2002.

JACKSON, L. E.; SCHIMEL, J. P.; FIRESTONE, M. K. Short-term partitioning of ammonium and nitrate between plants and microbes in an annual grassland. Soil Biology and Biochemistry, $v$. 21, n. 3, p. 409-415, 1989.

JACOBSON, T. K.; BUSTAMANTE, M. M.; KOZOVITS, A. R. Diversity of shrub tree layer, leaf litter decomposition and $\mathrm{N}$ release in a Brazilian Cerrado under $\mathrm{N}, \mathrm{P}$ and $\mathrm{N}$ plus $\mathrm{P}$ additions. Environmental Pollution, v. 159, n. 10, p. 2236-42, Oct 2011.

JANGID, K.; WILLIAMS, M. A.; FRANZLUEBBERS, A. J.; SCHMIDT, T. M.; COLEMAN, D. C.; WHITMAN, W. B. Land-use history has a stronger impact on soil microbial community composition than aboveground vegetation and soil properties. Soil Biology and Biochemistry, v. $43,2011$.

JIA, Z.; CONRAD, R. Bacteria rather than Archaea dominate microbial ammonia oxidation in an agricultural soil. Environmental microbiology, v. 11, n. 7, p. 1658-1671, 2009.

JIANG, X.; MA, Y.; YUAN, J.; WRIGHT, A. L.; LI, H. Soil particle surface electrochemical property effects on abundance of ammonia oxidizing bacteria and ammonia-oxidizing archaea, $\mathrm{NH} 4+$ 
activity and net nitrification in an acid soil. Soil Biology and Biochemistry, v. 43, p. 2215-2221, 2011.

JIANG, X.; XIN, X.; LI, S.; ZHOU, J.; ZHU, T.; MÜLLER, C.; CAI, Z.; WRIGHT, A. L. Effects of Fe oxide on $\mathrm{N}$ transformations in subtropical acid soils. Scientific reports, v. 5, n. 8615, p. 1-8, 2015.

JOHNSON, D. W.; CHENG, W.; BURKE, I. C. Biotic and abiotic nitrogen retention in a variety of forest soils. Soil Science society of America Journal, v. 64, p. 1503-1514, 2000.

JONES, C. M.; GRAF, D. R.; BRU, D.; PHILIPPOT, L.; HALLIN, S. The unaccounted yet abundant nitrous oxide-reducing microbial community: a potential nitrous oxide sink. The ISME journal, v. 7, n. 2, p. 417-26, Feb 2013.

JONES, C. M.; HALLIN, S. Ecological and evolutionary factors underlying global and local assembly of denitrifier communities. The ISME journal, v. 4, p. 633-641, 2010.

JONES, C. M.; SPOR, A.; BRENNAN, F. P.; BREUIL, M.-C.; BRU, D.; LEMANCEAU, P.; GRIFFITHS, B.; HALLIN, S.; PHILIPPOT, L. Recently identified microbial guild mediates soil N2O sink capacity. Nature Climate Change, v. 4, n. 9, p. 801-805, 2014.

KANTER, D.; MAUZERALL, D. L.; RAVISHANKARA, A. R.; DANIEL, J. S.; PORTMANN, R. W.; GRABIEL, P. M.; MOOMAW, W. R.; GALLOWAY, J. N. A post-Kyoto partner: considering the stratospheric ozone regime as a tool to manage nitrous oxide. Proceedings of the National Academy of Sciences of the United States of America, v. 110, n. 12, p. 4451-4457, 2013.

KLINK, C. A.; MACHADO, R. B. A conservação do Cerrado brasileiro. Megadiversidade, v. 1, p. 147-153, 2005.

KÖLLN, O. T.; FRANCO, H. C. J.; FERREIRA, D. A.; VARGAS, V. P.; CASTRO, S. A. Q.; CANTARELLA, H.; CALDANA, C.; TRIVELIN, P. C. O. Root extracts of Bracchiaria humidicola and Saccharum spontaneum to increase N use by sugarcane. Scientia Agricola, v. 73, n. 1, p. 34-42, 2016.

KOWALCHUK, G. A.; STEPHEN, J. R. Ammonia-oxidizing bacteria: a model for molecular microbial ecology. Annual review of microbiology, v. 55, p. 485-529, 2001.

KOZOVITS, A. R.; BUSTAMANTE, M. M. C.; GAROFALO, C. R. Nutrient resorption and patterns of litter production and decomposition in a Neotropical Savanna. Functional Ecology, v. 21, n. 6, p. 1034-1043, 2007.

KUENEN, J. G.; ROBERTSON, L. A. Combined nitrification-denitrication processes. FEMS Microbiology Reviews, v. 15, p. 109-117, 1994.

KURAMAE, E. E.; YERGEAU, E.; WONG, L. C.; PIJL, A. S.; VAN VEEN, J. A.; KOWALCHUK, G. A. Soil characteristics more strongly influence soil bacterial communities than land-use type. FEMS microbiology ecology, v. 79, n. 1, p. 12-24, Jan 2012.

LANNES, L. S.; BUSTAMANTE, M. M.; EDWARDS, P. J.; VENTERINK, H. O. Alien and endangered plants in the Brazilian Cerrado exhibit contrasting relationships with vegetation biomass and $\mathrm{N}$ : P stoichiometry. New Phytologist, v. 196, n. 3, p. 816-23, Nov 2012.

LAROSE, C.; DOMMERGUE, A.; VOGEL, T. Microbial nitrogen cycling in Arctic snowpacks. Environmental Research Letters, v. 8, p. 1-9, 2013. 
LASSALETTA, L.; BILLEN, G.; GRIZZETTI, B.; GARNIER, J.; LEACH, A. M.; GALLOWAY, J. N. Food and feed trade as a driver in the global nitrogen cycle: 50-year trends. Biogeochemistry, $\mathrm{v}$. 118, p. 225-241, 2014.

LAUBER, C. L.; HAMADY, M.; KNIGHT, R.; FIERER, N. Pyrosequencing-based assessment of soil $\mathrm{pH}$ as a predictor of soil bacterial community structure at the continental scale. Applied and environmental microbiology, v. 75, n. 15, p. 5111-20, Aug 2009.

LAUGHLIN, R. J.; STEVENS, R. J.; MÜLLER, C.; WATSON, C. J. Evidence that fungi can oxidize $\mathrm{NH} 4+$ to NO3- in a grassland soil. European Journal of Soil Science, v. 59, p. 285-291, 2008.

LAZCANO, C.; GÓMEZ-BRANDÓN, M.; REVILLA, P.; DOMÍNGUEZ, J. Short-term effects of organic and inorganic fertilizers on soil microbial community structure and function. Biology and Fertility of Soils, v. 49, p. 723-733, 2013.

LEBLANC, J. C.; GONCALVES, E. R.; MOHN, W. W. Global response to desiccation stress in the soil actinomycete Rhodococcus jostii RHA1. Applied Environmental Microbiology, v. 74, n. 9, p. 2627-36, 2008.

LEHTOVIRTA-MORLEY, L. E.; STOECKER, K.; VILCINSKAS, A.; PROSSER, J. I.; NICOL, G. W. Cultivation of an obligate acidophilic ammonia oxidizer from a nitrifying acid soil. Proceedings of the National Academy of Sciences, v. 108, n. 38, p. 15892-7, Sep 202011.

LEININGER, S.; URICH, T.; SCHLOTER, M.; SCHWARK, L.; QI, J.; NICOL, G.; PROSSER, J.; SCHUSTER, S.; SCHLEPER, C. Archaea predominate among ammonia-oxidizing prokaryotes in soils. Nature, v. 442, n. 7104, p. 806-809, 2006.

LEVIČNIK-HÖFFERLE, S.; NICOL, G. W.; AUSEC, L.; MANDIĆ-MULEC, I.; PROSSER, J. I. Stimulation of thaumarchaeal ammonia oxidation by ammonia derived from organic nitrogen but not added inorganic nitrogen. FEMS microbiology ecology, v. 80, n. 1, p. 114-123, 2012.

LEVINE, U. Y.; TEAL, T. K.; ROBERTSON, P. G.; SCHMIDT, T. M. Agriculture's impact on microbial diversity and associated fluxes of carbon dioxide and methane. The ISME journal, v. 5, n. 10, p. 1683-1691, 2011.

LOPES, F. A.; CATAO, E. C.; SANTANA, R. H.; CABRAL ADE, S.; PARANHOS, R.; RANGEL, T. P.; REZENDE, C. E.; EDWARDS, R. A.; THOMPSON, C. C.; THOMPSON, F. L.; KRUGER, R. H. Microbial Community Profile and Water Quality in a Protected Area of the Caatinga Biome. PLoS One, v. 11, n. 2, p. e0148296, 2016.

LU, L.; HAN, W.; ZHANG, J.; WU, Y.; WANG, B.; LIN, X.; ZHU, J.; CAI, Z.; JIA, Z. Nitrification of archaeal ammonia oxidizers in acid soils is supported by hydrolysis of urea. The ISME journal, v. 6, n. 10, p. 1978-1984, 2012.

MAGNUSSON, W. E.; LIMA, A. P.; LUIZÃO, R.; LUIZÃO, F.; COSTA, F. F. C.; DE CASTILHO, C. V.; KINUPP, V. F. Rapeld: a modification of the gentry method for biodiversity surveys in long-term ecological research sites. Biota Neotropica, v. 5, n. 2, p. 1-6, 2005.

MAO, Y.; YANNARELL, A. C.; MACKIE, R. I. Changes in N-transforming archaea and bacteria in soil during the establishment of bioenergy crops. PLoS One, v. 6, n. 9, p. e24750, 2011.

MARRIS, E. The forgotten ecosystem. Nature, v. 437, n. 7061, p. 944-945, Oct 132005. 
MARTINY, J. B.; BOHANNAN, B. J.; BROWN, J. H.; COLWELL, R. K.; FUHRMAN, J. A.; GREEN, J. L.; HORNER-DEVINE, M. C.; KANE, M.; KRUMINS, J. A.; KUSKE, C. R.; MORIN, P. J.; NAEEM, S.; OVREAS, L.; REYSENBACH, A. L.; SMITH, V. H.; STALEY, J. T. Microbial biogeography: putting microorganisms on the map. Nature Reviews Microbiology, v. 4, n. 2, p. 102-12, 2006.

MCLAIN, J.; MARTENS, D. A. N2O production by heterotrophic $\mathrm{N}$ transformations in a semiarid soil. Applied Soil Ecology, v. 32, n. 2, p. 253-263, 2006.

MEDINA, E. Nutrients; requirements, conservation and cycles of nutrients in the herbaceous layer. In: WALKER, B. H. (Ed.). Determinants of Tropical Savannas. Oxford, UK: IR Press, 1987. p.39-65.

MENDES, I. C.; DE SOUSA, D. M. G.; REIS JUNIOR, F. B. Bioindicadores de qualidade de solo: dos laboratórios de pesquisa para o campo. Cadernos de Ciência \& Tecnologia, v. 32, n. 1/2, p. 191-209, 2016.

MENDES, I. C.; FERNANDES, M. F.; CHAER, G. M.; JUNIOR, F. B. R. Biological functioning of Brazilian Cerrado soils under different vegetation types. Plant Soil, v. 359, p. 183-195, 2012.

MENDES, I. C.; HUNGRIA, M.; VARGAS, M. A. T. Soybean response to starter nitrogen and Bradyrhizobium inoculation on a Cerrado Oxisol under no-tillage and conventional tillage systems. Revista Brasileira de Ciência do Solo, v. 27, p. 81-87, 2003.

MENDES, L. W.; KURAMAE, E. E.; NAVARRETE, A. A.; VAN VEEN, J. A.; TSAI, S. M. Taxonomical and functional microbial community selection in soybean rhizosphere. The ISME journal, v. 8, p. 1577-1587, 2014.

MMA, M. D. M. A. Cadastro Nacional de Unidades de Conservação. 2011. Disponível em: < http://www.mma.gov.br/sitio/index.php?ido=conteudo.monta\&idEstrutura=119 $>$. Acesso em: 18 of April.

MOHAN, S. B.; SCHMID, M.; JETTEN, M.; COLE, J. Detection and widespread distribution of the nrfA gene encoding nitrite reduction to ammonia, a short circuit in the biological nitrogen cycle that competes with denitrification. FEMS microbiology ecology, v. 49, n. 3, 2004.

MYeRS, N.; MITTERMEIER, R. A.; MITTERMEIER, C. G.; DA FONSECA, G. A. B.; KENT, J. Biodiversity hotspots for conservation priorities. Nature, v. 403, n. 6772, p. 853-858, Feb 24 2000.

NARDOTO, G. B.; BUSTAMANTE, M. M. C. Effects of fire on soil nitrogen dynamics and microbial biomass in savannas of Central Brazil. Pesquisa agropecuária brasileira, v. 38, n. 8, p. 955-962, 2003.

NAVARRETE, A. A.; TSAI, S. M.; MENDES, L. W.; FAUST, K.; DE HOLLANDER, M.; CASSMAN, N. A.; RAES, J.; VAN VEEN, J. A.; KURAMAE, E. E. Soil microbiome responses to the short-term effects of Amazonian deforestation. Molecular Ecology, v. 24, n. 10, p. 2433-48, May 2015.

NICOL G.W., S. C. Ammonia-oxidising Crenarchaeota: important players in the nitrogen cycle? Trends in microbiology, v. 14, n. 5, p. 207-212, 2006.

NICOL, G. W.; LEININGER, S.; SCHLEPER, C.; PROSSER, J. I. The influence of soil pH on the diversity, abundance and transcriptional activity of ammonia oxidizing archaea and bacteria. Environmental microbiology, v. 10, n. 11, p. 2966-78, Nov 2008. 
NICOL, G. W.; TSCHERKO, D.; EMBLEY, M. T.; PROSSER, J. I. Primary succession of soil Crenarchaeota across a receding glacier foreland. Environmental microbiology, v. 7, n. 3, p. 337-47, 2005.

NORTON, J. M.; ALZERRECA, J. J.; SUWA, Y.; KLOTZ, M. G. Diversity of ammonia monooxygenase operon in autotrophic ammonia-oxidizing bacteria. Archives in Microbiology, v. 177, p. 139-149, 2002.

NUGROHO, R. A.; RÖLING, W. F. M.; LAVERMAN, A. M.; VERHOEF, H. A. Low Nitrification Rates in Acid Scots Pine Forest Soils Are Due to pH-Related Factors. Microbial ecology, v. 53, n. 1, p. 89-97, 2007.

OSWALD, R.; BEHRENDT, T.; ERMEL, M.; WU, D.; SU, H.; CHENG, Y.; BREUNINGER, C.; MORAVEK, A.; MOUGIN, E.; DELON, C.; LOUBET, B.; POMMERENING-ROSER, A.; SORGEL, M.; POSCHL, U.; HOFFMANN, T.; ANDREAE, M. O.; MEIXNER, F. X.; TREBS, I. HONO emissions from soil bacteria as a major source of atmospheric reactive nitrogen. Science, v. 341, n. 6151, p. 1233-5, Sep 132013.

PAULA, F.; RODRIGUES, J.; ZHOU, J.; WU, L.; MUELLER, R.; MIRZA, B.; BOHANNAN, B.; NUSSLEIN, K.; DENG, Y.; TIEDJE, J.; PELLIZARI, V. Land use change alters functional gene diversity, composition and abundance in Amazon forest soil microbial communities. Molecular Ecology, v. 23, n. 12, p. 2988-99, Jun 2014.

PEIXOTO, R. S.; CHAER, G. M.; FRANCO, N.; REIS JUNIOR, F. B.; MENDES, I. C.; ROSADO, A. S. A decade of land use contributes to changes in the chemistry, biochemistry and bacterial community structures of soils in the Cerrado. Antonie Van Leeuwenhoek, v. 98, n. 3, p. 40313, Oct 2010.

PEREIRA DE CASTRO, A.; SARTORI DA SILVA, M. R.; QUIRINO, B. F.; DA CUNHA BUSTAMANTE, M. M.; KRUGER, R. H. Microbial Diversity in Cerrado Biome (Neotropical Savanna) Soils. PLoS One, v. 11, n. 2, p. e0148785, 2016.

PEREZ, K. S. S.; RAMOS, M. L. G.; MCMANUS, C. Nitrogênio da biomassa microbiana em solo cultivado com soja, sob diferentes sistemas de manejo, nos Cerrados. Pesquisa agropecuária brasileira, v. 40, n. 2, p. 137-144, 2005.

PESTER, M.; RATTEI, T.; FLECHL, S.; GRÖNGRÖFT, A.; RICHTER, A.; OVERMANN, J.; REINHOLD-HUREK, B.; LOY, A.; WAGNER, M. amoA-based consensus phylogeny of ammonia-oxidizing archaea and deep sequencing of amoA genes from soils of four different geographic regions. Environmental microbiology, v. 14, n. 2, 2012.

PETINATE, S. D.; BRANQUINHA, M. H.; COELHO, R. R.; VERMELHO, A. B.; GIOVANNI-DESIMONE, S. Purification and partial characterization of an extracellular serine-proteinase of Streptomyces cyaneus isolated from Brazilian cerrado soil. Journal of Applied Microbiology, v. 87, p. 557-563, 1997.

PFISTER, C. A.; MEYER, F.; ANTONOPOULOS, D. A. Metagenomic Profiling of a Microbial Assemblage Associated with the California Mussel: A Node in Networks of Carbon and Nitrogen Cycling. PLoS One, v. 5, n. 5, p. e10518, 2010.

PINHEIRO, J.; BATES, D.; DEBROY, S.; SARKAR, D.; TEAM, R. C. nlme: Linear and Nonlinear Mixed Effects Models 2015. 
PINTO, A. S.; BUSTAMANTE, M. M. C.; DA SILVA, M. R. S. S.; KISSELLE, K. W.; BROSSARD, M.; KRUGER, R.; ZEPP, R. G.; BURKE, R. A. Effects of Different Treatments of Pasture Restoration on Soil Trace Gas Emissions in the Cerrados of Central Brazil. Earth interactions, v. 10, p. 1-26, 2006.

PINTO, A. S.; BUSTAMANTE, M. M. C.; KISSELLE, K.; BURKE, R.; ZEPP, R.; VIANA, L. T.; VARELLA, R. F. M., M. Soil emissions of N 2 O, NO, and CO 2 in Brazilian Savannas: Effects of vegetation type, seasonality, and prescribed fires. Journal of Geophysical Research, v. 107, p. 1-9, 2002.

PLACELLA, S. A.; FIRESTONE, M. K. Transcriptional response of nitrifying communities to wetting of dry soil. Applied Environmental Microbiology, v. 79, n. 10, p. 3294-302, May 2013.

POOLE, R. K. Nitric oxide and nitrosative stress tolerance in bacteria. Biochem Soc Trans, v. 33, n. 1, p. 176-80, Feb 2005.

POTH, M.; ANDERSON, I. C.; MIRANDA, H. S.; MIRANDA, A. C.; RIGGAN, P. J. The magnitude and persistence of soil NO, N2O, $\mathrm{CH} 4$, and $\mathrm{CO2}$ fluxes from burned tropical savanna in Brazil. Global Biogeochemical Cycles, v. 9, n. 4, p. 503-513, 1995.

POWELL, S. J.; PROSSER, J. I. Inhibition of Biofilm Populations of Nitrosomonas europaea Microbial ecology, v. 24, p. 43-50, 1992.

PROSSER, J.; NICOL, G. Archaeal and bacterial ammonia-oxidisers in soil: the quest for niche specialisation and differentiation. Trends in microbiology, v. 20, n. 11, p. 523-531, 2012.

PROSSER, J. I. Dispersing misconceptions and identifying opportunities for the use of 'omics' in soil microbial ecology. Nature Reviews Microbiology, v. 13, n. 7, p. 439-446, 2015.

QUIRINO, B. F.; PAPPAS, G. J.; TAGLIAFERRO, A. C.; COLLEVATTI, R. G.; NETO, E. L.; DA SILVA, M. R.; BUSTAMANTE, M. M.; KRUGER, R. H. Molecular phylogenetic diversity of bacteria associated with soil of the savanna-like Cerrado vegetation. Microbiological Research, v. 164, n. 1, p. 59-70, 2009.

RACHID, C. T.; SANTOS, A. L.; PICCOLO, M. C.; BALIEIRO, F. C.; COUTINHO, H. L.; PEIXOTO, R. S.; TIEDJE, J. M.; ROSADO, A. S. Effect of sugarcane burning or green harvest methods on the Brazilian Cerrado soil bacterial community structure. PLoS One, v. 8, n. 3, p. e59342, 2013.

RAVISHANKARA, A. R.; DANIEL, J. S.; PORTMANN, R. W. Nitrous oxide (N2O): the dominant ozone-depleting substance emitted in the 21st century. Science, v. 326, n. 5949, p. 123-5, Oct 22009.

REATTO, A.; CORREIA, J. R.; SPERA, S. T. Solos do bioma Cerrado: aspectos pedológicos. In: SANO, S. M. e ALMEIDA, S. P. (Ed.). Cerrado: ambiente e flora. Planaltina: Embrapa-CPAC, 1998. cap. 2, p.47-86.

RIBEIRO, J. F.; WALTER, B. M. T. As principais fitofisionomias do Bioma Cerrado. In: SANO, S. M.;ALMEIDA, S. P. e RIBEIRO, J. F. (Ed.). Cerrado: ecologia e flora. Planaltina: Embrapa Cerrados 2008. p.151-212.

ROCKSTRÖM, J.; STEFFEN, W. L.; NOONE, K.; PERSSON, A.; III, S. F.; LAMBIN, E.; LENTON, T. M.; SCHEFFER, M.; FOLKE, C.; SCHELLNHUBER, H. Planetary boundaries: exploring the safe operating space for humanity. Ecology and Society, v. 14, n. 2, p. 32, 2009. 
ROESCH, L. F.; FULTHORPE, R. R.; RIVA, A.; CASELLA, G.; HADWIN, A. K.; KENT, A. D.; DAROUB, S. H.; CAMARGO, F. A.; FARMERIE, W. G.; TRIPLETT, E. W. Pyrosequencing enumerates and contrasts soil microbial diversity. The ISME journal, v. 1, n. 4, p. 283-90, Aug 2007.

ROSOLEM, C.; FOLONI, J.; OLIVEIRA, R. Nitrogen dynamics in soil as affected by liming and nitrogen fertilization, with straw on the soil surface. Pesquisa agropecuária brasileira, v. $38, \mathrm{n}$. 2, p. 301-309, 2003.

ROTTHAUWE, J. H.; WITZEL, K. P.; LIESACK, W. The ammonia monooxygenase structural gene amoA as a functional marker: molecular fine-scale analysis of natural ammonia-oxidizing populations. Applied Environmental Microbiology, v. 63, n. 12, p. 4704-12, Dec 1997.

ROUSK, J.; BAATH, E.; BROOKES, P. C.; LAUBER, C. L.; LOZUPONE, C.; CAPORASO, J. G.; KNIGHT, R.; FIERER, N. Soil bacterial and fungal communities across a $\mathrm{pH}$ gradient in an arable soil. The ISME journal, v. 4, n. 10, p. 1340-51, Oct 2010.

RÜTTING, T.; BOECKX, P.; MÜLLER, C.; KLEMEDTSSON, L. Assessment of the importance of dissimilatory nitrate reduction to ammonium for the terrestrial nitrogen cycle. Biogeosciences, v. 8, n. 7, p. 1779-1791, 2011.

SANCHEZ, M. P., F. . Fitofisionomias do Parque Estadual da Serra Azul. In: VENERE, P. C. e GARUTTI, V. (Ed.). Peixes do Cerrado:Parque Estadual da Serra Azul, Rio Araguaia, MT. . São Carlos: RIMA, 2011.

SHINN, M. B. Colorimetric Method for Determination of Nitrate. Industrial and Engineering Chemistry Analytical Edition, v. 13, n. 1, p. 33-35, 1941.

SKINNER, F. A.; WALKER, N. Growth of Nitrosomonas europaea in batch and continuous culture. Archives in Microbiology, v. 38, n. 4, p. 339-349, 1961.

SOUZA, R.; HUNGRIA, M.; CANTÃO, M.; VASCONCELOS, A.; NOGUEIRA, M.; VICENTE, V. Metagenomic analysis reveals microbial functional redundancies and specificities in a soil under different tillage and crop-management regimes. Applied Soil Ecology, v. 86, p. 106-112, 2015.

SOUZA, R. C.; CANTÃO, M. E.; VASCONCELOS, A. T. R.; NOGUEIRA, M. A.; HUNGRIA, M. Soil metagenomics reveals differences under conventional and no-tillage with crop rotation or succession. Applied Soil Ecology, v. 72, 2013.

SOUZA, R. C.; MENDES, I. C.; REIS-JUNIOR, F. B.; CARVALHO, F. M.; VASCONCELOS, A. T. R.; VICENTE, V. A.; HUNGRIA, M. Shifts in taxonomic and functional microbial diversity with agriculture: how fragile is the Brazilian Cerrado? . BioMed Central Microbiology, v. 16, n. 42, p. 1-15, 2016.

STAHL, D. A.; DE LA TORRE, J. R. Physiology and diversity of ammonia-oxidizing archaea. Annual Reviews in Microbiology, v. 66, p. 83-101, 2012.

STE-MARIE, C.; PARÉ, D. Soil, $\mathrm{pH}$ and $\mathrm{N}$ availability effects on net nitrification in the forest floors of a range of boreal forest stands. Soil Biology and Biochemistry, v. 31, p. 1579-1589, 1999.

STEMPFHUBER, B.; ENGEL, M.; FISCHER, D.; NESKOVIC-PRIT, G.; WUBET, T.; SCHÖNING, I.; GUBRY-RANGIN, C.; KUBLIK, S.; SCHLOTER-HAI, B.; RATTEI, T. pH as a Driver for AmmoniaOxidizing Archaea in Forest Soils. Microbial ecology, v. 69, n. 4, p. 879-883, 2015. 
STEPHEN, J. R.; KOWALCHUK, G. A.; BRUNS, M. A. V.; MCCAIG, A. E.; PHILLIPS, C. J.; EMBLEY, T. M.; PROSSER, J. I. Analysis of beta-subgroup proteobacterial ammonia oxidizer populations in soil by denaturing gradient gel electrophoresis analysis and hierarchical phylogenetic probing. Applied Environmental Microbiology, v. 64, n. 8, p. 2958-65, Aug 1998.

SU, H.; CHENG, Y.; OSWALD, R.; BEHRENDT, T.; TREBS, I.; MEIXNER, F. X.; ANDREAE, M. O.; CHENG, P.; ZHANG, Y.; POSCHL, U. Soil nitrite as a source of atmospheric $\mathrm{HONO}$ and $\mathrm{OH}$ radicals. Science, v. 333, n. 6049, p. 1616-8, Sep 162011.

SUBBARAO, G. V.; ITO, O.; SAHRAWAT, K. L. Scope and strategies for regulation of nitrification in agricultural systems-challenges and opportunities. Critical Reviews in Plant Sciences, v. 25, p. 303-335, 2006.

SUBBARAO, G. V.; NAKAHARA, K.; HURTADO, M. P.; ONO, H.; MORETA, D. E.; SALCEDO, A. F.; YOSHIHASHI, A. T.; ISHIKAWA, T.; ISHITANI, M.; OHNISHI-KAMEYAMA, M.; YOSHIDA, M.; RONDON, M.; RAO, I. M.; LASCANO, C. E.; BERRY, W. L.; ITO, O. Evidence for biological nitrification inhibition in Brachiaria pastures. Proceedings of the National Academy of Sciences of the United States of America, v. 106, n. 41, p. 17302-17307, 2009.

SUBBARAO, G. V.; NAKAHARA, K.; ISHIKAWA, T.; YOSHIHASHI, T.; ITO, O.; ONO, H.; OHNISHIKAMEYAMA, M.; YOSHIDA, M.; KAWANO, N.; BERRY, W. L. Free fatty acids from the pasture grass Brachiaria humidicola and one of their methyl esters as inhibitors of nitrification. Plant and Soil, v. 313, n. 1 p. 89-99, 2008.

SUBBARAO, G. V.; YOSHIHASHI, T.; WORTHINGTON, M.; NAKAHARA, K.; ANDO, Y.; SAHRAWAT, K. L.; RAO, I. M.; LATA, J.-C. C.; KISHII, M.; BRAUN, H.-J., J. Suppression of soil nitrification by plants. Plant science, v. 233, p. 155-164, 2015.

SUZUKI, I.; DULAR, U.; KWOK, S. C. Ammonia or ammonium ion as substrate for oxidation by Nitrosomonas europaea cells and extracts. Journal of Bacteriology, v. 120, n. 1, p. 556-558, 1974.

THION, C.; PROSSER, J. I. Differential response of nonadapted ammonia-oxidising archaea and bacteria to drying-rewetting stress. FEMS microbiology ecology, v. 90, n. 2, p. 380-9, Nov 2014.

TKACZ, A.; CHEEMA, J.; CHANDRA, G.; GRANT, A.; POOLE, P. S. Stability and succession of the rhizosphere microbiota depends upon plant type and soil composition. The ISME journal, v. 9, n. 11, p. 2349-59, Nov 2015.

TOURNA, M. F., T. E.; NICOL, G. W.; PROSSER, J. I. Growth, activity and temperature responses of ammonia-oxidizing archaea and bacteria in soil microcosms. Environmental microbiology, $\mathrm{v}$. 10, n. 5, p. 1357-64, May 2008.

VAJRALA, N., ;; MARTENS-HABBENA, W.; SAYAVEDRA-SOTO, L. A.; SCHAUER, A.; BOTTOMLEY, P. J.; STAHL, D. A.; ARP, D. J. Hydroxylamine as an intermediate in ammonia oxidation by globally abundant marine archaea. Proceedings of the National Academy of Sciences of the United States of America, v. 110, n. 3, p. 1006-1011, 2013.

VAN KESSEL, M. A. H. J.; SPETH, D. R.; ALBERTSEN, M.; NIELSEN, P. H.; DEN CAMP, H. J. M.; KARTAL, B.; JETTEN, M. S. M.; LÜCKER, S. Complete nitrification by a single microorganism. Nature, v. 528, n. 7583, p. 555-559, 2015. 
VANINSBERGHE, D.; MAAS, K. R.; CARDENAS, E.; STRACHAN, C. R.; HALLAM, S. J.; MOHN, W. W. Non-symbiotic Bradyrhizobium ecotypes dominate North American forest soils. The ISME journal, v. 9, n. 11, p. 2435-2441, 2015.

VERCHOT, L. V.; DAVIDSON, E. A.; CATTFINIO, J. H.; ACKERMAN, I. L.; ERICKSON, H. E.; KELLER, $M$. Land use change and biogeochemical controls of nitrogen oxide emissions from soils in eastern Amazonia Global Biogeochemical Cycles, v. 13, n. 1, p. 31-46, 1999.

VERHAGEN, F. J. M.; LAANBROEK, H. J.; WOLDENDROP, J. W. Competition for ammonium between plant roots and nitrifying and heterotrophic bacteria and the effects of protozoan grazing. Plant and Soil, v. 170, n. 2, p. 241-250, 1994.

VERHAMME, D. T.; PROSSER, J. I.; NICOL, G. W. Ammonia concentration determines differential growth of ammonia-oxidising archaea and bacteria in soil microcosms. The ISME journal, v. 5, n. 6, p. 1067-71, Jun 2011.

VIANA, L. T.; BUSTAMANTE, M. M. C.; MOLINA, M.; PINTO, A. D. S.; KISSELLE, K.; ZEPP, R.; BURKE, R. A. Microbial communities in Cerrado soils under native vegetation subjected to prescribed fire and under pasture. Pesquisa agropecuária brasileira, v. 46, p. 1665-1672, 2011.

VINHAL-FREITAS, I. C.; FERREIRA, A. S.; CORRÊA, G. F.; WENDLING, B. Land Use Impact on Microbial and Biochemical Indicators in Agroecosystems of the Brazilian Cerrado. Vadose Zone Journal, v. 12, p. 1-8, 2012.

VOS, M.; WOLF, A. B.; JENNINGS, S. J.; KOWALCHUK, G. A. Micro-scale determinants of bacterial diversity in soil. FEMS Microbiology Reviews, v. 37, n. 6, p. 936-954, 2013.

WEBER, E. B.; LEHTOVIRTA-MORLEY, L. E.; PROSSER, J. I.; GUBRY-RANGIN, C. Ammonia oxidation is not required for growth of Group 1.1c soil Thaumarchaeota. FEMS microbiology ecology, v. 91, n. 3, p. 1-7, 2015.

WEITZ, A. M.; VELDKAMP, E.; KELLER, M.; NEFF, J.; CRILL, P. M. Nitrous oxide, nitric oxide, and methane fluxes from soils following clearing and burning of tropical secondary forest. Journal of Geophysical Research, v. 103, n. D21, p. 28047, 1998.

WIDDEL, F.; BAK, F. Gram-Negative Mesophilic Sulfate-Reducing Bacteria. In: BALLOWS, A.;TRÜPER, H. G.;DWORKIN, M.;HARDER, W. e SCHLEIFER, K.-H. (Ed.). The Prokaryotes. A Handbook on the Biology of Bacteria: Ecophysiology, Isolation, Identification, Application 2nd: Springer, 1992. p.3352--3378

YACHI, S.; LOREAU, M. Biodiversity and ecosystem productivity in a fluctuating environment: the insurance hypothesis. Proceedings of the National Academy of Sciences of the United States of America, v. 96, n. 4, p. 1463-8, Feb 161999.

YANG, W. H.; HERMAN, D.; LIPTZIN, D.; SILVER, W. L. A new approach for removing iron interference from soil nitrate analysis. Soil Biology and Biochemistry, v. 46, p. 123-128, 2012.

ZAKIR, H. A.; SUBBARAO, G. V.; PEARSE, S. J.; GOPALAKRISHNAN, S.; ITO, O.; ISHIKAWA, T.; KAWANO, N.; NAKAHARA, K.; YOSHIHASHI, T.; ONO, H.; YOSHIDA, M. Detection, isolation and characterization of a root-exuded compound, methyl 3-(4-hydroxyphenyl) propionate, responsible for biological nitrification inhibition by sorghum (Sorghum bicolor). New Phytologist, v. 180, n. 2, p. 442-51, 2008. 
ZHANG, J.; SUN, W.; ZHONG, W.; CAl, Z. The substrate is an important factor in controlling the significance of heterotrophic nitrification in acidic forest soils. Soil Biology and Biochemistry, v. 76, p. 143-148, 2014.

ZHANG, L.-M. M.; OFFRE, P. R.; HE, J.-Z. Z.; VERHAMME, D. T.; NICOL, G. W.; PROSSER, J. I. Autotrophic ammonia oxidation by soil thaumarchaea. Proceedings of the National Academy of Sciences of the United States of America, v. 107, n. 40, p. 17240-17245, 2010.

ZHANG, L. M.; W., H. H.; P., S. J.; Z., H. J. Ammonia-oxidizing archaea have more important role than ammonia-oxidizing bacteria in ammonia oxidation of strongly acidic soils. The ISME journal, v. 6, p. 1032-1045, 2012.

ZHU, T.; ZHANG, J.; MENG, T.; ZHANG, Y.; YANG, J.; MÜLLER, C.; CAI, Z. Tea plantation destroys soil retention of NO3- and increases N2O emissions in subtropical China. Soil Biology and Biochemistry, v. 73, p. 106-114, 2014. 